\title{
ESTRATIGRAFIA DO SUBGRUPO ITARARÉ NO CENTRO E SUL DO ESTADO DE SÃO PAULO
}

$$
\text { por }
$$

ANTONIO ROBERTO SAAD
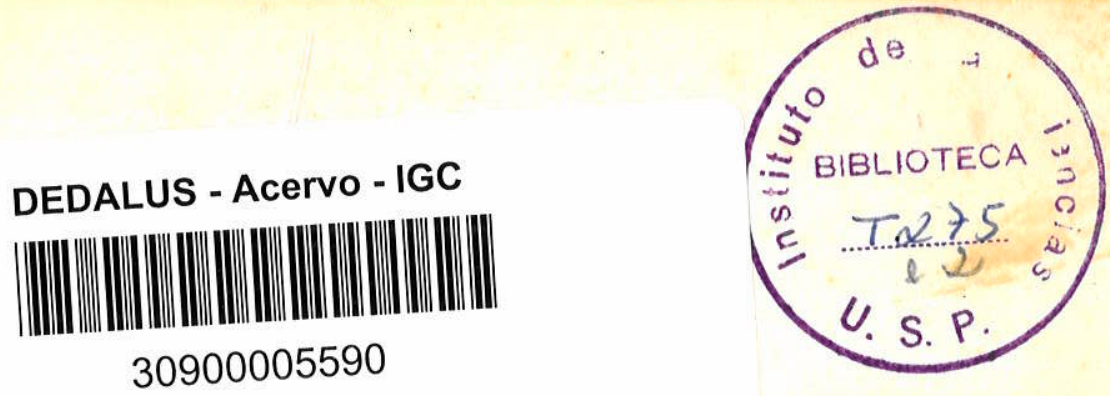

\author{
DISSERTAÇÃO DE MESTRADO \\ APRESENTADA AO INSTITUTO DE \\ GEOCIÊNCIAS DA UNIVERSIDADE DE SÃO PAULO
}

ORIENTADOR: Prof. Dr. A. C. Rocha-Campos 


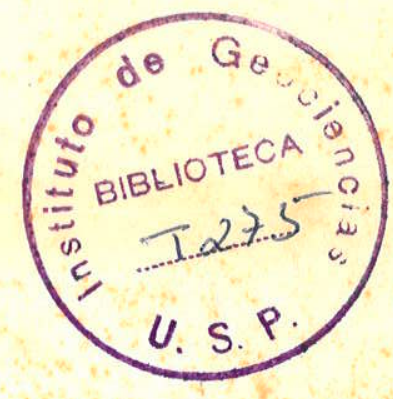

Aos meus pais, ZINA e ANTONIO, e à minha esposa CECILIA MARIA... por existirem, tornam este mundo um lugar melhor do que quando a ele chegaram. 
TRABALHOS DE CAMPO

TRABALHOS DE ESCRITORIO

TRABALHOS DE LABORATORIO

VIA MARECHAL RONDON

VIA CASTELO BRANCO 33

SOROCABA-CERQUILHO (FEPASA)

VIA RAPOSO TAVARES 
5 - ESTRATIGRAFIA 52

GENERALIDADES $\quad 52$

SUBDIVISÃO LITOESTRATIGRÅFICA

B I OESTRATIGRAFIA

Fauna $\quad 58$

$\begin{array}{ll}\text { Flora } & 61\end{array}$

$\begin{array}{ll}\text { Microflora } & 63\end{array}$

$\begin{array}{ll}\text { IDADE } & 68\end{array}$

6 - HISTÓRIA TECTO-SEDIMENTAR 73

7 - ElEMENTOS DE PALEOGEOGRAFIA 79

$\begin{array}{ll}8 \text { - RESUMO } & 91\end{array}$

9 - BIBLIOGRAFIA 99 


\section{ILUSTRAÇOES}

Figura 1 - Localização da ārea de estudo.

Figura 2 - Solução gräfica para cálculo da espessura da camada, em perfil não sobrelevado.

Figura 3 - Representação grāfica da espessura da camada, em perfis sobrelevado e sem sobrele vação.

Figura 4 - Representação gräfica de duas retas perpendiculares, respectivamente, espessura e topo da camada.

Figura 5 - Solução gräfica para cālculo da distância horizontal entre dois pontos situados em cotas diferentes.

Figura 6 - Perfil estratigráfico (em anexo). Explicação: 1: Via Anhanguera; 2: Salto - Rio das Pedras; 3: Via Marechal Rondon; 4:Via Castelo Branco; 5: Sorocaba-Cerquilho (FE PASA); 6: Via Raposo Tavares; 7:Capão-Bonito-Itapetininga; 8: Itararé-Taquarituba;

9: Fazenda Nossa Senhora Aparecida.

Anexa

Figura 7 - Distribuição estratigrāfica dos diamictitos e subdivisão bioestratigräfica do sub grupo Itararé (seg. SANTOS, em preparação).

Figura 8 - Composição das microfloras do Subgrupo It tararē.

Figura 9 - Distribuição dos gêneros de palinomorfos do Subgrupo Itararē.

Figura 10 - Principais elementos tectônicos da Bacia do Paranā durante o Neopaleozóico,na ārea de estudo. 
Figura 11 - Mapa de isōpacas da Formação Itararé e Aquidauana (seg. NORTHFLEET, MEDEIROS \& MUHLMANN, 1969).

Figura 12 - Mapa de desvios da superfície de tendēncia de 3 ọ grau do Subgrupo Itararé (seg. FULFARO, 1971).

Figura 13 - Mapa de porcentagem de diamictito em relação à espessura total do Subgrupo Itararē, em subsuperfície.

Figura 14 - Mapa de resíduo da porcentagem de diamic tito em relação à espessura total do Sub grupo Itararé, em subsuperfície.

Figura 15 - Mapa de porcentagem de areia na Formação Itararē e Aquidauana (seg.NORTHFLEET, ME DEIROS \& MUHLMANN, 1969).

Figura 16 - Mapa de porcentagem de folhelho na Forma ção Itararé e Aquidauana (seg.NORTHFLEET, MEDEIROS \& MÜHLMANN, 1969).

Tabela 1 - Evolução da classificação e nomenclatura do Grupo Tubarão na ārea em estudo. 


\section{1 - INTRODUÇÃO}

Nos ūitimos anos, considerāvel progresso ocorreu no conhecimento da estratigrafia do Grupo Tubarão (Neopaleo zóico), em vārias partes da Bacia do Paraná, através de ma peamento geológico (e.g., ANDRADE \& SOARES, 1970, 1971; SOA RES et al., 1973; VIEIRA, 1973; TOMMASI, 1973), levantamen to de seções e/ou processamento de dados de subsuperfície de poços perfurados pela Petrobrās (Petróleo Brasileiro, S.A.). (e.g., SOARES, 1972; FULFAR0, 1971; LANDIM, 1970, 1972; ME DEIROS \& THOMAZ FILHO, 1973.)

Tais pesquisas permitiram um melhor conhecimento das caracteristicas litológicas regionais do Grupo e sua distribuição areal e estratigráfica, o que tem levado a no vas interpretações sobre relações espaciais entre corpos ro chosos, fácies e ambientes sedimentares, paleogeografia, e elementos tectônicos atuantes durante a sedimentação.

Outros trabalhos de detalhe têm permitido uma me lhor definição da origem e fácies de determinadas litologias do Grupo Tubarão, particularmente, dos diamictitos, do sub grupo Itararē com base na utilização de técnicas diversas (anālise de fácies, sedimentología, microscopia eletrōnica). (e.g., FRAKES \& FIGUEIREDO, 1967; ROCHA-CAMPOS, FARJALLAT \& YOSHIDA, 1969b; LANDIM, 1970.)

Do ponto de vista bioestratigrāfico, dispõe-se, atualmente, de um esquema de subdivisão do Grupo, em base palinológica (DAEMON \& QUADROS, 1970), que oferece apoio ini cial para correlação intrabassinal e datação aproximada das camadas em termos da escala padrão do tempo geológico.

No que diz respeito, especificamente, ao Subgrupo Itararé, unidade inferior do Grupo Tubarão, e que contēm dia mictitos e rochas associadas de origem glacial, muitos aspec 
tos estratigráficos importantes permanecem, contudo, ainda, obscuros, por faltar um arcabouço estratigrāfico regional consistente, que permita entender, adequadamente, as rela ções espaciais entre os corpos litolögicos e a distribuição de muitas feições geológicas e paleontológicas.

Tal arcabouço è de importāncia fundamental e trans cende o âmbito do interesse puramente científico, principal mente, paleoclimático, e que se relaciona com o levantamento das características de uma das épocas glaciais mais extensas e duradouras que afetaram a crosta da Terra. Com efeito, a sequência sedimentar, essencialmente clāstica, do subgrupo Itararé encerra um conjunto de litologias, tambēm, de inte resse económico. Nela são encontradas camadas de carvão que jā foram utilizadas comercialmente no passado (ROCHA-CAMPOS, 1974), possíveis rochas armazenadoras e mesmo geradoras de hidrocarbonetos (MEDEIROS \& THOMAZ FILHO, op. cit.) e litolo gias de interesse tecnológico como materiais de construção (DAMASCENO, 1973).

Além disso o conhecimento da distribuição espacial de possîveis corpos armazenadores de āgua è de suma importān cia, pois sobre a faixa sedimentar ocupada pelo subgrupo,par ticularmente, na margem oriental da Bacia do Paranā, locali zam-se importantes concentrações urbanas que utilizam cada vez mais, āgua subterrânea para o seu abastecimento.

Dentro do contexto acima esboçado, a presente dis sertação apresenta os resultados preliminares de um projeto global, que visa o estudo da estratigrafia da faixa oriental de afloramento do Grupo Tubarão, em especial do Subgrupo I ta rarē, tendo por base o levantamento sistemático de perfis es tratigrāficos perpendiculares à faixa de afloramento (supos tamente, tambēm, grosseiramente, coincidente com a direção geolögica), ao longo de todas as estradas disponiveis que cruzam a extensa faixa sedimentar. 0s perfis, posteriormen te, transformados em seções colunares, seriam correlaciona 
dos entre si, tanto litologicamente, como bioestratigrafica mente, servindo de base para a localização de outras feições sedimentares importantes.

As āreas inicialmente estudadas referem-se às par tes centro e sul do Estado de São Paulo (Figura 1), por cons tituirem as regiões clāssicas e mais significativas de ocor rência do Subgrupo Itararē, tanto em termos de espessura có mo, no que tange, à complexidade da sua histōria sedimentār. Do ponto de vista estratigráfico, abrangem, ainda, a ārea-tị po do Subgrupo Itararé. Por razões de ordem prātica, tive mos que excluir os dados referentes às regiões nordeste do Estado de: São Paulo e sudeste de Minas Gerais, embora tenham sido as mesmas percorridas e examinadas.

0 esquema estratigräfico resultante do levantamen to de oito perfis, aqui apresentado, serve ainda de base pá ra a anālise de alguns aspectos paleontolōgicos, bioestratí gráficos, referentes à distribuição da fauna e flora fósseis do Subgrupo Itararé, que por outro lado, foram utilizadas na solução de problemas de correlação, alēm de permitir avaliar, ainda que brevemente, aspectos da histōria tecto-sedimentar e da paleogeografia do intervalo estratigráfico abrangido.

A dissertação, ora apresentada, complementa-se com a anālise da distribuição, caracterīsticas e provāvel gēnese de diamictitos do Subgrupo Itararē, na mesma ārea, que cons titui tema de dissertação de mestrado elaborada pelo Profes sor Paulo Roberto dos Santos, que colaborou com o presente autor nos trabalhos de campo.

AGRADECIMENTOS. Nesta oportunidade o autor deseja registrar, de uma maneira especial, a mais profunda gratidão ao Prof. Dr. Antonio Carlos Rocha-Campos pela eficaz e segura orientação nesta dissertação, colaborando, com dedi cação, atravēs de profīcuas discussões e sugestões, durante 
- desenvolvimento e composição deste traba1ho; ao Prof. Muri 10 Rodolfo de Lima, ao Geōl. Mitsuro Arai e aos alunos do Ins tituto de Geociências, USP, Srs. Carlos E.S.Pontes, Josē R. Canuto e Rodolfo Dino, pela preparação e identificação das amostras palinolögicas, coletadas por mim; ao Prof. Dr.Ronal do Gama de Carvalho, pelo auxílio no levantamento das seções estratigrāficas; ao Eng. Sērgio Scavone e ao Prof.Dr.Yociteru Hasui, pelas discussões e sugestões prestadas, durante a fa se de elaboração da metodologia utilizada neste trabalho;aos Profs. Drs. Vicente Josē Fulfaro e Kenitiro Suguio, pelas su gestões dadas, sempre que solicitados; ao Sr. Ciro Pereira Borges, pelo auxîlio prestado nos trabalhos de laboratōrio; ao Sr. Clovis Pereira Borges, pelo auxĩlio na confecção dos desenhos, aqui incluidos; ao Sr. Jaime Alves da Silva e equipe, pelos trabalhos grāficos; à Sra. Nair de Campos Louzada e Sr. Josē Ponchirolli, pelo serviço datilogrāfico; à Sra. Cecī lia Maria P.B. Saad, pelo auxílio prestado durante trabalhos de campo e pela compreensão nos muitos momentos de ausēncia do lar; aos meus familiares, pelo estimulo e incentivo; aos amigos e funcionārios do Instituto de Geociēncias da USP, que de uma maneira ou outra, colaboraram na execução deste traba 1ho. Finalmente, ao meu grande amigo e colega Professor Pau 10 Roberto dos Santos, co-autor moral desta dissertação, o meu muito obrigado pela amizade sincera durante esses anos de convĩvio.

Os trabalhos de campo e laboratório aqui relatados foram executados ao abrigo do Convēnio entre a Comissão Nacio nal de Energia Nuclear (CNEN) e Instituto de Geociēncias da Universidade de São Paulo (IG-USP) referente ao Projeto: "Pa drões de sedimentação das rochas clāsticas do Grupo Tubarão da Bacia do Paranā" (TC-19/74).

A atual dissertação constitui parte da contribuição brasileira ao Projeto no 42 do Programa Internacional de Cor relação Geolōgica (PICG), "Upper Paleozoic of South America!", o qual conta com o apoio financeiro do Conselho Nacional de Desenvolvimento Científico e Tecnolōgico ( $C N P q$ ) (Processo $2222.0219 / 75)$. 
$49^{\circ}$

LEGENDA

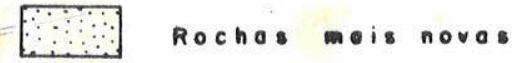

ए Grupe Tuboráo

$++_{+}^{+}$Embosemento

80010

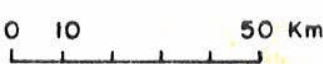

$+$ $48^{\circ}$

$47^{\circ}$

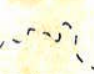
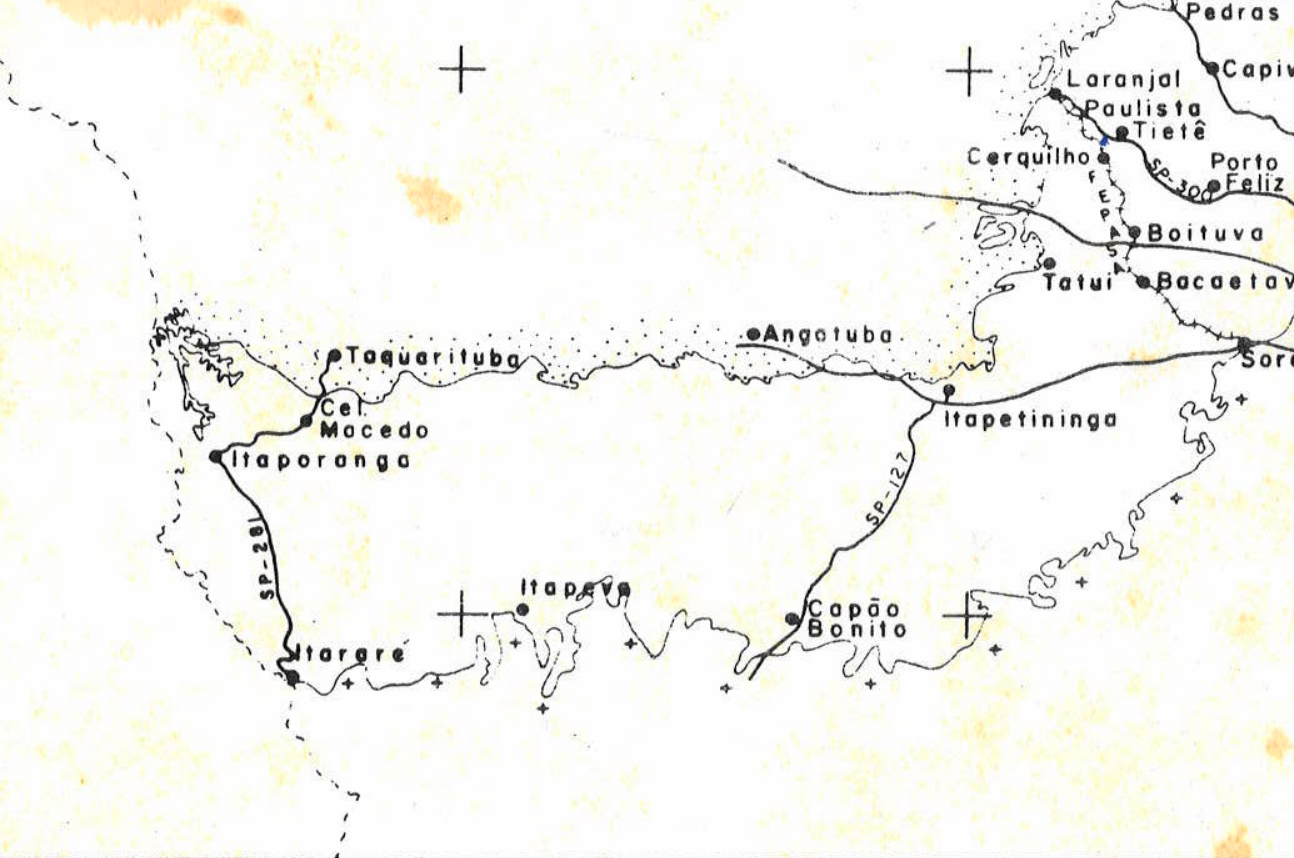

i

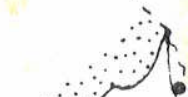

S.Bonedito

dos Areries Mococo

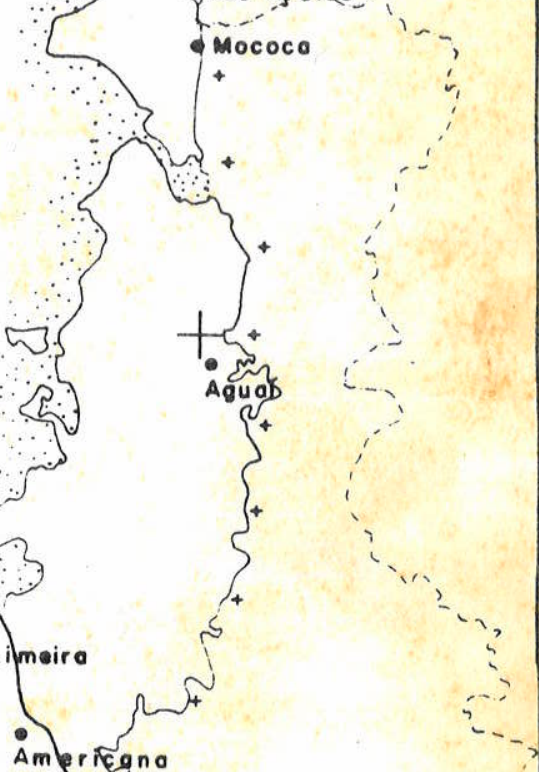

vari

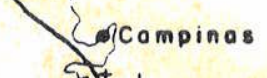

Compinas
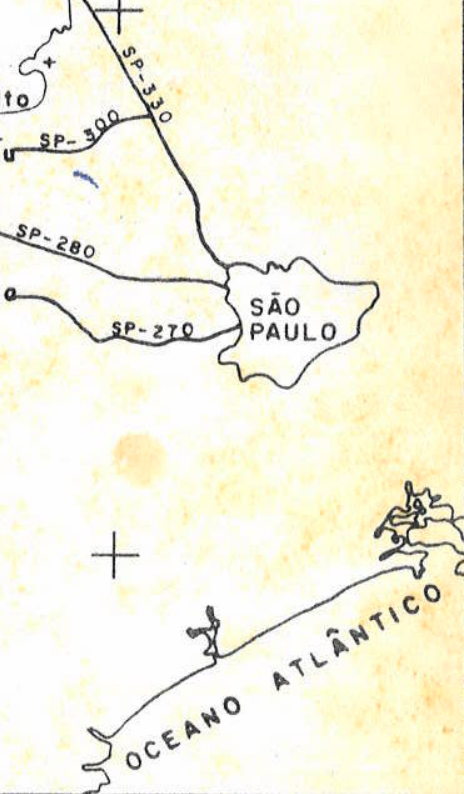

figura 1 - Localização da ärea de estudo. 


\section{2 - TRABALHOS PREVIOS}

Seria, até certo ponto, desnecessārio revisar, no vamente, a literatura anterior relacionada com a estratigra fia do Grupo Tubarão, em geral, e do Subgrupo Itararē, em particular, na ārea abrangida pelo presente estudo. No que tange às referēncias atē 1967, estão elas; na sua quase to talidade, analisadas em ROCHA-CAMPOS (1967). Referir-me-ei, portanto, somente, àquelas de maior pertinēncia para o assun to específico desta dissertação, comentando-as de acordo com a natureza da contribuição oferecida.

Inicialmente, no que tange à subdivisão litoestra tigrāfica do Grupo Tubarão, na ārea paulista da Bacia do Pá ranā, merece referência o trabalho pioneiro de BARBOSA \& ALMEIDA (1949a, b). Com base em reconhecimento estratigrāfí co realizado ao longo de algumas estradas que cortam a faixa de afloramentos e ainda através de anālise do perfil geológi co da sondagem realizada pelo ex-Conselho Nacional de Petrō leo, em Araquā, propuseram estes autores a subdivisão do Grú po Tubarão (então denominado "Sērie") em cinco formações, da base para o topo: Itu, Capivari, Gramadinho, Tietē e Itapeti ninga. As quatro primeiras corresponderiam ao subgrupo It raré da atual concepção, contendo diamictitos de provāvel origem glacial, e a ūltima, subdividida em três membros (Tu pi, Tatuí e Taquaral), correspondendo a seqtềncia pōs-glaciā́. BARBOSA \& GOMES (1958) introduziram, subsequentemente, algu mas modificações na estratigrafia proposta, com base no recó nhecimento de uma discordância regional na base do Membro Taquaral, incluído, destarte, no Grupo Passa Dois sobrejacen te, em razão de seu contato transicional com a Formação Irá ti. Identificaram, ainda, um nível de diamictito ("Tilito Pitanga") no Membro Tupi e elevaram o Membro Elias Fausto,na base da Formação Itu, à categoria de formação. 
A impossibilidade prātica da utilização da subdivi são proposta reconhecida por diversos autores (ROCHA-CAMPOS, 1967; LANDIM, 1970; SOARES, 1972) resultou no seu abandono. ROCHA-CAMPOS (1967) argumentou, adequadamente, com respeito à utilização de uma subdivisão provisōria do Grupo Tubarão em uma unidade inferior, portadorade diamictitos e rochas as sociadas de provāvel origem glacial, denominada subgrupo Ita rarē e outra sobrejacente, mas desprovida de evidências de origem glacial (sequência pós-glacial), para a qual sugeriu a denominação de Formação Tatuî, prioritária em relação à Formação Itapetininga, jā mencionada.

0 exame da literatura posterior a 1967 evidencia di ferenças na utilização da nomenclatura do Grupo Tubarão, na ārea abrangida pelo presente estudo, por parte dos diversos autores. A Tabela 1 sintetiza algumas das diversas classifi cações e nomenclaturas aparecidas até o presente.

No atual trabalho, preferi manter a classificaçãoe nomenclatura proposta por PETRI (1964) e ROCHA-CAMPOS (1967), denominando as duas subdivisões do Grupo Tubarão, respectiva mente, Subgrupo Itararē e Formação Tatuĩ. No primeiro caso, os resultados deste projeto, e de pesquisas efetuadas por ou tros autores demonstram ser ainda conveniente manter a cate goria de Subgrupo para a sequência Itararē, tendo em vista a possibilidade de sua subdivisão litoestratigrāfica e a con saguinidade estreita entre os elementos que a compõe. Quan to à Formação Tatuî, não discutida em detalhe na presente dis sertação, considero ter a mesma, no geral, um conjunto de caracterīsticas que permite individualizā-la e diferenciā-la, adequadamente, da unidade equivalente da parte sul da Bacia (Subgrupo Guatā).

Com respeito à fācies e paleogeografia do Subgrupo Itararē, è fundamental o trabalho de FRAKES \& CROWELL(1969), que apresentaram uma sīntese sobre a glaciação neopaleozōica da América do Sul, inclusive Bacia do Paranā. ROCHA-CAMPOS, 


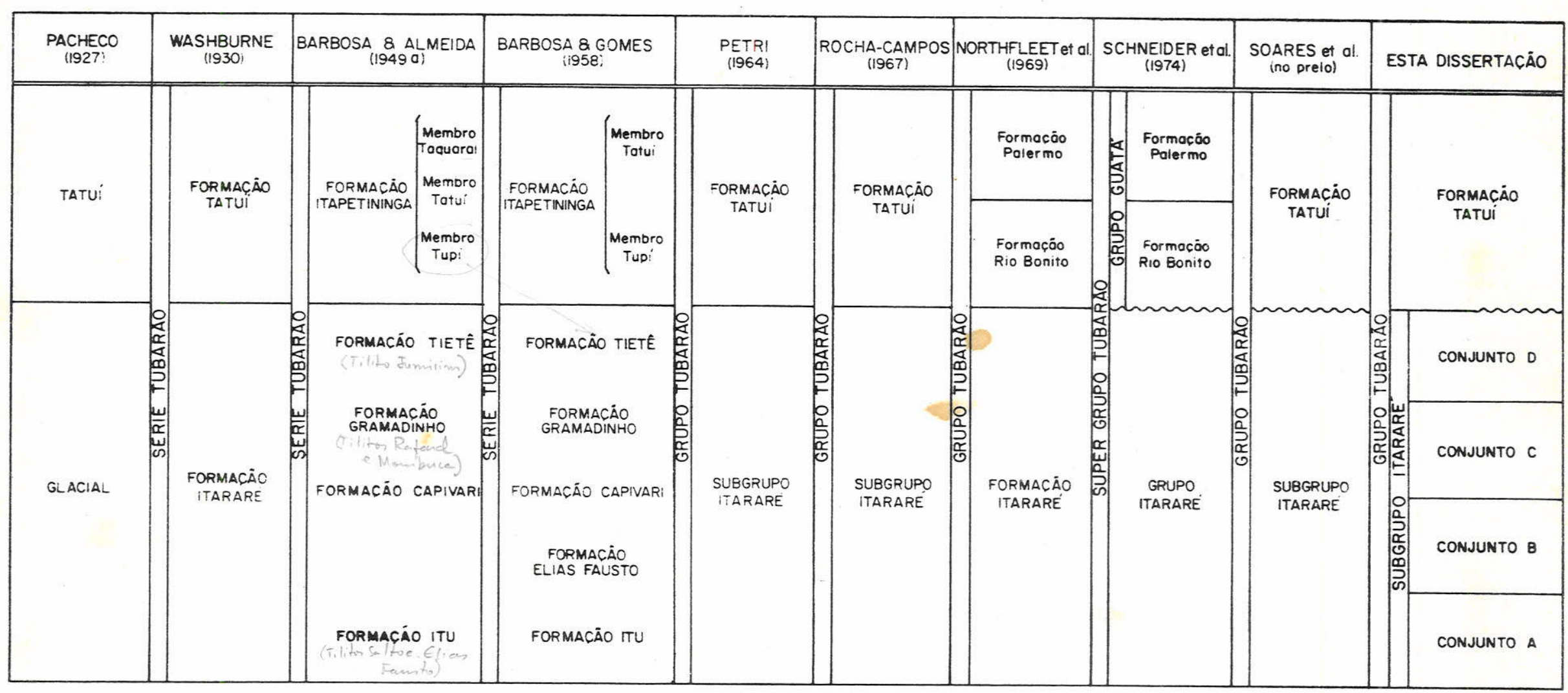

Tabela 1 - Evolução da classificação e nomenclatura do Grupo Tubarão na ärea ell estudo. 
FARJALLAT \& YOSHIDA (1968, 1969a), ROCHA-CAMPOS et al., (1976 e no prelo) e FRAKES, FIGUEIREDO \& FULFARO (1968) descreve ram vārios tipos de estruturas glaciais ocorrentes no subgrú po Itararē, no Estado de São Paulo, relevantes para a identi ficação da origem dos diamictitos e rochas associadas e a determinação da direção de deslocamento das geleiras neopa leozōicas, na parte norte da Bacia do Paranā.

Outras contribuições de importāncia para o enten dimento da origem e fácies dos diamictitos e outras litolo gias do Subgrupo Itararē são as de LANDIM (1970), LANDIM \& BARROS (1972) e FULFARO \& LANDIM (1976), que as analisaram atravēs de tēcnicas sedimentolōgicas e estatīsticas.

ROCHA-CAMPOS, FARJALLAT \& YOSHIDA (1969b) propuze ram, tambēm, um esquema paleogeogrāfico da Bacia do Paranā, durante a deposição do Subgrupo Itararé, com base em dados direcionais e distribuição de fācies sedimentares. Outra re construção foi proposta, mais recentemente, por FRAKES \& CROWELL (1972), com base, essencialmente, nos mesmos elemen tos.

FULFARO (1971) e LANDIM (1972) e FULFARO \& LANDIM (1976) forneceram valiosos dados para o entendimento da his tōria tecto-sedimentar e da paleogeografia da Bacia do Para nā, inclusive da ārea em foco, com base na aplicação da tēć nica de anālise de superfícies de tendēncia ("trend-surface analysis"), a dados de espessura do subgrupo Itararē.

SOARES (1972) retomou o problema do limite supe rior do Subgrupo Itararē, reconhecendo a existēncia de uma discordância erosiva regional separando essa unidade da for mação Tatuī (pōs-glacial), alēm de distinguir outras discór dāncias de menor monta dentro da Formação Tatuí.

A subdivisão bioestratigrāfica da sequência neopa leozōica da Bacia do Paranā, em base palinolōgica, proposta por DAEMON \& QUADROS (1970) ofereceu, pela primeira vez, um 
arcabouço bioestratigrāfico ūtil para o entendimento da hís tōria geológica do Grupo Tubarão. Esses autores utilizaram, principalmente, amostras de subsuperfície, mas processaram tambēm algumas amostras de afloramentos da ārea paulista.

Informações sobre a paleontologia do Subgrupo Ita raré foram fornecidas por BOCHA-CAMPOS (1970), que revisou os moluscos e braquiōpodes da fauna de Capivari, MILLAN (1972, 1974, 1975) e DOLIANITI \& MILLAN (1972), respectivamente, que descreveram e identificaram tafofloras da parte média e supe rior do Subgrupo Itararé, no Estado de São Paulo, em Monte Mōr e Cerquilho. A sucessão estratigrāfica de megafloras fós seis neopaleozóicas da Bacia do Paranā, proposta por ROSLER (1973) abrange, tambēm, as floras fósseis do subgrupo Itara rá. KEMP (1973) processou algumas amostras de diamictitos e outras litologias do Subgrupo Itararé, no Estado de São Paulo, descrevendo a microflora e comentando acerca do seu significado para a cronologia e correlação intercontinental. LIMA et al. (no prelo) descreveram,pela primeira vez, uma mi crofauna de foraminíferos arenáceos associados com coprōi tos do tipo "enterospira", obtidos de concreções da parte média do Subgrupo Itararé.

PETRI \& FULFARO (1967) mapearam sedimentos perten centes ao Subgrupo Itararē, na ārea de Itapeva, distinguindo-os dos da Formação Furnas. Reconheceram, então, um evento tectônico que precedeu a sedimentação do Grupo Tubarão.

Mais recentemente, SOARES et al. (1973) e SOARES et al. (no prelo) cartografaram geologicamente o Subgrupo Itararē da parte norte e central do Estado de São Paulo. SOA RES et al. (no prelo), com base no mapeamento e levantamento estratigrāfico acima mencionados, identificaram quatro asso ciações litolōgicas na parte superior do Subgrupo Itararé e reconheceram oito fäcies distintas na Formação Tatuí, discu tindo a sua provāvel gênese e pałeogeografia. 
Referências breves à estratigrafia e outros aspec tos da geologia do Subgrupo Itararé, aparecem, ainda, em es tudos de âmbito mais geral de revisão da Bacia do Paranā,tais como os de NORTHFLEET, MEDEIROS \& MÜHLMANN (1969). 


\section{3 - METODOLOGIA}

INTRODUÇÃO. Como jā mencionado anteriormente, a pre sente pesquisa baseou-se, fundamentalmente, no levantamento de perfis geológicos, ao longo de estradas que cruzam a faixa de afloramento do Grupo Tubarão, das regiões centro e sul do Estado de São Paulo, acompanhado de registro das litologias, suas relações estratigráficas, coleta de amostras para anālises sedimentolōgicas e palinolōgicas e, embora ainda subsidiariamente, do exame e identificação de estruturas sedimentares sin-e epigenēticas. Posteriormente, todo o registro obtido ao longo dos perfis foi manipulado para apresenta ção sob a forma de seções colunares, que correlacionadas entre si, oferecessem um panorama geral da estratigrafia do Subgrupo Itararē na ārea de pesquisa.

As soluções adotadas para obtenção dos resultados contēm algumas limitações inerentes às circunstâncias geológicas e meios disponíveis para a execução dos levantamentos.

Assim, considerou-se que a margem oriental da atual faixa de afloramento, obviamente erosiva, ē, grosseiramente, paralela às direções geológicas das camadas. Desse modo, os mergulhos regionais foram considerados perpendiculares à mes ma. As variações gerais de direções das estradas que cruzam a faixa de afloramento corresponderiam, assim, a variações da direção de cada perfil, em relação à direção geolōgica, re presentada pela tangente ao ponto inicial e final de cada perfil medido. Felizmente, dentro do contexto acima esboçado, a maioria das estradas disponỉveis são, realmente, grosseira mente, perpendiculares, ou bastante oblīquas à faixa de aflo ramento, o que minimisa as possīveis distorções.

Outra limitação decorre de condições topográficas e geológicas (relevo suave e valores baixos do ângulo de mergu 
Tho regional mēdio) do Grupo Tubarão, na ārea pesquisada, do que resultam as grandes distâncias que separam topo e base das sequēncias medidas, que variam de 50-60 km. 0 empilhamen to resultante da representação sob forma de seções colunares $\bar{e}$, obviamente, artificial e nele, provavelmente, superpõem-se litologias e fácies deslocadas, geograficamente, ao longo do mergulho, de atē dezenas de quilômetros. A histōria geolōgica resultante representa, pois, uma média ou um conjunto de situações, que embora representadas na vertical, não ocorreram no mesmo lugar.

Värios problemas tiveram, ainda, que ser resolvidos, preliminarmente, antes de iniciada as fases de trabalhos de campo e de escritōrio.

Estes diziam respeito aos seguintes itens principais: a) escolha dos perfis a serem levantados; b)estudo do controle geológico; c) escolha das escalas para representação dos perfis topográficos e das seções colunares resultantes; e d) cālculo das espessuras das camadas, em perfis topo gräficos sobrelevados.

0 primeiro item foi resolvido atravēs do exame preliminar da literatura, utilização da experiência prēvia e viagens de reconhecimento.

0 controle geolōgico, especialmente estratigräfico e tectônico, precedeu e sucedeu o levantamento das seções. Inicialmente, foi executado atravēs da consulta da literatura existente, em especial mapas geológicos, exame de fotos aéreas e durante a própria execução dos trabalhos de campo. Posteriormente, por ocasião da construção das seções colunares, atravēs de correlação litolögica e controle bioestratigrāfico, principalmente, com base palinolōgica.

Outro problema geológico importante que teve de ser resolvido, refere-se ao mergulho regional das camadas examinadas. Inicialmente, vārias tentativas foram feitas para a 
determinação dos valores do mergulho, ao longo das seções le vantadas. Um dos mētodos utilizados foi o dos três pontos em afloramentos, com o uso do teodolito. Para tal,esses deveriam ocorrer em ambos os lados da estrada, conter níveis ou camadas-guias facilmente reconhecīveis e possuir dimensões que permitissem um espaçamento conveniente entre os pontos visados. Os resultados obtidos variaram em torno de $1^{0}$ a $3^{0}$. Poucas exposições, contudo, mostraram-se adequadas para o le vantamento e o mētodo teve, portanto, que ser abandonado,ten do em vista, ainda, refletirem os resultados condições muito locais.

Por fim, decidi-me valer do seguinte expediente:conhecendo as espessuras locais em vārios perfis levantados e usando o método da tentativa e erro,testei diferentes valores possīveis de āngulos de mergulho, atē encontrar um que satisfizesse aos dados de que dispunha. 0 valor encontrado foi, constantemente, o de $1^{0}$ para o mergulho regional.Alguns perfis foram construĩdos e verificou-se que as espessuras re sultantes estavam de acordo com os dados disponiveis na lite ratura. Embora, tendo em conta que o ângulo de mergulho pode variar, localmente, como jā foi comentado, acredito que o va lor utilizado representa a média geral dos valores existentes.

Quanto às escalas a serem utilizadas na construção do perfil topogräfico, apōs vārias tentativas e observações de campo, as que se mostraram mais convenientes foram as de 1:20 000 na horizontal e de 1:1 000 na vertical. A primeira, justifica-se pelo fato de que se fosse adotada una escala ma ior, os perfis tornar-se-iam inadequados para trabalhos de escritōrio, devido ao seu tamanho. Por outro lado, utilizando-se escalas menores, muitas das relações litolōgicas ficariam difíceis de serem estabelecidas e compreendidas.com relação à escala vertical, chegou-se à conclusão de que a mais operacional seria a de $1: 1000$, pois as principais estrutu- 
ras sedimentares presentes nos corpos litolögicos eram da or dem de metros. Decidiu-se que esta seria, tambēm, a escala a ser utilizada na apresentação das seções colunares, por ser a mais compatível com o carāter regional do presente traba1ho.

Para o cālculo das espessuras das vārias unidades litolögicas que compõem os perfis colunares utiliza-se, normalmente, um método gräfico, em que se considera a espessura da camada como correspondente ao comprimento do segmento per pendicular, entre o topo e a base da unidade medida (Figura 2). Este método, entretanto, ē inexato para perfis sobreleva dos, uma vez que para estes, a distāncia real entre topo e base da camada não ē mais medida pelo segmento perpendicular entre elas, conforme indica a Figura 3.

Foi, portanto, necessārio desenvolver um mētodo ana lítico preciso para calcular a espessura exata, a partir dos dados disponiveis nos perfis sobrelevados.

Tal método consiste, basicamente, no cālculo das co ordenadas $x$ e $y$, de uma das extremidades do segmento perpendicular (aquela sobre o topo da camada), uma vez que a outra extremidade é colocada na origem do sistema cartesiano(coordenadas 0,0$)$. Assim, a espessura pode ser determinada, da geo metria analitica, pela förmula $e=\sqrt{x^{2}+y^{2}}$. Na Figura $2, \overline{A C}$ representa a espessura da camada e os pontos A e C são base (coordenadas 0,0 ) e topo (coordenadas $x, y)$, respectivamente.

Para cālculo das coordenadas $x$ e y acima, observese a Figura 4.

Da geometria analitica, tem-se que as equações das retas 1 e 2 são:

$$
\begin{aligned}
& \text { equação da reta } 1: \quad x+m y=0 \\
& \text { equação da reta } 2: \quad y=m x+b \\
& \text { onde, } m=(-) \text { tangente do ângulo de merguilho da ca- }
\end{aligned}
$$




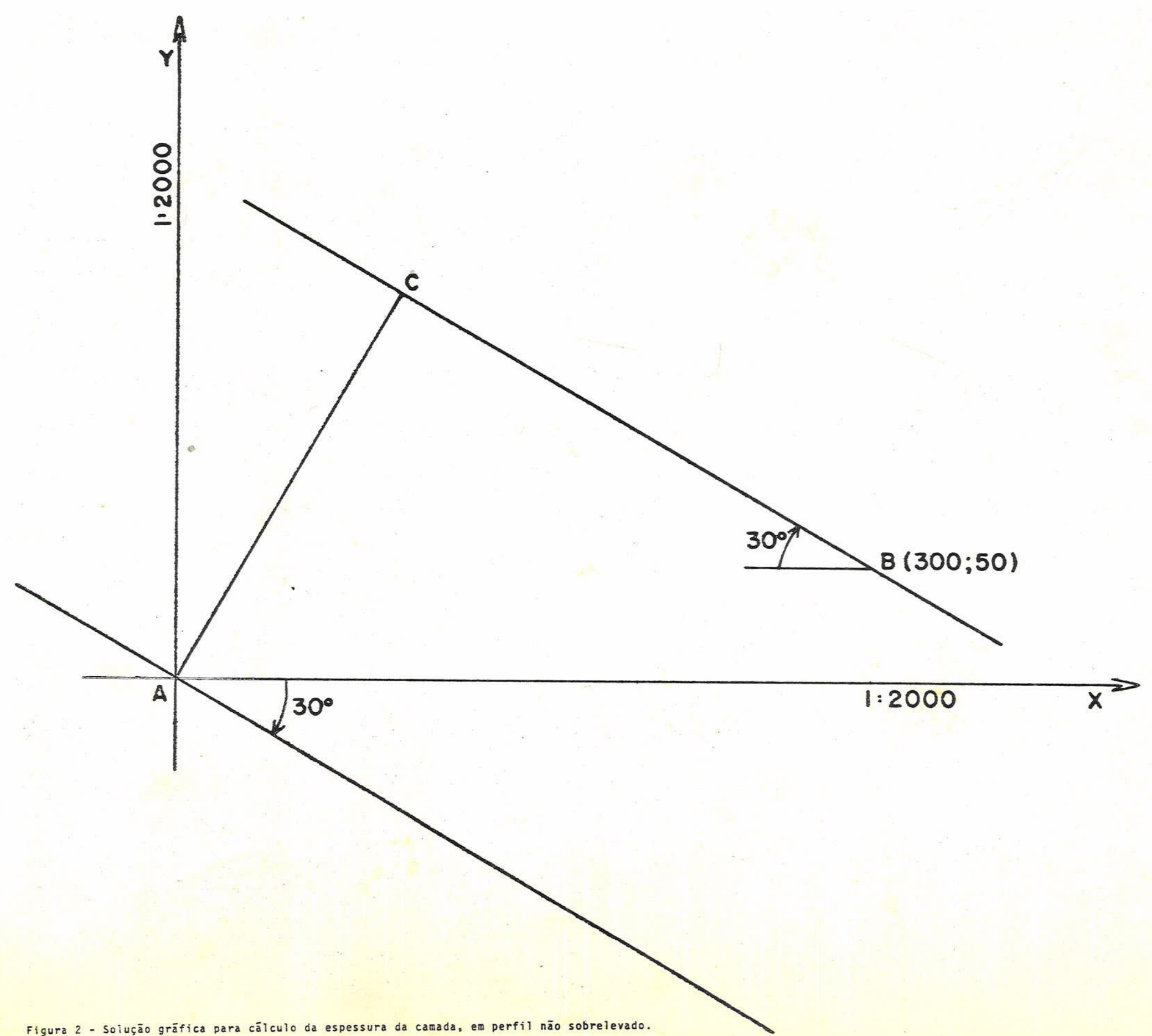




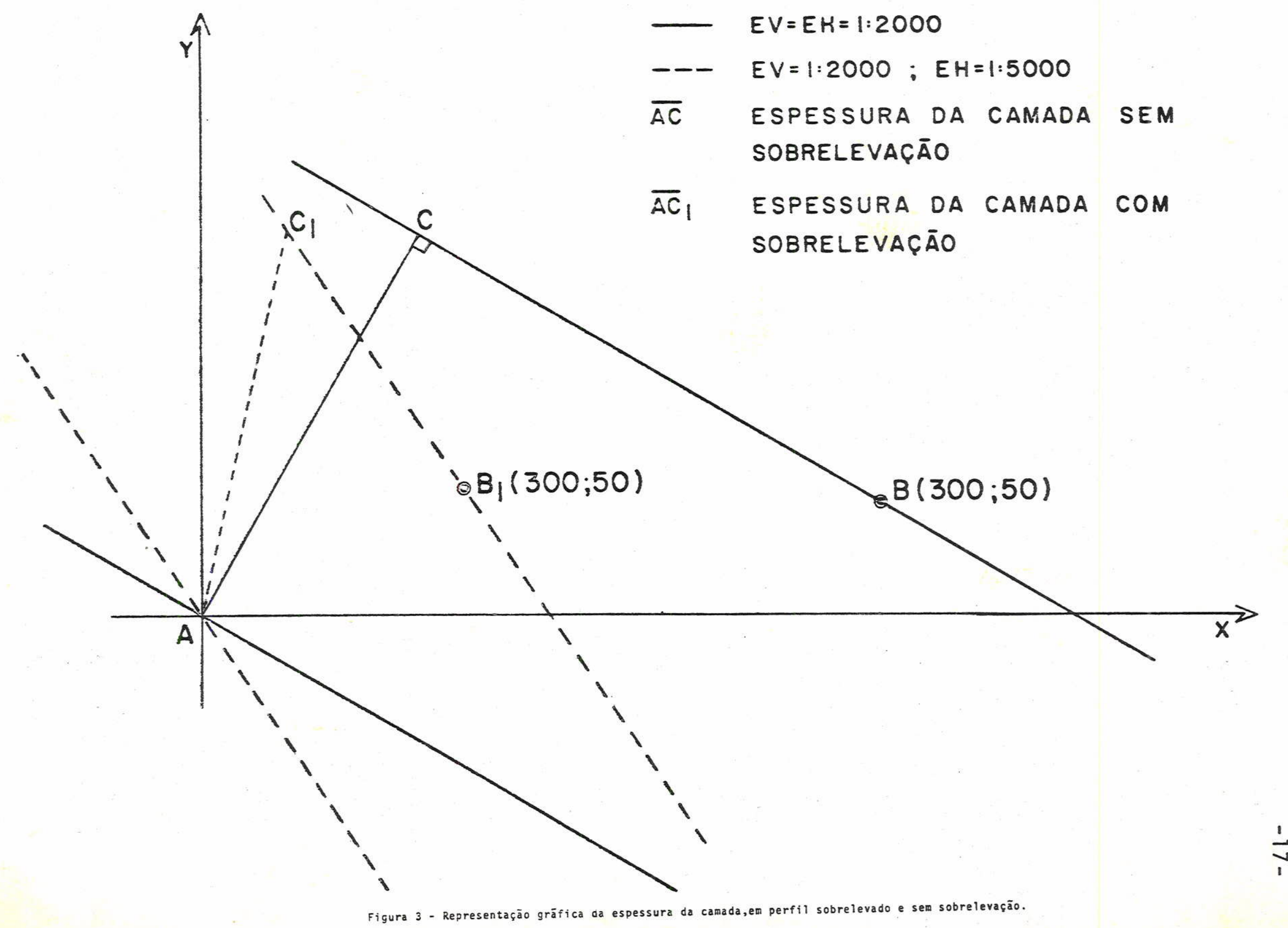




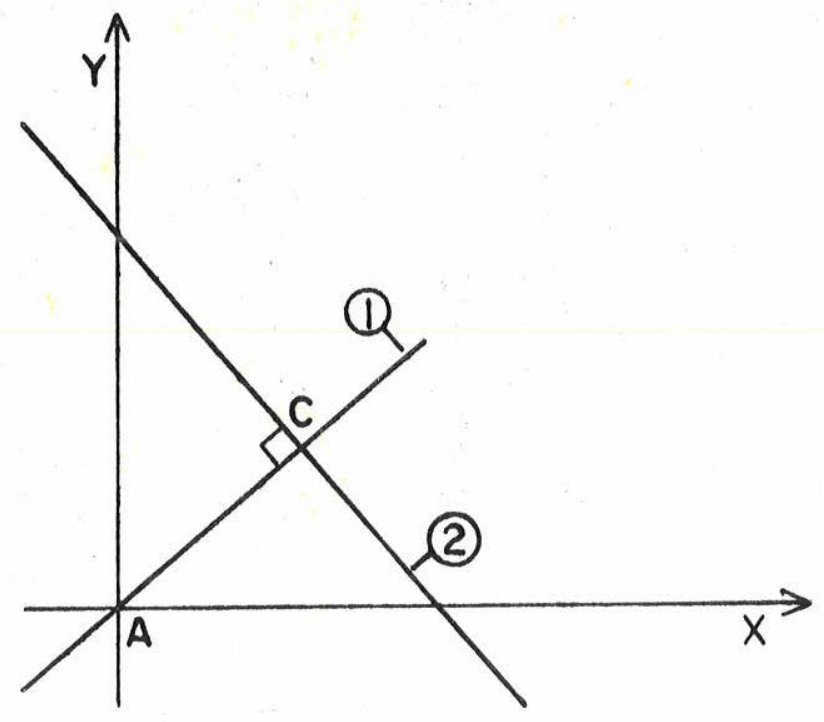

Figura 4. Representação de duas retas perpen diculares, respectivamente, espessura e topo da camada.

mada e $b=$ constante real, função da posição da reta. Destas equações resulta que:

$$
x=\frac{-m b}{1+m^{2}} \quad \text { e } \quad y=\frac{b}{1+m^{2}}
$$

Desde que se conheçam $\underline{b}$ e $\underline{m}$, pode-se facilmente, de terminar o valor da espessura, aplicando a fórmula acima men cionada.

A fim de ilustrar o método descrito, observa-se a Figura 2. Pelo método gräfico convencional o valor obtido pa ra a espessura da camada é igual de 193 metros. No cālculo da espessura, pelo método desenvolvido nesta dissertação, calcula-se, primeiramente, os valores de $\underline{m}$ e $\underline{b}$. No caso presente,

$$
\begin{aligned}
& m=-\operatorname{tg} 30^{0}=-0,577 \\
& b=y-m x=50-(-0,577) \cdot 300=223,10 \mathrm{~m} \\
& x c=\frac{-m b}{1+m^{2}}=\frac{-(-0,577) \cdot 223,10 \mathrm{~m}}{1+(-0,577)^{2}}=96,58 \mathrm{~m} \\
& y c=\frac{b}{1+m^{2}}=\frac{223,10 \mathrm{~m}}{1+(-0,577)^{2}}=167,38 \mathrm{~m}
\end{aligned}
$$

Portanto, $e=\sqrt{x^{2}+y^{2}}=\sqrt{(96,58)^{2}+(167,38 m)^{2}}=193,24 \mathrm{~m}$. 
Em muitos casos, o ângulo de merguiho $(\alpha)$ é pequeno (tg $\alpha \cong \alpha)$. Aplicando-se tal igualdade nas fórmulas acima tem-se :

$$
\begin{aligned}
& m=-\operatorname{tg} \alpha \cong-\alpha\left(a \text { tê } 5^{0}\right) \\
& x=\frac{-m b}{1+m^{2}} \cong-m b \\
& y=\frac{b}{1+m^{2}} \cong b
\end{aligned}
$$

Portanto, $e=\sqrt{b^{2}+m^{2} b^{2}}=b \sqrt{T+m^{2}} \cong b$.

Conclui-se, portanto, que para perfis sobrelevados, com àngulo de mergulho pequeno, a espessura è igual à ordena da do ponto em que o topo da camada corta o eixo dos y, sendo, facilmente, obtida do grāfico do perfil topogrāfico, qualquer que seja a sobrelevação.

TRABALHOS DE CAMPO. A escolha do procedimento de campo a ser utilizado decorreu das condições acima apontadas, da precisão desejada e da solução dos problemas de transformação da medida dos perfis em seções colunares.

Estes iniciaram-se atravēs de reconhecimento geral da seção a ser levantada. A etapa seguinte consistiu de indi vidualização, numeração, descrição, medidas de distāncia e altimetria dos corpos litolögicos. Alëm das litologias, foram identificadas e/ou medidas as principais estruturas sedimentares presentes.

Durante esta fase, foram coletadas amostras para anālises sedimentolōgicas e palinolögicas. A coleta para palinologia teve como critērio de amostragem a cor e o grau de alteração dos sedimentos, tendo sido dada preferência a amostras de tonalidades cinzas, que não exibissem evidências de oxidação.

Apōs a individualização dos pontos de observação e 
descrição dos corpos rochosos, passou-se a marcação, por piquetes ou tinta, das vārias unidades que compunham o perfil, ao longo da estrada examinada. A seguir, foram feitas as medidas altimētricas dos piquetes e pontos topogrāficos, assim como a verificação, por odōmetro, das suas distâncias. Utili zou-se nesta fase, um altímetro tipo "American Paulin System", com intervalos de medidas de dois metros. Um segundo altỉmetro, do mesmo tipo e características, aferido,juntamen te com o primeiro, em pontos topogräficos de cotas altimétri cas conhecidas, ficou baseado no meio da seção, para elabora ção da curva de calibração.

TRABALHOS DE ESCRITORIO. Os trabalhos de escritōrio consistiram na transformação dos dados obtidos durante a fase anterior em seções colunares. Para tal, algumas correções dos dados levantados fizeram-se necessārios. Estas podem ser sintetizadas da seguinte forma:

a) correção dos dados de altimetria, utilizando-se a curva de calibração;

b) cālculo da distância horizontal entre os pontos;

Quando, de um ponto para outro, houve diferença de cota, foi necessário o cālculo da distāncia, na horizontal, que seria colocada no perfil topográfico a ser construido(Fi gura 5). Este cälculo foi feito atravēs da seguinte fórmula:

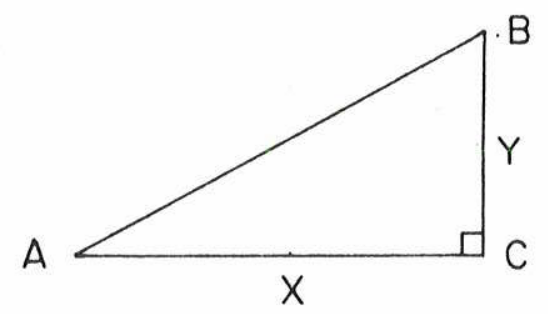

Figura 5

$$
\begin{aligned}
\overline{\mathrm{AB}}^{2}= & \bar{Y}^{2}+\bar{X}^{2}, \text { onde } \\
\overline{\mathrm{AB}}= & \text { distāncia em metros percor } \\
& \text { rida no terreno entre dois } \\
& \text { pontos. } \\
Y= & \operatorname{cota} \text { de } B-\operatorname{cota} \text { de } A \\
\bar{X}= & \text { distância em metros na ho- } \\
& \text { rizontal. }
\end{aligned}
$$

Portanto, $\bar{X}=\sqrt{A B^{2}-Y^{2}}$. 
c) correção do ângulo de mergulho;

Pelo fato das estradas levantadas não serem, exatamente, perpendiculares à direção das camadas, utilizou-se o método descrito por SMITH (1925), para o cālculo do mergulho aparente, segundo a förmula:

$$
\operatorname{Cotg} a=\frac{\operatorname{Cotg} c}{\operatorname{Sen} \alpha}, \quad \text { onde, }
$$

$a=$ àngulo de mergulho aparente

$c=$ àngulo de meraulho real

$\alpha=$ ângulo formado entre a direção geológica e a direção do perfil

vado:

d) cālculo do àngulo de mergulho aparente sobrele-

$$
\operatorname{tg} b=n \operatorname{tg} a, \quad \text { onde, }
$$

$b=$ mergulho aparente sobrelevado.

$\mathrm{n}=$ sobrelevação.

$\mathrm{a}=$ mergulho aparente.

TRABALHOS DE LABORATORIO. Os trabalhos de laboratō rio restringiram-se à preparação palinológica das amostras coletadas.

As preparações palinológicas foram realizadas segundo as técnicas comumente empregadas, que se encontram des critas em FAEGRI \& IVERSEN (1966).

Os espécimes identificados, preliminarmente, têm a sua posição nas lâminas marcadas segundo coordenadas para mi croscōpio Carl Zeiss "Large Universaz", do Departamento de Pa leontologia e Estratigrafia do Instituto de Geociências.

As lâminas estão depositadas na Coleção de Pesquisa (GP/4E) do DPE, sob os nümeros $1-3 ; 6-7 ; 10 ; 13-25 ; 48-170$. Em todos os casos em que foi possível( $\geqslant 100$ espécimes identificā veis/lâmina), procedeu-se a determinação percentual dos principais tipos de esporos e polens presentes nas amostras. 


\section{4 - DESCRIÇÃO DAS SEÇÕES ESTUDAdAS}

TERMOS LITOLOGICOS EMPREGADOS. O Subgrupo Itara rēen na ārea estudada, abrange um conjunto de rochas sedimeñ tares de natureza, essencialmente, clästica (ROCHA-CAMPOS, 1967; LANDIM, 1970). Rochas de origem quīmica (calcārios) são de ocorrência muito rara e as de natureza organōgena, tais como carvão, embora participem do Subgrupo, não foram identificadas ao longo das seções examinadas.

Apōs reconhecimento megascōpico preliminar das $1 \underline{i}$ tologias do Subgrupo Itararé em afloramentos, procurou-se selecionar a terminologia mais adequada para os diferentes tipos de rochas clästicas encontradas, no sentido de obter uma razoāvel consistēncia e homogeneidade nas descrições das caracteristicas físicas da sequéncia estudada. Apresen to, pois, abaixo a lista de termos utilizados e as respecti vas conceituações.

Diamictito: Corresponde ao equivalente litificado do, diamicton. Este por sua vez, è um depösito clästico,ter rïgeno, não calcārio, inconsolidado, mal selecionado, com posto de areia e/ou partículas maiores, dispersas em uma ma tria mais fina. Nesta definição não estão englobados grau vacas e arenitos similares (FLINT, SANDERS \& RODGERS, 1960).

Arenito: A classificação granulomētrica aproxima da dos arenitos examinados foi feita atravēs da comparação com amostras de grãos de areias previamente peneiradas, acon dicionados em tabela plastificada. A escala granulomētricá utilizada foi a de WENTWORTH (1922). Os demais parämetros texturais analisados, como seleção, composição mineralögica e maturidade, foram avaliados, grosseiramente, com auxilio de lupa de mão e, por isso, tiveram seus conceitos simplifi cados. (luanto à seleção, por exemplo, utilizei, somente, 
os indices pobremente, medianamente e bem selecionados. Na descrição da composição mineralógica levou-se em conta, ape nas, a presença ou ausencia de quartzo, feldspato e mica na amostra, enquanto que o grau de maturidade composicional (S $\underline{U}$ GUI0, 1973) baseou-se na porcentagem de grãos de quartzo nas amostras examinadas.

Ritmito: Empregou-se este termo para nomear rochas que exibem alternância cíclica de litologias de diferentes granulometrias dentro das seguintes condições: a) a lâmina ( $\leqslant 1 \mathrm{~cm}$ ) ou camada (> $1 \mathrm{~cm}$ ), correspondente à fração mais grossa do par litológico, é mais espessa que a unidade de granulação mais fina; b) a espessura do par considerado não ultrapassa alguns decīmetros; e c) cada componente do par $1 \underline{i}$ tológico tem razoável continuidade lateral em afloramento, não sendo,obviamente, lenticular.

Siltito: Designa este termo rochas em que se pode perceber o predominio de partículas de tamanho silte sobre as demais.

Argilito: Corresponde a rochas em que se nota pre dominio de partículas de tamanho argila sobre os outros ter mos.

Lamito: Desígna uma rocha de carāter, essencialmen te, maciço, constituída de mistura de silte e argila, em pró porções variáveis (INGRAM, 1953 in PETTIJOHN, 1957).

Folhelho: Foi empregado para nomear siltitos, argi litos e lamitos que apresentam fissilidade nítida.

VIA ANHANGUera $(S P-300)$. A seção examinada ao lon go da Via Anhanguera, entre os km 90 (Campinas) e 154 (Lime ra) (Figura 1), "mostrou-se, infelizmente, muito pobre emaflo ramentos. Alēm da ausência de sedimentos atribuĩveis à For mação Tatuĩ, somente no terço superior da seção é que as exposições tornam-se mais frequentes. Por esse motivo, tanto 
o contato inferior do Subgrupo Itararé, com o embasamento cristalino (Prē-Cambriano), como o superior, localmente, com rochas bāsicas (Eocretāceo), não são diretamente observāveis.

A espessura medida do Subgrupo Itararē na ārea, pe 1 a metodologia utilizada, foi de $717 \mathrm{~m}$. As principais 1 ito logias que compõem o Subgrupo são: siltitos, arenitos, diamic titos e ritmitos. Subsidiariamente, ainda, aparecem argili to e folhelho. A seção mostrada na Figura 6 exibe a sequén cia litológica verificada.

Subgrupo Itararé. Siltitos perfazem, pelo menos, $40 \%$ da espessura aflorante do Subgrupo. São, geralmente, ama relo-avermelhados, argilosos, maciços ou estratificados com camadas de arenito fino. Suas espessuras variam de poucos a dezenas de metros. Quando associados a diamictitos (subja zendo ou superpondo-se, em contatos bruscos) podem conter microclastos dispersos na matriz. Os contatos com outros ti pos de litologia, subjacentes ou superpostas, são, tambēm, normalmente bruscos.

Os siltitos constituem litofácies comumente asso ciada às ocorrēncias de fósseis marinhos no subgrupo Itararē, na Bacia do Paranā, em geral (ROCHA-CAMPOS, 1967), e na ārea de estudo, em particular (SANTOS, em preparação). Na seção estudada, uma nova assemblēia fossilîfera constituīda de bi valves, foi localizada pelo geōlogo Seirin Shimabukuro. Den tre as espēcies presentes, Phestia, Nuculopsis e Edmondia (?), pelo menos, a primeira ocorre, tambēm, nos siltitos mari nhos de Capivari, mais ao sul (ROCHA-CAMPOS \& ROSLER, no pre 10).

Quanto aos arenitos, estes formam corpos de dife rentes formas e dimensões, podendo aparecer intercalados nos siltitos, como jā vimos, nos diamictitos e independentemente. Descreverei, a seguir, somente, os que ocorrem isolados, sen do os demais tratados quando da abordagem dos diamictitos. 
As espessuras dos corpos arenosos, frequentemente, atingem poucas dezenas de metros. A coloração ē, geralmente, amarelada, localmente avermelhada. Granulometricamente, va riam de finos a grossos, predominando os de granulação média. Sua seleção varia de mediana a pobre. Somente em um caso (ponto 92), um corpo de arenito interpretado por BJURNBERG, LANDIM \& GANDOLFI (1965) como eōlico, mostrou boa seleção. A presença de quantidades significativas de feldspatos na maio ria dos arenitos examinados, evidencia a sua imaturidade com posicional.

Os arenitos podem ser maciços ou estratificados. A estratificação pode ser plano-paralela ou cruzada (tabular e acanalada) (POTTER \& PETTIJOHN, 1963), de grande porte (REINECK \& SINGH, 1973), as quais estão relacionadas a cor pos em forma de canais, com a parte superior truncada por erosão. Os contatos verificados com as litologias sobre e sotopostas são bruscos.

os diamictitos, de maneira semelhante aos arenitos, formam corpos de diferentes formas e espessuras. 0 nümero de níveis de diamictitos é apreciāvel e, pelo menos, sete ou oito horizontes puderam ser reconhecidos. Suas espessuras são, geralmente, da ordem de metros $(2-3 \mathrm{~m})$. Contudo,alguns corpos maiores são encontrados na parte média da seção. Os contatos, superior e inferior, com outras litologias são, tambēm, bruscos.

Anāiises granulométricas mostraram que a matriz dos diamictitos é,em sua maioria, de composição silto-areno sa (SANTOS, op. cit.). Podem ser estratificados ou maciços. São amarelos, ou localmente acinzentados.

os clastos, de diferentes tamanho, forma e compos $\underline{i}$ ção, estão dispersos, de maneira caōtica, dentro da matriz. Suas dimensões variam de milimëtricas a centimëtricas. Sei xos com estrias, principalmente, do tipo subparalelo 
(WENTWORTH, 1936) são encontrados.

As estruturas presentes nos diamictitos restringem- se à estratificação em camadas centimétricas e a intercala ções de corpos tabulares subverticais, e lenticulares, e frag mentos de camadas rompidas de arenitos finos a médios, maci ços ou estratificados, medianamente selecionados, imaturos, podendo conter microclastos de argilito e de outras litolo gias. As intercalações arenosas, em muitos casos, exibem si nais de deformações, provavelmente ocorridas quando ainda no estado hidroplāstico. Os seus contatos com a matriz dos dia mictitos podem ser bruscos ou erosivos.

Quanto aos ritmitos, apesar de estarem pouco repre sentados, quantitativamente, ao longo de seção, podem atin gir espessuras de até 25 metros, tornando-se significativos, localmente. Basicamente, são alternāncias de lāminas de sị tito ou arenito fino, claro, com folhelhos escuros. Seixos isolados e pistas, provavelmente de artrōpodes, são as prin cipais estruturas encontradas.

Finalmente, argilito e folhelho constituem as lito logias subsidiārias da parte exposta da seção. 0 argilito é maciço, de coloração esverdeada, enquanto que o folhelho, cinza escuro, pode encerrar pequenas lentes arenosas.

SALTO-RIO DAS PEDRAS. A seção em foco foi medida ao longo da antiga estrada que liga as cidades de Salto e P racicaba, entre a primeira localidade e a de Rio das Pedras. 0 seu ponto inicial situa-se junto à saída de Salto para Ca pivari, alguns metros após o ribeirão Ajudante, enquanto que o seu término situa-se a $7 \mathrm{~km}$ alēm da cidade de Mombuca, em direção a Rio das Pedras (Figura 1).

De maneira similar à seção anterior, tanto o conta to inferior da sequéncia examinada, com o embasamento crista lino (Prē-Cambriano), como o superior, localmente, com intru 
sivas bāsicas (Eocretāceo), não são diretamente observāveis ao longo dessa estrada.

0 Grupo Tubarão na ārea é constituĩdo,principalmen te, de arenitos, siltitos, ritmitos, diamictitos e folhelhos, perfazendo, uma espessura calculada em $954 \mathrm{~m}$. Destes, $904 \mathrm{~m}$ correspondem ao Subgrupo Itararē e os $50 \mathrm{~m}$ restantes à se quência pōs-glacial (Formação Tatuī) (Figura 6).

Subgrupo Itararē. Dentre as litologias que fazem parte do Subgrupo Itararé na ārea estudada, os arenitos são os que predominam nesta seção (aproximadamente, 50\% da espes sura total). Estes ocorrem tanto isoladamente, quanto inter calados nos diamictitos. A sua granulometria é muito variá vel, aparecendo desde arenitos finos atē conglomeráticos. As cores mais frequentes são as amareladas, avermelhadas e es branquiçadas. Outros minerais, alēm do quartzo, tais como feldspato e mica, presentes na composição mineralōgica de grande parte dos corpos examinados, qualificam-nos de imatu ros. Arenitos de seleção moderada a pobre predominam ao lon go da seção. Quanto à matriz, esta pode ser arenosa, argi losa ou sîltica sendo a primeira mais frequente. os conta tos, superior, inferior e lateral, com as litologias associa das podem ser bruscos, erosivos ou transicionais.

As espessuras medidas dos corpos arenosos variam de alguns atē o māximo de 40 a $50 \mathrm{~m}$. Vārias estruturas es tão presentes nos arenitos: estratificações gradacional, pla no-paralela e cruzada (tabular e/ou acanalada), de pequeno e grande porte, alēm de inclusões lenticulares de argilito e/ou arenito.

Com relação à geometria dos corpos, arenitos com forma de bancos foram identificados na base da seção, enquan to outros, lenticulares, estão presentes na parte média.

Quanto aos siltitos, estes podem ser maciços ou es 
tratificados. A estratificação, milimētrica, decorre do en riquecimento de argila ou de areia em determinados niveis. Sua matriz pode ser argilosa ou arenosa. Quando associados a diamictitos, de maneira similar a descrita anteriormente (p. 24), incluem pequenos seixos isolados em sua matriz.

0 siltito aflorante no ponto 87 , situado, aproxima damente, a $7 \mathrm{~km}$ da cidade de Capivari, em direção a Salto, contëm uma faūnula composta de Peruvispira delicata, Attenua telia sp., Limipecten capivariensis, Rhynchopora grosso punctata, Streblopteria sp., Phestia sp., alëm de colunais de crinōides (MENDES, 1952; ROCHA-CAMPOS, 1966). Corresponde à intercalação marinha de Capivari.

Os contatos dos siltitos com as litologias sobre postas e subjacentes são, frequentemente, bruscos ou grada cionais.

Os diamictitos, por sua vez, distribuem-se ao $10 \underline{n}$ go da seção em pelo menos, nove nỉveis diferentes, os quais localizam-se em maior nümero na parte mëdia a superior. Em bora, em sua maioria, formem corpos de pequena espessura $(2-3 \mathrm{~m})$, alguns de atē $12 \mathrm{~m}$ são encontrados.

Sua coloração é, geralmente, amarela, localmente, cinza. A matriz, de composição, predominantemente,silto-are nosa ou silto-argilosa (SANTOS, op. cit.), pode ser maciça ou estratificada. Os clastos, dispersos, caoticamente, na matriz, variam em composição, tamanho e forma. Suas dimen sões vão desde milimētricas atē centimētricas. Seixos es triados não são abundantes, sendo encontrados, somente, nos diamictitos da parte média da sequéncia. Nestes, o tipo de estria verificado foi o subparalelo (WENTWORTH, op. cit.).

Estratificação milimētrica, inclusões de camadas deformadas hidroplasticamente e corpos grosseiramente arre dondados de arenito fino a mëdio, em contatos bruscos e ero sivos com as litologias encaixantes, são as principais estru. 
turas verificadas.

os limites superior, inferior e lateral, dos dia mictitos com litologias associadas, podem ser bruscos, eros $\underline{i}$ vos ou gradacionais.

Jā os ritmitos localizam-se, principalmente, na parte inferior e média do Subgrupo. Espessuras considerá veis (de 40 a $50 \mathrm{~m}$ ) foram encontradas, gradando, localmente, para arenito ou siltito. Caracterizam-se pela alternância de lâminas de arenito fino ou siltito, com argilito ou folhe 1ho. Sua coloração è amarela-avermelhada ou cinza-esverdeada. Contēm, frequentemente, seixos isolados e ichnofösseis e, mais raramente, intercalações de lentes ou delgadas cama das de diamictito.

Quanto aos folhelhos, estes são micāceos e restrin gem-se a intercalações delgadas em arenitos finos, da baseda sequência sedimentar (pontos 1 a 3 ), nos quais foram encon trados restos carbonizados de plantas, muito mal conservados. Esta localidade corresponde, ao que tudo indica, à mesma des crita por BARBOSA \& ALMEIDA (1949a), que identificaram aí, a presença de Phylzotheca, Gangamopteris, Noeggerathiopsis, Glossopteris e Samaropsis.

Formação Tatuĩ. A Formação Tatuí, na ārea, ē com posta, principalmente, de siltitos, que embora alterados, exi bem, ainda, evidéncias da estratificação original. São, fre quentemente, violäceos e avermelhados, localmente esverdea dos. Raros e delgados corpos de arenito fino foram encontra dos intercalados a essa sequência sîltica.

0 contato entre as duas unidades litoestratigrāf $\underline{i}$ cas do Grupo Tubarão não foi observado ao longo desta seção, tendo em vista a ausēncia de afloramentos. 0 contato foi fixado, arbitrariamente, a aproximadamente $3,8 \mathrm{~km}$ alēm de Mombuca, em direção à cidade de Rio das Pedras. 
MARECHAL RONDON (SP-300). 0 exame da seção 1evan tada ao longo da Rodovia Marechal Rondon, entre os km 107 e 177,4 (Figura 1) mostrou ser esta uma das mais importantes dentre as examinadas, tendo em vista a abundância local de diamictitos, as relações claras entre os corpos litológicos e sua considerável espessura aflorante.

os contatos, inferior e superior, da sequéncia exa minada, embora não diretamente observāveis ao longo da se ção, fazem-se com rochas do embasamento cristalino (Pré-Cam briano) e Membro Taquaral da Formação Irati (Permiano), res pectivamente.

A espessura medida do Grupo Tubarão, através da me todologia utilizada, foi de $1193 \mathrm{~m}$, sendo $1073 \mathrm{~m}$ correspon dentes ao Subgrupo Itararē e $120 \mathrm{~m}$ à Formação Tatuí.

Subgrupo Itararé. As principais litologias que com põem o Subgrupo são: diamictitos, arenitos, siltitos e ritmi tos, enquanto que folhelhos e argilito ocorrem em percenta gem reduzida (Figura 6 ).

Os diamictitos, em sua maioria, apresentam matriz silto-argilosa ou silto-arenosa (SANTOS, op. cit.). Espessu ras de 2 até $35 \mathrm{~m}$ são encontradas, formando corpos maciços, de diferentes formas. Cores amareladas e/ou cinza-esverdea das são as mais comuns.

Clastos de composição e tamanho variados, geralmen te alongados, podem estar dispersos dentro da matriz ou for mar concentrações. As estrias encontradas, sobre a superfí cie dos clastos, foram as do tipo paralela e subparalela (WENTWORTH, op. cit.), além de marcas em crescente (ROCHA-CAMPOS, FARJALLAT \& YOSHIDA, 1969a).

Os diamictitos exibem estruturas, tais como:estra tificação milimétrica, alinhamentos horizontais de clastos, correspondentes a pavimento de clastos intra e, possivelmen 
te, intertiliticos (ROCHA-CAMPOS, FARJALLAT \& YOSHIDA, 1968; ROCHA-CAMPOS, SANTOS \& SAAD, 1972), inclusões sob a forma de camadas de arenitos argilosos, finos a médios, maciços, com deformações hidroplāsticas, ou de corpos esféricos, "vēnulas", "diques", lentes e canais de arenito grosso a conglomerātico (ROCHA-CAMPOS, FARJALLAT \& YOSHIDA, op. cit.; ROCHA-CAMPOS, SANTOS \& SAAD, op. cit.).

Nesta seção os diamictitos passam, gradacionalmen te, para siltito sobrejacente, ou mostram contatos bruscos ou erosivos com arenitos.

Os arenitos variam de finos a conglomerāticos. De um modo geral, são amarelados, feldspáticos, portanto, imatu ros, de seleção moderada a pobre e, por vezes, de matriz a $\underline{r}$ gilosa. Sua espessura varia de poucos (2-3), até dezenas (30-40) de metros. Arenitos em forma de bancos, lentes e ca nais localizam-se, principalmente, na parte média da seção.

As estruturas presentes nessa litologia são: estra tificações cruzada (tabular e acanalada), de grande porte, gradacional e plano-paralela, marcas ondulares migrantes, ichnofósseis, laminações convolutas, marcas de sobrecarga e concentrações lenticulares de seixos.

$0 \mathrm{~s}$ contatos dos arenitos com as rochas sub e sobre jacentes podem ser bruscos, erosivos ou gradacionais.

Com relação aos siltitos, estes, em sua maioria, restringem-se a pacotes pouco espessos $(5-6 \mathrm{~m})$, amarelos, ma ciços ou laminados, argilosos, podendo conter inclusões len ticulares de arenito fino. Os do ponto 210-215 da seção, con tudo, apresentam uma espessura anômala (aproximadamente $80 \mathrm{~m}$ ), alternando-se na sua parte superior, em contato brusco irre gular, com camadas de arenitos médios a finos, de atē $1 \mathrm{~m}$ de espessura, deformadas hidroplasticamente.

Os contatos, inferior e superior, dos siltitos com outras litologias podem ser bruscos, erosivos ou gradacio 
nais.

0s ritmitos caracterizam-se por alternānica de sil titos ou arenitos finos com folhelhos ou argilitos. Situam-se, estratigraficamente, na parte basal e média da seção, formando corpos de até $45 \mathrm{~m}$ de espessura. 0 par, de espessu ra milimétrica a centimétrica, inicia-se com termos mais grossos que podem passar, gradacionalmente, ou, bruscamente, às litologias de granulação mais fina. Frequentemente, en contram-se camadas de arenitos médios a grossos intercalados nos ritmitos, formando corpos descontinuos, de espessura va riāvel, que podem conter fragmentos de ritmitos. São comuns clastos centimētricos isolados, estruturas de sobrecarga e marcas onduladas. Dobras complexas e microfalhas, interpre tadas como resultando de escorregamento (ROCHA-CAMPOS, 1963) são também encontradas, afetando essa litologia.

Finalmente, com relação aos folhelhos e argilito, estes de um modo geral são pouco variāveis em suas caracte risticas. Os folhelhos, normalmente, de cor cinza escura, a lēm de intercalados em ritmitos, podem formar corpos isola dos associados a arenitos e diamictitos. Oargilito, por sua vez, é maciço, de coloração amarela-esverdeada, em que não se nota a presença de estruturas sedimentares.

Formacão Tatuí. A espessura encontrada para a For mação Tatuí $(120 \mathrm{~m})$, na ārea estudada, corresponde à maior verificada para essa Formação, dentre os oito perfis exami nados.

SOARES (1972), ao estudar o limite glacial/pōs-gla cial no Estiado de São Paulo, referiu-se a existência de con centração de seixos na base da Formação Tatuĩ, em perfis exa minados ao longo das rodovias Marechal Rondon, Castelo Bran co, Raposo Tavares e Tiete-piracicaba, o que evidenciaria, o caräter discordante do contato entre esta Formação e o sub 
grupo Itararé. Essa situação, contudo, não foi observada ao longo da seção, uma vez que o limite entre a Formação Tatuí e o Subgrupo Itararé, coincide, localmente, ao meu ver, com uma faixa sem afloramentos. 0 contato inferido situa-se en tre os km 169-170, nos arredores da localidade de Jumirim.

A litologia da Formação Tatuí, na ārea investigada abrange uma seqtência de siltitos, que na base da seção apre sentam cores arroxeadas, estrutura maciça ou laminação inci piente, passando, frequentemente, por tansição, para termos mais arenosos. Em direção à parte superior da Formação, pre dominam os siltitos argilosos, maciços, de cor cinza-clara, levemente esverdeada, podendo apresentar delgadas intercala ções arenosas.

VIA CASTELO BRANCO $(S P-280)$. A espessura medida do Grupo Tubarão, ao longo da rodovia Castelo Branco, segundo a metodologia utilizada, foi de $960 \mathrm{~m}$; sendo $880 \mathrm{~m}$ correspon dentes ao subgrupo Itararē, e os $80 \mathrm{~m}$ restantes à Formação Ta tuî. Não obstante, cerca de $590 \mathrm{~m}$, ou seja, $60 \%$ da espessu ra aflorante do Grupo Tubarão na ārea, estarem encobertos, a seção exposta ao longo da rodovia Castelo Branco pode ser ainda considerada como bastante representativa dá sequência Tubarão no Estado de São Paulo, por exibir algumas relações estratigrāficas importantes.

0 contato inferior, no ponto inicial do perfil le vantado $(\mathrm{km} \mathrm{79,4)}$, é discordante com as rochas do embasamen to cristalino (Prē-Cambriano). A parte terminal da seção corresponde ao contato entre a Formação Tatuỉ e intrusivas bāsicas (Eocretāceo) verificado no km 135 (Figura 1).

As rochas que compõem o Grupo Tubarão na ārea são, principalmente, siltitos, arenitos e diamictitos e, comple mentarmente, ritmitos, argilitos, folhelho e lamito (Figura $6)$. 
A rodovia Castelo Branco apresenta uma situação pe culiar em relação às demais estradas, dada a grande distān cia que separa as suas duas pistas e, consequentemente, os afloramentos situados em ambos os lados da estrada. 0 per fil colunar final representa, pois, uma composição dos aflo ramentos existentes, tanto na pista de ida (sentido este pa ra oeste) como na de retorno.

Subgrupo Itararē. Os siltitos predominam dentre as litologias que compõem o Subgrupo Itararē, na ārea. Embora sejam encontrados ao longo de toda a seção, incidem, com maior frequéncia, na parte média e superior.

De um modo geral, os siltitos, com espessuras de atē $30 \mathrm{~m}$, são maciços, de coloração amarela-avermelhada, 10 calmente, acinzentados, de matriz argilosa, em que às vezes estão dispersos clastos de tamanho milimētrico a submilimé trico, como acontece na parte mēdia da sequéncia Itararē. In clusões de lentes e delgadas camadas de arenitos finos a mé dios, amarelados ou avermelhados, feldspāticos e maciços são, tambēm, verificadas. Os contatos com as litologias, super postas e subjacentes, são bruscos ou erosivos.

Quanto aos arenitos, estes podem formar corpos in dependentes ou intercalados nos siltitos, como jā vimos, nos diamictitos, nos argilitos e nos próprios arenitos. Podem ser maciços ou estratificados e as espessuras chegam a deze nas de metros, no caso dos corpos isolados. Sua forma è a de canais e bancos. Toda a série de termos arenosos ë encon trada, predominando os de granulação fina e mēdia. 0 grau de seleção varia de um extremo a outro, constatando-se maior incidência de arenitos de seleção moderada. 0 caráter felds pático da maioria dos corpos examinados evidencia a sua ima turidade.

As estruturas presentes são: estratificações plano- paralela, estratificações cruzada (tabular e acanalada), de 
pequeno e grande porte, e gradativa, níveis conglomeráticos, concreções calcíferas e marcas ondulares migrantes.

os contatos, superior e inferior, exibidos pelos arenitos com outras litologias podem ser bruscos, erosivos ou gradacionais.

Os diamictitos, por sua vez, formam corpos de for mas variadas, com espessuras em torno de alguns metros. 0 nümero de nīveis é apreciāvel e, pelo menos de 13 a 14 hori zontes foram reconhecidos.

Anālise sedimentolōgica de trinta e nove amostras mostrou que a matriz varia desde areno-argilosa até argilo- siltosa (SANTOS, op. cit.). Esta pode sermaciça ou estra tificada. A cor predominante é a amarela-avermelhada, 1oca mente, acinzentada.

os clastos, geralmente, de forma alongada, polidos e facetados, podem estar dispersos, caoticamente, e/ou alinhados horizontal ou sub-horizontalmente, dentro da matriz. Estrias do tipo paralela e subparalela (WENTWORTH, op.cit.) são as mais frequentes na superfíciedos clastos examinados.

Os diamictitos exibem vārias estruturas, tais como, estratificação milimētrica, inclusões de canais, corpos esfé ricos, camadas rompidas e contorcidas, e lentes de arenitos médios a grossos, maciços ou estratificados, feldspāticos, micāceos e de coloração amarela-avermelhada. Algumas estru turas particulares observadas na parte mēdia da seção (pon to 97) merecem destaque especial. Neste local, dois diamic titos superpostos, discordantemente, estão separados por uma concentração horizontal de clastos, correspondente a um pavi mento mal desenvolvido. Corpos cuneiformes de arenito, por vezes conglomerático, de comprimento variāvel, atē cerca de $2 \mathrm{~m}$, estendem-se para baixo, a partir de camada arenosa na base do diamictito superior, intercalando-se no inferior. Estas estruturas foram interpretadas como pseudomorfos de 
cunhas de gelo desenvolvidas em substrato perenemente conge 1 ado ("permafrost").(ROCHA-CAMPOS et al., no prelo.)

0s contatos entre diamictitos e outras rochas são erosivos ou bruscos.

Com relação aos ritmitos, dois tipos diferentes de alternāncia litolōgica são entontrados: um formado de lâmi nas de arenito fino ou siltito, amarelo-avermelhado, com fo Thelho ou argilito, cinza-esverdeado, e o outro de camadas centimétricas de arenito fino com siltito, ambos amarelo- avermelhados. São comuns nessa litologia seixos isolados e ichnofósseis, ocorrendo, ainda, embora localmente, inter calações delgadas de diamictito.

Finalmente, argilitos, folhelho e lamito completam a seção litológica. Os argilitos são maciços ou estratifí cados, amarelo-avermelhados, localmente, acinzentados, poden do apresentar seixos milimétricos isolados e inclusões de ca madas de arenito fino, maciço, esbranquiçado, bem seleciona do ou lentes de siltito argiloso, maciço, amarelo-avermelhado. 0 folhelho é sîltico-argiloso, acinzentado e passa, gra dacionalmente, para ritmito subjacente. Quanto ao lamito,es te é, megascopicamente, maciço, de coloração cinza-esverdeada, exibindo intercalações lenticulares, delgadas, de arenito fino, maciço, micáceo, feldspātico, medianamente selecionado, em contato brusco com a litologia encaixante.

Formação Tatuĩ. De maneira similar a do perfil exa minado ao longo da rodovia Marechal Rondon, não foi constata da aqui, qualquer evidência indicativa de discordāncia entre - Subgrupo Itararē e a Formação Tatuí, sob a forma de nīveis conglomerāticos na base dessa ūitima unidade (SOARES op.cit.). 0 contato entre a Formação Tatuí e o Subgrupo Itararē não é diretamente observävel, tendo sido fixado, arbitrariamente, nas proximidades do $\mathrm{km} 131$. 
Essa Formação, na ārea examinada, abrange uma se quência monōtoma de siltitos. Junto à base, são de colora ção marrom-arroxeada, raramente laminados, enquanto que, em direção ao topo predominam as cores cinza-esverdeadas a ver des. Em alguns locais, ocorrem camadas de arenito médio,si toso, feldspātico e maciço, em contato brusco com os silti tos encaixantes.

SOROCABA-CERQUILHO (FEPASA). A seção medida ao lon go da estrada de ferro, entre as cidades de Sorocaba e Cer quilho, teve o seu ponto inicial fixado junto ao poste de sustentação da rede elētrica nūmero $99 / 8$, e seu final, junto ao de nūmero $165 / 5$ (Figura 1):

0 contato inferior do Grupo Tubarão faz-se, discor dantemente, com rochas quartzíticas do embasamento cristali no (Prē-Cambriano), enquanto que, o superior, com rochas do Grupo Passa Dois (Permiano), não é observāvel ao longo da ferrovia.

A espessura medida do Grupo Tubarão, na ārea levan tada, foi de $977 \mathrm{~m}$, abrangendo o Subgrupo Itararē (947 m) è a Formação Tatuí $(30 \mathrm{~m})$. As principais litologias que o ca racterizam são: arenitos, diamictitos e siltitos e, subsidia riamente, ritmitos e argilito (Figura 6).

Subgrupo Itarare. 0 s arenitos, representando, pelo menos, $55 \%$ da espessura medida do subgrupo, ocorrem interca lados nos diamictitos, nos siltitos, ou formam corpos inde pendentes. Suas espessuras, geralmente de 1-10 m, podem a cançar até $25 \mathrm{~m}$. As cores predominantes são: amarela e cin za clara, localmente, avermelhadas.

Os arenitos são maciços ou estratificados, neste caso por alternância de siltitos e argilitos. A granulome tria é bastante variāvel, ocorrendo desde arenitos finos até grossos. Ainda que pouco possa ser dito a respeito das ca 
racterísticas petrológicas, a presença de grandes quantida des de feldspato evidencia o caráter imaturo da maioria des ses sedimentos.

A seleção dos arenitos mëdios a grossos varia de me diana a pobre, sendo os finos, normalmente, bem selecionados. Seixos isolados, embora raros, foram verificados em alguns afloramentos.

As estruturas presentes resumem-se $\bar{a}$ estratifica ções cruzada (tabular e/ou acanalada), degrande porte, e gra dativa.

Camadas e canais maciços, sobrepostos em contatos bruscos, são as formas características dos corpos arenosos. Por vezes, apresentam um aspecto laminado, que se torna mais evidente pela decomposição do sedimento. Outros mecanismos, além dos deposicionais, podem ser considerados como responsā veis pela definição da forma de alguns corpos sedimentares. Possivelmente, os avanços e recuos das geleiras contribuiram para a modificação da forma original desses corpos. Exemplo disto, pode ser encontrado no km 107 da estrada de ferro (ponto 24), onde um corpo de arenito feldspātico foi inter pretado como forma topográfica moldada pelo fluxo do gelo(RO CHA-CAMPOS, FARJALLAT \& YOSHIDA, 1968).

os contatos exibidos pelos arenitos com outras $1 \underline{i}$ tologias são bruscos ou erosivos.

Os diamictitos, que representam $20 \%$ da espessura total dos sedimentos, distribuem-se ao longo da seção em qua torze horizontes diferentes, verificando-se sua maior concen tração na parte mëdia.

Embora, na maioria dos afloramentos, apresentem co loração amaiclada, os diamictitos, quando frescos, são acin zentados. Normalmente, são corpos, megascopicamente, maci ços, localmente, estratificados. 
Anālise sedimentológica de quarenta e seis amo tras indicou o predomínio da fração silte na maioria dos dia mictitos, assim como uma significativa contribuição percen tual desta fração nas amostras em que areia ou argila predo minam (SANTOS, op. cit.).

0s clastos apresentam-se dispersos, de maneira cao tica, na matriz e variam, em tamanho, de milímetros atē $50 \mathrm{~cm}$. Comumente, possuem forma alongada, sendo raros os equidimen sionais. São facetados, por vezes estriados, sendo as es trias de disposição paralela ou subparalela (WENTWORTH, op. cit.).

Numerosos corpos descontínuos, sob a forma de ca nais, camadas ou lentes de arenitos, argilitos e siltitos, de centimētricos a alguns metros de espessura, estão intercala dos nos diamictitos. Lentes e canais de conglomerados foram registrados, atingindo atē $5 \mathrm{~m}$ de espessura, como ocorre no ponto 200 da seção. Estes são compostos de fragmentos de ro chas e seixos de vārios tamanhos, atingindo até $50 \mathrm{~cm}$, de na tureza semelhante a dos diamictitos. Os corpos clásticos são, no geral, aparentemente maciços, podendo, os de granula ção mais fina, exibir estratificação plano-paralela. Os con tatos com os diamictitos são de difỉcil caracterização, dada a grande mistura de litologias. Evidências de deformações hi droplästicas, tais como camadas rompidas e/ou dobradas, e e truturas de sobrecarga foram assinaladas em vārios nīveis da seção.

Os contatos dos diamictitos com as litologias so brepostas e subjacentes podem ser erosivos ou bruscos.

Vale a pena notar a presença de quantidades variā veis de fragmentos macroscōpicos carbonizados de vegetais, dis persos na matriz dos diamictitos, principalmente na parte in ferior da seçào.

Quanto aos siltitos, estes exibem cores claras,pre 
dominantemente amareladas. Apresentam-se maciços ou, inci pientemente, estratificados, formando corpos de atē $14 \mathrm{~m}$ de espessura, em contato, normalmente, brusco com outras lito logias. Inclusões ou enriquecimentos locais de arenito fí no e lâminas de diamictitos ocorrem dentro de pacotes mací ços de siltitos. Microclastos, embora raros, podem ser ob servados dispersos na matriz.

os ritmitos, localizados, preferencialmente, na parte inferior da seção estudada, são formados de alternān cia de lâminas de siltito com argilito ou folhelho. Seixos isolados ou concentrados em intercalações finas são encontra dos deformando os estratos subjacentes. Alguns ritmitos incluỉdos em corpos arenosos exibem deformações hidroplāsti cas.

0 argilito situa-se na parte inferior da seção. E maciço, de coloração marrom-avermelhada, podendo mostrar es tratificação, ou uma certa fissilidade, quando intemperizá do.Localmente, pode conter raros microclastos.

Um breve comentārio merece ainda ser feito, no que tange às relações entre os sedimentos gondvānicos e as rochas alcalinas, que ocorrem na ārea em estudo, correspon dentes à intrusão de Ipanema (DAVINO, 1975).

Ao longo do leito da ferrovia, cujo traçado flan queia o corpo ígneo, os sedimentos do Grupo Tubarão exibem poucas evidéncias de terem sido afetados tectonicamente, pe los processos de intrusão daquelas rochas. No ponto 44 re gistrou-se a presença de um dique vertical, de $50 \mathrm{~cm}$ de es pessura que, embora bastante alterado, permite verificar não se tratar de rocha bäsica. 0 material decomposto é untuoso ao tato e constituído por fragmentos placóides amarelados. Nas proximidades de Varnhagem, afloram diversos canais de arenitos finos, branco amarelados, muito tenazes, provavel mente silicificados durante a intrusão magmätica alcalina na 
quela ārea (LEINZ, 1940).

Formação Tatuĩ. A espessura medida da Formação Ta tuî, ao longo da seção estudada, foi de $30 \mathrm{~m}$. Na parte infe rior, é formada de siltitos vermelhos, localmente esverdea dos, com aspecto estratificado realçado pelo intemperismo. Delgadas camadas de arenito fino e calcārios estão intercala das em diferentes nîveis da sequência sỉltica. Em direção ao topo, predomina uma sucessão monótona de siltitos averme 1hados. A sequencia acima descrita corresponde, ao que pare ce, à base da Formação Tatuí na ārea. De maneira similar às seções anteriores, o contato entre as rochas do subgrupo It rarē e Formação Tatuí não é observāvel ao longo da seção. Es te foi estabelecido, arbitrariamente, junto do poste 164/7, da ferrovia.

VIA RAPOSO TAVARES $(S P-270)$. 0 perfil levantado ao longo da rodovia Raposo Tavares abrangeu desde $0 \mathrm{~km} 102$ (So rocaba), até o km 162,5 (Itapetininga). (Figura 1.)

Tanto os contatos inferior do Grupo Tubarão, com ro chas do embasamento cristalino (Pré-Cambriano), como o supe rior, com o Grupo Passa Dois (Permiano), não foram diretamen te observados, ao longo dessa estrada. A espessura medida da sequéncia Tubarão, segundo a metodologia utilizada, foi, pois, de $821 \mathrm{~m}$, dos quais $780 \mathrm{~m}$ correspondem ao Subgrupo It raré e os $41 \mathrm{~m}$ restantes, à Formação Tatuí.

$\mathrm{Na}$ ārea estudada, o Grupo Tubarão caracteriza-se pe la predominância de diamictitos, arenitos e siltitos, e quan tidades subsidiārias de ritmitos, lamito e argilito (Figu ra 6 ).

Subgrupo Itararē. Os vārios nīveis de diamictitos, que representam pelo menos $30 \%$ da espessura total das 1 itolo gias aflorantes, localizam-se, preferencialmente, na parte mēdia da seção estudada. 
Nos locais onde os diamictitos sustentam magnifi cos cortes, ao longo da rodovia, pode ser constatada uma gra dação de cores cinzas, nas partes mais frescas, para amare ladas em zonas mais alteradas.

Os resultados das anāitises sedimentológicas em trin ta e seis amostras, mostraram que a matriz dos diamictitos são, geralmente, silto-arenosas e/ou silto-argilosas (SANTOS, op. cit.).

Megascopicamente, os diamictitos apresentam-se não estratificados, embora, quando observados à distāncia, em al guns afloramentos exibam uma espécie de foliação ou fissili dade que pode ser confundida, ou mesmo corresponder, à estra tificação incipiente.

Os clastos, geralmente de forma alongada, polidos e facetados, têm dimensões variando de milīmetros até $80 \mathrm{~cm}$. Comumente, estão dispersos, caoticamente, na matriz, poden do, em alguns afloramentos, formar concentrações locais, que lembram alinhamentos horizontais. Apesar de não serem fre quentes, são encontrados clastos com estrias do tipo parale la e subparalela (WENTWORTH, op. cit.).

Camadas, lentes, canais, corpos esféricos e cunei formes de arenitos ocorrem, em contato brusco, intercalados nos diamictitos. São, geralmente, de granulação fina a mé dia, por vezes, grossa ou conglomerātica, maciços ou estrati ficados. Tais corpos podem dispor-se em posição horizontal e inclinada, sem evidēncias de deformações ou, então, defor mados hidroplasticamente. Os corpos cuneiformes são, geome tricamente, similares a outros descritos como pseudomorfos de camadas de gelo, ou mesmo, de crevasses (FRAKES, FIGUEIRE DO \& FULFARO, 1968; ROCHA-CAMPOS et al., no prelo).

Os contatos com outras litologias podem ser brus cos, erosivos ou gradacionais. 
Os arenitos que representam, pelo menos, $30 \%$ da espessura total dos sedimentos aflorantes, possuem colora ção amarelada ou rósea. A granulometria é muito variada,en contrando-se desde arenitos finos, bem selecionados, até arenitos conglomerāticos polimîticos, Com exceção dos de granulação fina, os demais são imaturos, como evidencia a presença de quantidades razoāveis de feldspato em suas com posições.

A forma dos corpos de arenito pode ser acanalada, lenticular ou tabular, com aspecto, normalmente, maciço, ou exibindo laminação plano-paralela. Outras estruturas pre sentes são estratificações cruzada (acanalada e tabular), de grande porte, e gradativa.

os arenitos exibem contatos erosivos, bruscos ou gradacionais, com outras litologias.

Quanto aos siltitos, estes são, usualmente, maci ços, embora uma estratificação incipiente possa ser observa da em afloramentos intemperizados. Por vezes, contém in cluídos corpos centimëtricos de arenito fino, em forma de canais ou camadas. Contatos bruscos ou gradacionais foram os verificados com as litologias sobrepostas e subjacentes.

os sedimentos classificados como ritmitos são com postos de alternāncia de láminas de siltito, amarelo-averme 1hado, e argilito, amarelo, localmente cinza, ou, pela al ternāncia de camadas de arenito fino e siltito, amarelo- avermelhados. Estruturas de deformação são frequentes na base das unidades de granulação mais grossa, ao que parece causadas por compactação diferencial.

o lamito, na ūnica ocorrēncia identificada ao 1on go da rodovia, é acinzentado a amarelado, aparentemente ma ciço. Em zonas mais intemperizadas, exibe uma espécie de fissilidade, possivelmente correspondendo a estratificação pouco desenvolvida. Esta pode ser ainda destacada pela pre 
sença de faixas horizontais cimentadas por carbonatos.

Este pacote inclui, junto à base, concreções centi métricas de composição calco-fosfātica, de forma ovalada, contendo uma fauna marinha composta de foraminifferos arenā ceos, dentes, espinhos e escamas de peixes. 0 nūcleo de mui tas das concreções é ocupado por coprōlitos, de peixes, do tipo "enterospira", muito semelhantes às formas descritas,tam bem de concreções, de idade carbonífera, nos Estados Unidos da América do Norte, Europa e Africa. 0 lamito encerra uma associação de foraminíferos arenāceos, dentre os quais foram identificados espēcies de Hyperammina, Ammodiscus, Brunsiezza, Textularia e Reophax (LIMA et al., no prelo).

Formação Tatuí. A Formação Tatuĩ, na ārea, ē com posta de siltitos de coloração variegada, nos quais, apesar de intemperizados, ē possível identificar-se delgadas inter calações de arenito fino. O contato entre a Formação Tatuĩ e o Subgrupo Itararē, não è diretamente observāvel, ao longo da estrada, tendo sido, pois, fixado na altura do km 155,8. De maneira similar ao que ocorre nas rodovias Castelo Branco e Marechal Rondon, a base da Formação Tatuí não exibe evidēn cias texturais da discordāncia erosiva identificada por SOARES (op. cit.), em outras partes do Estado de São Paulo.

Como já citado, anteriormente, o contato entre os Grupos Tubarão e Passa Dois, não é tambēm observāvel ao 1 on go do trecho examinado. Assim, os $41 \mathrm{~m}$ de sedimentos medi dos, correspondentes à Formação Tatuī, representam, somente, a parte inferior do pacote de siltitos.

CAPÃO BONITO-ITAPETININGA (SP-127). A seção em fó co foi medida entre o km 117 da estrada que 1iga Capão Bon to a Fazendinha, até, aproximadamente, o km 186 da rodovia SP-127, junto ao entroncamento com a rodovia SP-270. (Figura 1.). 
0 Grupo Tubarão, na ārea estudada, perfaz, de acor do com a metodologia utilizada, um total de $930 \mathrm{~m}$ de espes sura, abrangendo o Subgrupo Itararé $(861 \mathrm{~m})$ e a Formação Ta tuí (cerca de $69 \mathrm{~m}$ ). O contato inferior da sequência è dis cordante sobre quartzitos do embasamento cristalino (Prē- Cambriano), enquanto que o superior, com as rochas do Grupo Passa Dois, não é observāvel.

Apesar da pobreza de afloramentos, particularmente, no terço inferior da seção, os dois terços restantes exibem, suficientemente, as características do subgrupo Itararé, na ārea constituído de diamictito, arenitos, siltitos, ritmitos, folhelho e argilito (Figura 6).

Subgrupo Itararé. Diamictitos perfazem, pelo menos, $42 \%$ da espessura total dos sedimentos aflorantes, estando con centrados, principalmente, nas partes média e superior da se ção.

De um modo geral, os diamictitos são de coloração cinza, maciços, localmente estratificados com intercalações decimétricas de canais, "bolas", lentes e camadas de aren tos de seleção variada, de granulação fina a grossa, aparen temente, maciços, ocasionalmente, estratificados plano-para lelamente.

Intercalações centimétricas de ritmitos constituí dos de argilito preto e siltito amarelo, com alguns clastos isolados, foram tambēm, registradas em vārios afloramentos. No ponto 72 , onde alcançam espessuras de 2 a $20 \mathrm{~cm}$, repetem-se em värios nïveis dentro de um mesmo diamictito, sendo que alguns podem apresentar-se dobrados.

As estruturas mais importantes associadas aos dia mictitos, foram assinaladas no ponto 76 , onde corpos areno sos e conglomerāticos ovalados ou em cunha, respectivamente, foram interpretados como posíiveis "eskers" fósseis e preen chimentos de crevasses abertas em antigo "til1" congelado 
(FRAKES, FIGUEIRED0 \& FULFARO, 1968).

os clastos de diferentes forma, tamanho e compos $\underline{i}$ ção podem estar dispersos, de maneira caótica, na matriz ou, então formar concentrações horizontais de até $3 \mathrm{~cm}$ de espes sura. No geral, os diamictitos contēm maior quantidade de clastos milimétricos do que centimétricos, com exceção do afloramento do $\mathrm{km} \mathrm{167-168} \mathrm{(ponto} \mathrm{73)} \mathrm{reconhecido} \mathrm{como} \mathrm{tili}$ to verdadeiro por LANDIM (1970). Neste, muitos clastos apre sentam estrias do tipo paralelo, subparalelo e em grade (WENTWORTH, op. cit.).

os resultados das anälises sedimentolögicas efetua das em amostras coletadas ao longo do perfil, permitem carac terizar a matriz dos diamictitos como, predominantemente,si 1 to-argilosa, com pouca contribuição da fração areia (SANTOS, op. cit.).

Os contatos do diamictito com outras litologias po dem ser bruscos, erosivos ou gradacionais.

Os arenitos, de coloração amarela-avermelhada, es tão presentes desde a base, até o topo da seção. 0s corpos arenosos, normalmente, sob a forma de canais e/ou camadas, são constituỉdos, predominantemente, de arenitos de granulação fina ou muito fina, com matriz argilosa, por vezes feldspā tica e seleção variando de regular a boa. Arenitos médios e grossos localizam-se, principalmente, na base da seção onde são, geralmente, maciços, mal selecionados e com gran des porcentagens de feldspato.

Estruturas singenēticas são raras e foram registra das, somente, no afloramento do ponto 26. Neste 1ocal, a se quência inicia-se com arenito grosso, feldspätico, ' maciço, mal selecionado, sotoposto, em discordância, a um arenito fi no, maciço e bem selecionado, onde puderam ser reconhecidos alguns clastos centimētricos dispersos na matriz, a lēm de mar cas de onda e intercalações de lāminas de diamictito rico em 
clastos. Nas partes superiores do afloramento, onde o aren $\underline{i}$ to torna-se estratificado com camadas de argilito cinza-es verdeado, foram observados algumas sequéncias de microestra tificações cruzadas, estratificações cruzadas por migraçãode marcas de onda, leitos de argila corrugados, pseudo-nódulos e pequenas estruturas de sobrecarga.

os contatos com as litologias sobrepostas e subja centes são bruscos, gradacionais ou erosivos.

os siltitos localizam-se nas partes inferior-mēdia e superior da seção. São de coloração amarela-avermelhada ou cinza-esverdeada, maciços, localmente estratificados. Apre sentam intercalações, na forma de lâminas ou delgadas cama das, de arenito fino, maciço, medianamente selecionado, po dendo ocorrer, ainda, microclastos isolados. Os contatos com as litologias associadas podem ser bruscos ou gradacionais.

Os ritmitos, por sua vez, localizam-se, preferen cialmente, na parte média da seção e são compostos de alter nāncia de lâminas de siltito amarelado, e argilito de colora ção preta ou cinza-esverdeada, em contato brusco. E comum a ocorrēncia de ichnofōsseis, semelhantes às jā relatadas, representantando, provavelmente, pistas de artrōpodes. Inter calações arenosas podem estar presentes nos ritmitos. As identificadas no afloramento correspondente ao ponto 87 , são constituĩdas de camadas decimétricas de arenito fino, bem se lecionado, branco-amarelado, contendo vārias sequências de microestratificação cruzada. Nesta seção, os ritmitos pos suem contatos brusco e erosivo com diamictitos, transicional com folhelho e siltito e erosivo com arenito.

Folhelho e argilito foram identificados apenas em afloramentos localizados nas partes média e inferior da se ção. 0 folhelho possui coloração cinza-esverdeada, enquanto que, o argilito, amarelo-avermelhado, é, aparentemente, maci 
ço.

Formação Tatuí. Os afloramentos atribuídos à For mação Tatuĩ, na rodovia SP-127, aparecem no km 184. 0 conta to com as rochas do Subgrupo Itararé não pode ser observado, pois, localmente, uma faixa sem afloramentos separa as duas unidades .

A Formação Tatuĩ, na ārea, ē composta de siltitos estratificados, de coloração verde-avermelhada, com delgadas intercalações arenosas. Apresentam-se bastante intemperiza das, dificultando, sobremaneira, uma anāilise mais minuciosa.

0s siltitos acima descritos correspondem, provavel mente, à base da Formação Tatuí na ārea. O seu contato, com as rochas do Grupo Passa Dois, não foi observado.

ITARARE-TAQUARITUBA $(S P-281)$ E $(S P-249)$. Esta se ção representa uma composição do perfil medido em duas estrá das: a primeira, iniciando-se a trēs quilómetros ao sul da cí dade de Itararé, prōximo à usina Três Barras, e com tērmino no entroncamento com a estrada Taquarituba-Itaberaba (SP-249), e a segunda, entre os km 147-160 dessa mesma rodovia (Figu ra 1). Assim, a espessura calculada do Grupo Tubarão nessas estradas, em conjunto, foi de $1118 \mathrm{~m}$. Desse tota $1,1107 \mathrm{~m}$ pertencem à sequéncia glacial, enquanto que, os $11 \mathrm{~m}$ restan tes são atribuĩdos à Formação Tatuí.

As principais litologias que fazem parte da sequến cia Tubarão na ärea estudada são: diamictitos, siltitos, are nitos e, subsidiariamente, ritmitos e argilito: (Figura 6).

0 contato inferior do Grupo è discordante sobre a Formação Furnas, unidade basal do Grupo Paranä (Devoniano), enquanto que o superior faz-se, localmente, com rochas bäs $\underline{i}$ cas (Eocretáceo) do "sill" de Taquarituba. 
Subgrupo Itararē. Os diamictitos, que representam, pelo menos, $34 \%$ da espessura total dos sedimentos, estão con centrados na parte inferior da seção, onde alcançam espessu ras individuais de atē $75 \mathrm{~m}$.

Exibem coloração amarelada e são, normalmente, ma ciços. Apenas no ponto 39 foi verificada a presença de pro vāvel estratificação nas partes mais superiores e alteradas do afloramento.

Os resultados de dezenove anālises sedimentolōgicas indicam que a matriz dos diamictitos tem composição, princi palmente, sîltica com apreciāveis proporções de areia e quan tidades subsidiārias de argila (SANTOS, op. cit.).

Clastos de vārias composições ocorrem dispersos, de maneira caōtica, na matriz. São de dimensões variāveis, usual mente milimētricos a centimētricos, raramente alcançando $30 \mathrm{~cm}$. Normalmente são facetados e de forma alongada. Embora não seja frequente, podem exibir estrias dos tipos paralelo e subparalelo (WENTWORTH, op. cit.).

Estratificações milimētricas, lentes, camadas e corpos esféricos, aparentemente, não deformados, de arenitos mal selecionados, de granulação fina, mëdia e conglomerātica, com contatos, normalmente, bruscos ou erosivos, são as princi pais estruturas encontradas nos diamictitos. Por falta de bons afloramentos, as relações de contato dos diamictitos com outras litologias não, puderam ser perfeitamente caracte rizadas. Contudo, algumas passagens bruscas para siltitos e ritmitos, ou graduais, para arenitos médios, foram observa das nos pontos 79,60 e 78 , respectivamente.

Quanto aos siltitos, estes podem ser maciços ou es tratificados, de coloração amarelada, localmente cinza-esverdea da, argilosos e micāceos. Por vezes, possuem intercalações centimētricas a decimētricas de arenitos finos, ärgilitos ou 
diamictitos, sob a forma de canais ou camadas.

A sequência sîltica aflorante entre os pontos 141 e 158 contēm, na sua parte inferior, fósseis marinhos, in cluindo o bivalve Nuculana limai Mezzalira e braquiōpode Orbiculoidea cf. guaraunensis 01 iveira (MEZZALIRA, 1956). Verifica-se, aqui, novamente, a correspondência entre a $1 \underline{i}$ tofácies sīltica e a ocorrēncia de fósseis marinhos, jā men cionada, anteriormente.

os arenitos, por sua vez, perfazem, aproximadamen te, $29 \%$ da espessura total da seção. Como pode ser observa do no perfil colunar (Figura 6), considerando-se, somente, a distribuição dos termos arenosos, estes podem ser subdividi dos em três partes, cada uma delas com características in teiramente prōprias e diferentes das demais. Assim sendo, o terço inferior é caracterizado pela presença de canais e camadas de arenitos grossos, esbranquiçados, mal seleciona dos, de matriz siltosa e estratificados plano-paralelamente. do GeAlguns níveis possuem, tambēm, estratos cruzados do tipo

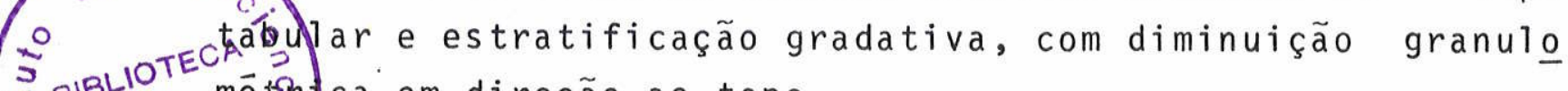
B BIBLIOTEC métrir ca em direção ao topo.

No terço médio predominam os arenitos médios e fí U. S. hos, maciços, esbranquiçados, feldspāticos, de matriz silto sa, com seleção de boa a mā. O terço superior è caracter zado por arenitos finos, de cor amarela, medianamente a bem selecionadas, argilosos, maciços ou estratificados, podendo exibir micro laminações cruzadas.

Os contatos, superior e inferior, com outras lito logias podem ser bruscos ou gradacionais.

os ritmitos estão presentes nas partes mēdia e su perior da seção. No afloramento correspondente ao ponto 83 , o sedimento rítmico ē formado por uma alternāncia de $1 a ̂ m \underline{i}$ nas de siltito argiloso, amarelo-esverdeado e diamictito, tambēm argiloso, de coloração amarela-esverdeada. Dentro do 
pacote aparecem delgadas camadas de arenito fino, sem evidēn cias de deformação. 0 da parte superior da seção é composta de alternāncia de lâminas de siltitos e argilitos, com sei xos isolados e pistas, provavelmente, de artrōpodes, em vá rios niveis do afloramento.

0 argilito, reconhecido, somente, no afloramento correspondente ao ponto 43 da seção, tem cor cinza-esverdeada, que põe em evidéncia o seu aspecto estratificado.

Formação Tatuĩ. As rochas pertencentes a essa For mação afloram, apenas, ao longo de $500 \mathrm{~m}$ ao longo da rodovia SP-249 (km 155,5-160), sendo que o seu contato com o subgru po Itararē não é visĩvel ao longo da seção levantada.

As litologias aí presentes são siltitos argilosos, com raras e finas intercalações arenosas. Sua coloração é vermelha-amarelada e embora estejam bastante intemperizados, uma aparente estratificação pode ser observada. 


\section{5 - ESTRATIGRAFIA}

GENERALIDADES. Os resultados do trabalho de campo realizado, conforme relato anterior estão consubstanciados no painel estratigrāfico da Figura 6 .

Este exibe a sequência estratigräfica ao longo dos oito perfis, acrescido de mais um compilado da literatura (SOARES \& LANDIM, 1973, p. 245, Figura 2), sob a forma de se ções colunares, organizadas grosseiramente, de SO-NE. Em ca da coluna, as relações espaciais mostradas entre os corpos de litologias reconhecidas correspondem àquelas, realmente, verificadas, diretamente, no campo ou resultam de reconstru ção, atravēs de correlação em base litolōgica ou, puramente, geomētrica. Em cada caso, procurou-se utilizar convenções adequadas para representar as diferentes situações. As rela ções espaciais entre os diversos pacotes rochosos, assim re constituidos, puderam ser controlados, paleontologicamente, em grande parte, atravēs de anālise do conteūdo palinolōgico, como serā relatado posteriormente. Os resultados foram acha dos consistentes, dentro do poder de solução do método bioes tratigräfico utilizado.

Um cuidado adicional tomado na representação grāfí ca de cada coluna refere-se à disposição das litofácies, re lativamente ao sentido do mergulho regional. Com o objetivo de tornar as colunas mais representativas, a sucessão de 1 i tofācies de leste para oeste estā representada, da direita para a esquerda em cada coluna. Estas, como jā comentei an teriormente, exibem um empilhamento, até certo ponto, artifi cial, tendo em vista a distāncia horizontal que separa os pa cotes de rochas, ao longo de cada perfil examinado.

Não obstante essas deficiēncias, o painel estrati grāfico constitui, provavelmente, uma representação bastante 
aproximada da distribuição horizontal e vertical das rochas do Grupo Tubarão, na margem leste da Bacia do Paranā, na re gião central e sul do Estado de São Paulo.

Como veremos em seguida, os dados paleogeogräficos existentes indicam que o perfil obtido ē, grosso modo, coin cidente com a direção deposicional, nesta parte da Bacia do Paranā e, neste caso, significativo para a anālise das varia ções de fácies e da histōria tecto-sedimentar do Grupo.

Quanto à correlação geral entre as colunas, ela só pode ser feita, grosseiramente, tendo em vista a extrema va riação na distribuição espacial dos corpos de rocha, como se depreende do seu exame inicial.

0 datum utilizado, para a correlação, o ūnico dis ponível no àmbito da pesquisa realizada, foi a base da Forma ção Tatuí. Esta solução apresenta vantagens de ordem prāti ca, tendo em vista a identificação, relativamente fācil, no campo, dos sedimentos pertencentes a essa unidade, sendo,tam bēm, aceitável do ponto de vista bioestratigrāfico, com base nas seguintes evidēncias:

1) 0 comportamento relativamente regular do hori zonte escolhido, em termos bioestratigrāficos, conforme se depreende do exame do painel de correlação dos poços estuda dos por DAEMON \& QUADROS (1970, Figura 4). 0 datum utiliza do por esses autores (base do intervalo bioestratigrafico $K$ ) corresponde, na ārea abrangida pelo presente estudo, ao limi te Itararē-Tatuí.

2) As evidências bioestratigräficas disponīveis, tanto a partir da literatura (DAEMON \& QUADROS, op. cit.), quanto derivada do trabalho aqui realizado (Figura 8) não indicam qualquer descontinuidade significativa na sucessão de microfloras na parte superior do Subgrupo Itarare (p.64). Assim sendo, a discordância erosiva postulada por SOARES 
(1972), que separaria as duas unidades do Grupo Tubarão, não parece abranger um hiato deposicional tão extenso quanto o interpretado por MEDEIROS \& THOMAZ FILHO (1973,Figura 2), pa ra ser detectado mesmo atravēs de anālise palinolōgica mais detalhada, como a aqui realizada.

Julgo, portanto, que, pelo menos, provisoriamente, pode-se aceitar a hipōtese de que o datum litoestratigrāfico utilizado coincide com limite bioestratigráfico adequado, na ārea em estudo.

Como se depreende da anāilise da Figura 6 , a comple xa disposição espacial dos corpos de litologias do Subgrupo Itararé torna precāria qualquer tentativa de correlação de detalhe, com base puramente litológica, a não ser a pequena distāncia. 0 entendimento da evolução tecto-sedimentar de pende, pois, de controle bioestratigráfico, que se mostrou mais satisfatōrio para correlação regional.

0 exame do painel, contudo, permitiu reconhecer a existência de conjuntos de litologias, que a despeito de va riações laterais - provavelmente ao longo da direção depos $\underline{i}$ cional - guardam relativa consistēncia e parecem ter signifi cado no discernimento da evolução sedimentar do Grupo, como discutirei a seguir.

Os dados bioestratigräficos disponiveis parecem in dicar tambëm que, pelo menos em um caso (entre os conjuntos $B-C)$, o limite entre os conjuntos litológicos reconhecidos é, razoavelmente, coincidente com o limite bioestratigräfico en tre as microfloras neles contidos, o que constitui evidência em apoio à utilidade prätica do seu reconhecimento (Figura 7):

SUBDIVISÃO LITOESTRATIGRAFICA. A subdivisão, aqui reconhecida, derivou da anālise da distribuição, tanto na vertical como na horizontal, das litologias clásticas finas (arenitos finos, siltitos, ritmitos, argilitos e folhelhos) 
em relação às clāsticas grossas (arenitos médios a conglome rados) e diamictitos. A categoria litoestratigrāfica das unidades, aqui denominadas conjuntos, não estā, ainda, per feitamente clara, podendo corresponder a formações (ou mem bros), o que só poderā ser eclarecido através de trabalhos cartogrāficos complementares.Embora consistentes, internamen te, são unidades complexas de limites pouco discerníveis.

Atravēs do exame do painel estratigrāfico (Figura 6), cinco conjuntos litológicos puderam ser reconhecidos no Grupo Tubarão. Seus limites, grosseiramente traçados, tive ram por base, os controles estratigrāficos disponīveis. A partir do inferior, caracterizam-se por:

Conjunto A: clāsticos finos associados a diamicti tos e clāsticos grossos, na região centro-leste. Em direção ao sul, predominam diamictitos e clásticos grossos em rela ção aos finos;

Conjunto B: maior incidēncia de clásticos finos, ocorrendo, subsidiariamente, diamictitos e clāsticos grossos. Tal caracteristica persiste ao longo de toda faixa deposicio nal:

Conjunto C: grande quantidade de clāsticos finos, associados a diamictitos e clāsticos grossos, na parte cen tro-leste, enquanto que em direção ao sui e a nordeste, vol tam a predominar clāsticos grossos e diamictitos, em relá ção aos termos mais finos;

Conjunto D: mesma situação verificada no conjunto B. Tanto na região centro-leste, como na centro-sul, hā maior incidência de clāsticos finos, em relação aos grossos e diamictitos. Na região nordeste predominam os clāsticos grossos sobre os demais termos litológicos;

Conjunto E: constituído de siltitos. variegados (principalmente, avermelhados e esverdeados) e arenitos finos. 
Do ponto de vista estratigrāfico, os quatro conjun tos inferiores correspondem ao Subgrupo Itararé, enquanto que o mais superior representa a Formação Tatuí.

E interessante notar, ainda,que os quatro conjun tos inferiores poderiam ser agrupados em dois $(A+B$ e $C+D)$, caracterizados, grosso modo, por variação vertical granulomé trica, de clásticos grossos $(A+C)$, para clásticos finos $(B+D)$. Se atentarmos para um exame mais geral, envolvendo os nove perfis ilustrados, notaremos que idêntico padrão è verifica do na horizontal. De SO-NE nota-se uma variação granulométrica geral, desde clästicos mais grossos para mais finos, notadamente nos conjuntos $A$ e $C$.

0 padrão de variação textural acima discutido pode ria estar relacionado à de fatores tectōnicos regionais, que atuaram durante deposição dos ciclos A e C, como será discu tido posteriormente.

0 exame do painel da Figura 6 permite identificar, ainda, as características gerais quanto à distribuição das litologias e estruturas associadas, na ārea de estudo:

a) verifica-se maior incidencia de nūmero de cor pos de diamictitos (associada a maiores espessuras) nas se ções mais espessas examinadas, particularmente, na via Mare chal Rondon.

b) Apesar de serem verificadas vārias estruturas sedimentares associadas aos corpos diamictiticos, as princi pais localizam-se no conjunto $D$, mais precisamente, nas se ções Castelo Branco, Marechal Rondon e na rodovia SP-127. Na primeira, são verificados no contato entre dois diamictitos (ponto 97), além de pavimentos de clastos, corpos cuneifor mes de arenito, que parecem corresponder a pseudomorfos de cunhas de gelo desenvolvidos em solo perenemente congelados (ROCHA-CAMPOS et al., no prelo). Na segunda, prōximo a cida 
de de Jumirim, ROCHA-CAMPOS, FARJALLAT \& YOSHIDA (1968) des creveram em diamictito, da parte superior do Subgrupo Itara rē, uma concentração horizontal de clastos, a qual parece corresponder a um tipo de pavimento de clastos. Na rodovia Capão Bonito-Itapetininga, as estruturas encontradas foram identificadas como possīveis "eskers" fósseis e preenchimen to de crevasses, cortando um diamictitto arenoso, tambēm, da parte superior do subgrupo Itararē (FRAKES, FIGUEIREDO \& FUL FARO, 1968).

c) Os ritmitos contendo pistas de artrōpodes não são caracterīsticos de determinado conjunto, ocorrendo em vá rios nỉveis, ao longo das seções examinadas. Com relação às estruturas de deformações hidroplāsticas, estas afetam os ritmitos do conjunto $B$ (seção Marechal Rondon).

d) Fācies subaquosas, inclusive marinhas, alternan do-se com fácies terrestres, ocorrem nos quatro conjuntos in feriores.

e) As litofäcies associadas às ocorrências de fōs seis marinhos no Subgrupo Itararē são, via de regra, cons tituídos de siltito ou lamito sîltico.

f) 0 padrão de distribuição da direção das paleo correntes, notadamente, nos conjuntos inferiores ( $A$ e $B$ ) não mostrou um padrão consistente, enquanto que no conjunto $D$ hă uma pequena incidência de valores voltados para sul (SANTOS, op. cit.).

g) Finalmente, no que se refere ao conjunto E, as suas maiores espessuras acompanham as maiores espessuras do Subgrupo Itararé, exceção feita ao perfil medido ao longo da rodovia SP-281, no qual a parte superior da Formação Tatuí acha-se truncada pela intrusão do"sill" de Taquarituba.

A relação entre os conjuntos litológicos reconhec dos e outras subdivisões litoestratigrāficas propostas para 
- Grupo Tubarão (BARBOSA \& ALMEIDA, 1949a, b; BARBOSA \& GO MES, 1958; ANDRADE \& SOARES, 1971; SOARES \& LANDIM, 1973 e SOARES et al., no prelo) é de difícil entendimento, tendo em vista os diferentes critérios e as escalas utilizadas.

BIOESTRATIGRAFIA. A composição e sucessão faunīs tica e megaflorística do Neopaleozóico da Bacia do Paraná foram tratadas recentemente, por ROCHA-CAMPOS \& ROSLER (no pre 10), enquanto a distribuição da microflora foi discutida por DAEMON \& QUADROS (1970), em grande parte, com base no estudo de amostras de subsuperfície.

0 presente trabalho oferece, contudo, a oportunida de de melhor visualizar a distribuição estratigráfica das diversas assemblēias fossilîferas conhecidas, das litofácies a elas associadas e das biofäcies que thes correspondem.Quan to à composição das assemblēias faunisticas e floristicas a discussão abaixo baseia-se, fundamentalmente, em ROCHA-CAM POS \& RÖSLER (op. cit.), variando, somente, o contexto estra tigräfico utilizado.

\section{Fauna}

Trēs (ou quatro) assemblēias faunísticas foram re conhecidas atē o presente no subgrupo Itararé, duas delas a sociadas aos conjuntos litológicos B-C e uma ao conjunto D. As informações bioestratigräficas palinolōgicas indicam que se tratam de intercalações marinhas, de três idades distin tas, associadas, às Microfloras I, II e III. 0 poder de re solução da anālise palinológica, não permite ainda entender a correlação entre as ocorrēncias fossilīferas associadas à Microflora II, tendo em vista o grau de pormenores atingido atē o presente na identificação das formas encontradas. Dada a pequena distāncia estratigräfica e geogräfica foram elas consideradas como representando a mesma assemblëia. 
Do ponto de vista paleoecológico, os fósseis conhe cidos caracterizam uma biofácies de āguas razas, ou de plata forma interna (SANTOS, op. cit.). As litofácies associadas são, via de regra, constituídas de siltito ou lamito sīitico, mal estratificado ou mesmo maciço, que podem estar associa dos, direta ou indiretamente, a sedimentos de origem glacial (Figuras 6 e 7). Estas relações estratigräficas fazem notar que os organismos originais viviam, provavelmente, sob condi ções de āguas frias, glaciais, possivelmente, nas proximida des de calotas flutuantes (ANDERSON, 1972).

Assemblēia de Araçoiaba. Trata-se de uma assem blëia constituīda, predominantemente, de foraminíferos arenā ceos, incluindo espécies de Hyperammina, Ammodiscus, Brunsielza, Textularia e Reophax, associados a escamas, espinhos e co prólitos de peixe do tipo "enterospira". Os foraminíferos ocorrem em concreções calcārio-fosfāticas e dispersos no la mito (LIMA et al., no prelo), situado, estratigraficamente, um pouco abaixo da parte mëdia da seção, fazendo parte do to po do conjunto B (Figuras 6 e 7 ).

Assemblēia de Capivari-Hortolândia. Constitui a assemblēia faunistica mais diversificada reconhecida atē o presente no subgrupo Itararé.

Em Capivari, a assemblëia inclui os bivalves Limipecten capivariensis (Mendes), Phestia sp.streblopteria sp., alēm de outros indetermināveis, os braquiōpodes

Attenuatelza sp., e Rhynchopora grossopunctata Mendes, e - gastrópode Peruvispira delicata Chronic, alēm de colunais de crinōides (MENDES, 1952; ROCHA-CAMPOS, 1966, 1970). Uma possivel extensão do siltito fossilífero ocorre cerca de 32 km ao norte, na estrada que fazia ligação entre a Via Anhan guera a Hortolāndia. Uma exposição local de siltito, em po sição estratigräfica equivalente, foi, tambēm, observada na 


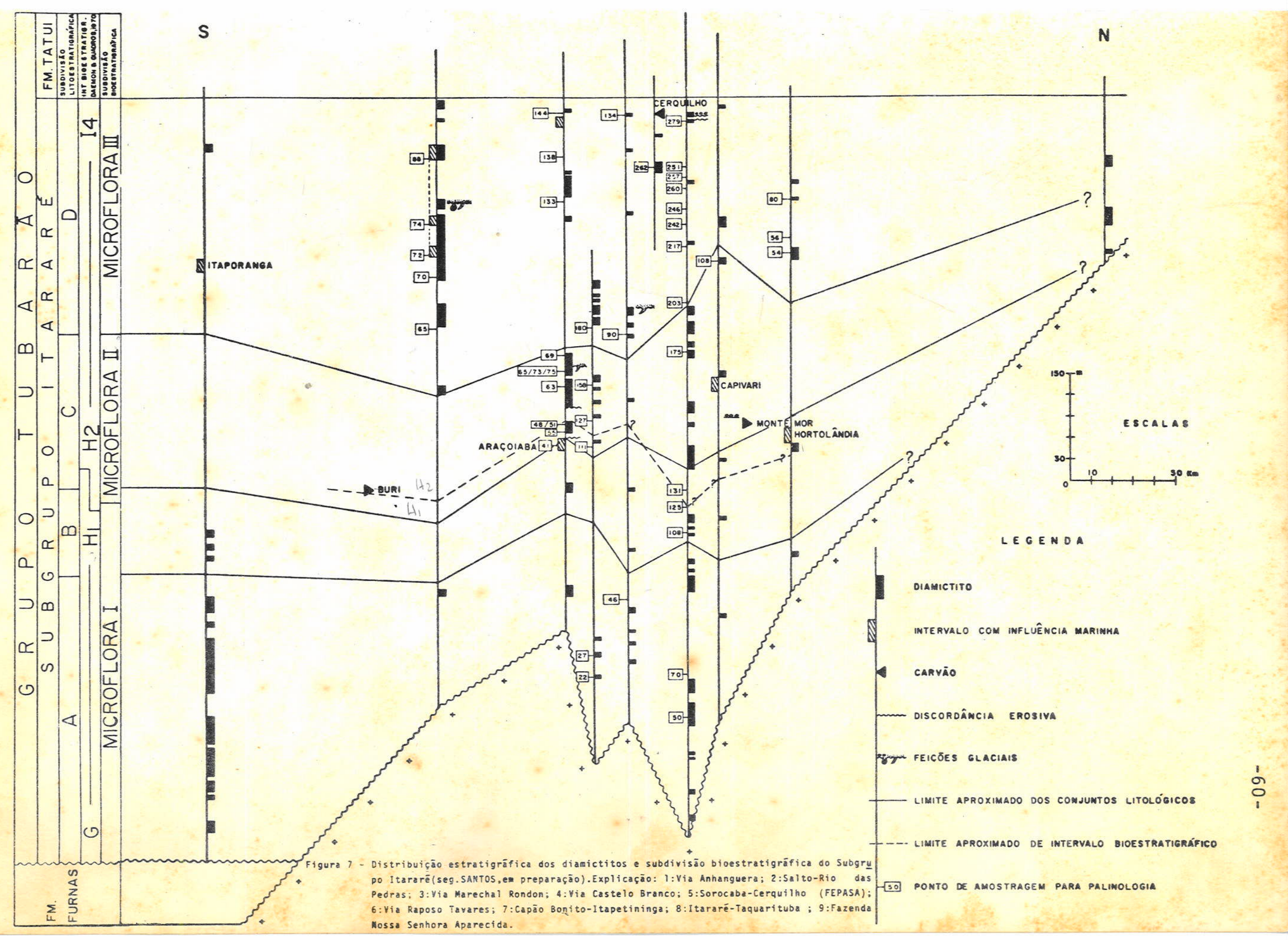


a 1 tura do $\mathrm{km} 111,3$ da Via Anhanguera (Ponto 27, Figura 6). Em Hortolāndia, foram identificadas, somente, espēcies de Phestia, Nuculopsis, Edmondia (?) e foladomídeo indeterminado (ROCHA-CAMPOS \& ROSLER, op. cit.).

As duas ocorrências acima situam-se,estratigrafica mente, muito próximas entre si, embora, aparentemente, fazen do parte de conjuntos litolögicos distintos ( $C$ e B, respecti vamente; Figura 6). Tendo em vista evidências de ordem pa leontolögica disponíveis, preferi considerá-las como equiva lentes.

Assemblëia de Itaporanga. A fāunula de Itaporanga foi, inicialmente, registrada por MEZZALIRA (1956), em silti tos aflorantes junto ao Rio Verde, que reconheceu a presença do bivalve Nuculana. Zimai Mezzalira e do braquiōpode Orbicu loidea cf. guaraunensis 01 iveira.

Siltitos estratigraficamente equivalentes, examina dos durante o levantamento do perfil Itararé-Taquaituba,ocor rem a aproximadamente $3 \mathrm{~km}$ da saída da cidade de Itaporanga, em direção à Coronel Macedo, na parte superior do Grupo Tuba rão, pertencentes ao conjunto $D$ (Figuras 6 e 7 ).

\section{Flora}

A composição e sucessão das megafloras do Grupo Tu barão, na Bacia do Paranā, foi discutida por ROLLER (1973). Duas são as assemblēias conhecidas no Subgrupo Itararē, na ārea em estudo. Em ambos os casos, estão associadas a sedi mentos carbonosos, ou mesmo, camadas finas de carvão, junto a Monte Mör e Cerquilho. Outras ocorrēncias de megaflora no Grupo Tubarão, no Estado de São Paulo, registrados na 1 i teratura (BARBOSA \& ALMEIDA, 1949a), não foram atē o presen te novamente localizadas. 
Assemblēia de Monte Mōr. Trata-se da ocorrēncia mais baixa, estratigraficamente, de megaflora na ārea de e tudo. Os fósseis ocorrem em siltitos, que constituem a capa da camada de carvão, aflorante no Sĩtio de Mina, em Monte Mör. De acordo com revisão recente (MILLAN, 1972, 1974,1975) ela contēm: Lepidodendron pedroanum, Lycopodiopsis sp. Lycopodiopsis pedroanus, Lycopodiopsis derbyi, Rhacopteris cf. chubutiana, Rhacopteris cf. ovata (=Pseudorhacopteris), Botrychiopsis sp.plantiana, Noeggerathiopsis hislopii, Para caiamites australis, alēm de outras formas. RIGBY (1970) no tou a presença de "folhas torcidas" de Glossopteris na assem blēia, porém MILLAN (1975) não incluiu esse gēnero em sua 1ista, interpretando a flora como pré-Glossopteris, e de ida de neocarbonifera (= Tafoflora A de ROSLER, 1973). Os silti tos fossiliferos situam-se, estratigraficamente, na parte in ferior da seção (Figura 7), correspondente, aproximadamente, $\bar{a}$ base do conjunto $C$.

Assemblēia de Cerquilho. As primeiras glossopterí deas reconhecidas, até o presente, no Grupo Tubarão, ocorrem em Cerquilho, em estratos pertencentes à parte superior do Subgrupo Itararē, aflorantes a $6 \mathrm{~km}$ ao sul da cidade de Cer quilho, nos arredores do bairro de Itapema (= Tafoflora tran sicional de ROSLER, no prelo), a menos de $40 \mathrm{~m}$ abaixo do contato com a Formação Tatuí (Figura 7). A lista preliminar divulgada por DOLIANITI \& MILLAN (1972) inclui GLossopteris, Gangamopteris, Noeggerathiopsis e provāveis conifferas do ti po Paranocladus. ROCHA-CAMPOS \& ROSLER (op. cit.) informam que a presença de Glossopteris não foi confirmada em cole ções subsequentes obtidas neste local. 


\section{Microflora}

A primeira tentativa de subdivisão bioestratigrāf ca da sequência neopaleozóica da Bacia do Paranā, incluindo a ārea em estudo, foi realizada por DAEMON \& QUADROS (1970).

Com base na distribuição de esporomorfos dos gru pos Saccites, Monoletes e Monocolpados e de formas atribuí veis às Tasmanales, os autores propuseram a subdivisão da sequéncia neopaleozóica em seis intervalos maiores, denomina dos de baixo para cima, G-H-I-J-K-L. Na ārea paulista da Ba cia do Paranā, o Grupo Tubarão abrangeria os intervalos G- $\mathrm{L}_{\uparrow}$ (parte basal do intervalo L).

DAEMON \& QUADROS (op. cit.) utilizaram, em grande parte, amostras de subsuperfície, tendo sido processadas, so mente, amostras de um afloramento (Pedreira de Itu), da ārea em estudo. Nestes termos, pode-se considerar ainda precārio - controle bioestratigráfico existente para a correlação en tre subsuperfície e superfície, mormente, levando-se em con ta os modelos de sedimentação propostos na literatura para 0 Subgrupo Itararé, que implicam em ciclos sucessivos e a in cidencia de fases de erosão e retrabalhamento dos sedimentos (FRAKES \& CROWELL, 1972). Assim sendo,e no sentido de propi ciar um controle adequado para a correlação das seções estu dadas, o levantamento de campo foi acompanhado de extensiva coleta de amostras de litologias adequadas para o processa mento palinológico.

A utilização, por DAEMON \& QUADROS (op. cit.), prin cipalmente, de formas dos três grupos taxonōmicos citados, constitui, tambēm, uma limitação, jā que os palinomorfos atri bữveis aos pōlens são, geralmente, considerados como mais sus cetîveis de exibir variação vertical.

Cerca de 200 amostras de litologias diversas 
foram coletadas e processadas de acordo com a técnica descri ta anteriormente (p. 21), das quais, 70 mostraram-se férteis. As formas isoladas foram identificadas, preliminar mente, ao nĩvel de gênero,e sua distribuição vertical e geo grāfica determinada. A distribuição das formas mais comuns e de amplitude restrita serviu de base para o reconhecimento da constituição das principais microfloras do Subgrupo Itara ré, em termos qualitativos e quantitativos.

os resultados obtidos estão exibidos nos gräficos das Figuras 8 e 9 . A primeira representa a distribuição ver tical de todas as formas (gêneros) de algas, esporos e pōlens identificadas nas amostras coletadas ao longo dos perfis exa minados. A segunda, sintetiza as características quantitati vas das trēs microfloras identificadas, que do ponto de vis ta bioestratigräfico, caracterizariam intervalos, provavelmen te,correspondentes a zonas de associação, que serão descri tas abaixo. Obviamente, o gräfico correspondente à Figura 8 não é completo em relação a todos os gēneros de esporos e pólens atē agora identificados no Subgrupo Itararē, no Esta do de São Paulo, pois baseou-se na determinação de material proveniente, somente, das seções examinadas. Pōlens bissaca dos estriados foram identificados em amostras da Pedreira de Itu (DAEMON \& QUADROS, op. cit.; KEMP, 1973), o que também foi confirmado durante a presente pesquisa.

Microflora I. A microflora mais antiga identifica da no Subgrupo Itararē corresponde, litoestratigraficamente, aos conjuntos $A-B$.

Caracteriza-se ela, por uma predomināncia de espo ros, que podem atingir até $80 \%$ (em mëdia), acompanhados por quantidades subsidiārias de pölens dos tipos monossacados (até cerca de 20\%), monocolpados (até 2-3\%) e bissacados sim ples e estriados (atë cerca de $3 \%$ ). 

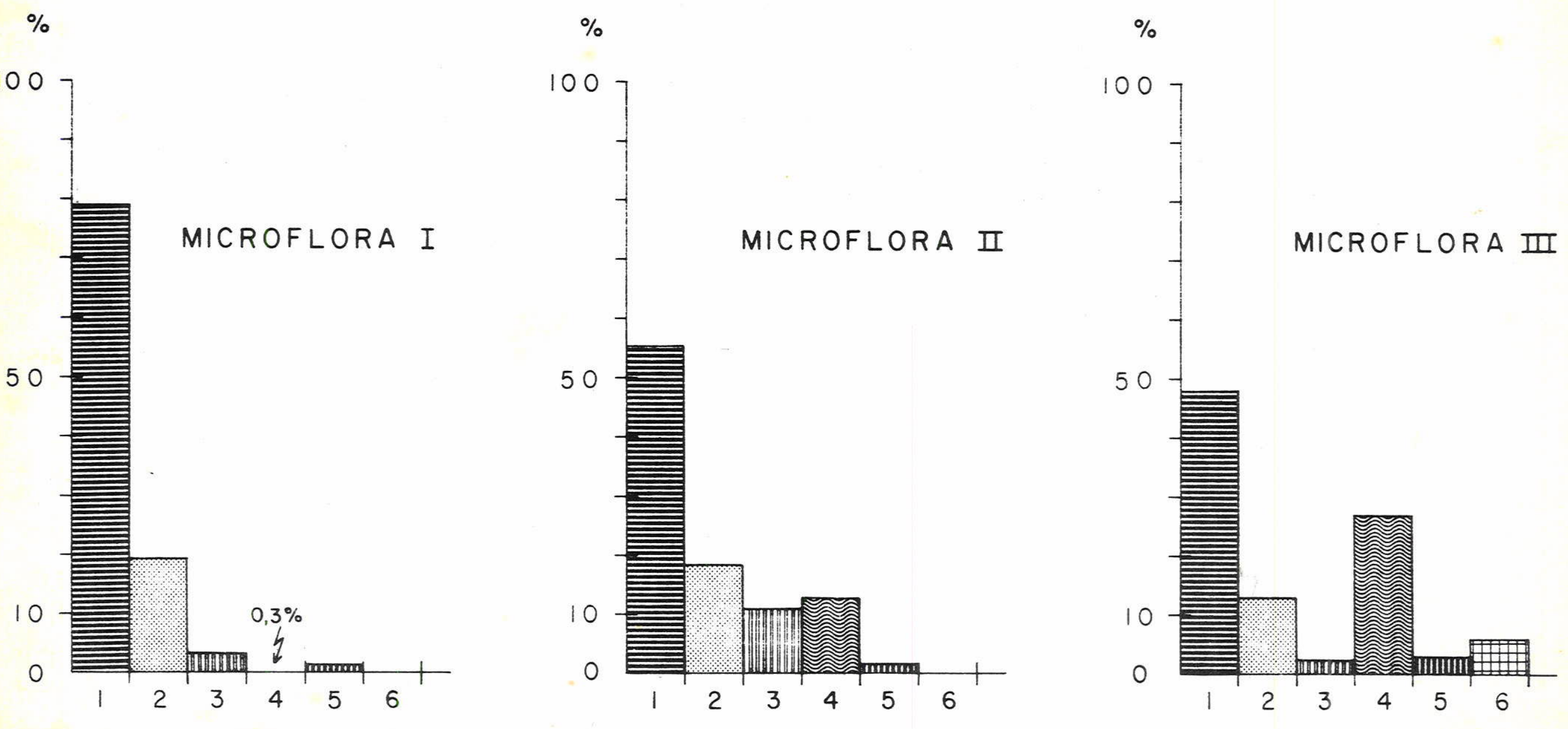


\section{SUBGRUPO ITARARÉ}

\begin{tabular}{|c|c|c|c|}
\hline A & B & C & D \\
\hline MICROFLORA I & MICROFLORA II & MICROFLORA III \\
\hline
\end{tabular}

SUBDIVISĀO LITOES TRA TIGRÁFICA SUBDIVISATO BIOESTRATIGRÁFICA $\mathbf{G} \mathrm{H}_{\mathbf{1}}$ $\mathrm{H}_{2} \longrightarrow \mathrm{I}_{4}$ 4

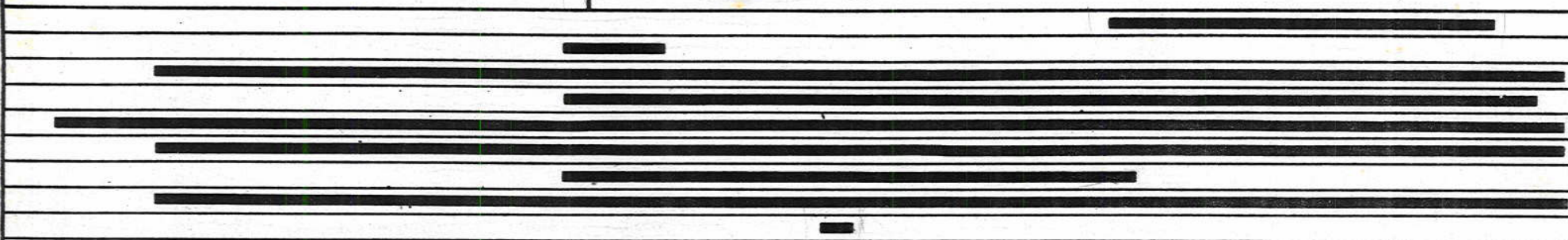
INT. BIOESTRATIGRÁFICO (DAEMON \& QUADROS, 1970) TASMANITES ALGA VERRUCOSOSPORITES PUNCTATOSPORITES LAEVIGATOSPORITES PUNCTATISPORITES CALAMOSPORA

RETUSOTRILETES LEIOTRILETES MICROBACULISPORA? RAISTRICKIA ACANTHOTRIA ETES ACANTHOTRILETES LOPHOTRILETES APICULATISPORITES PUSTULATISPORITES VERRUCOSISPORITES GRANULATISPORITES CYCLOGRANISPORITES BROCHOTRILETES VALLATISPORITES KRAEUSELISPORITES LYCOSPORA DENSOSPORITES PINGULIZONATES POTONIEISPORITES ALISPORITES VESTIGISPORITES PLICATIPOLLENITES VIRKKIPOLLENITES PARASACCITES FLORINITES STRIOMONOSACCITES SROTOHAPLOXYPINUS PROTOHAPLOXYPINUS VATANA TAENIAESPORITES HAMIAPOLLENITES STRIATOABIE TITES

Distribuiçāo dos gênerós de palinomorfos do Subgrupo Iatararé.

Fia 8 
Microflora II. A Microflora I é sucedida por uma outra assembléia de carāter transicional, mais diversificada, onde se nota jā um decrēscimo da frequência de esporos, cuja porcentagem média baixa até cerca de $5 \%$ Acompanham-nos pō lens monossacados e monocolpados, cuja frequéncia total é equivalente ao da Microflora I, e bissacados simples e es triados, cujas porcentagens mēdias jā ultrapassam 10\%. Gêne ros característicos e, aparentemente, limitados a este inter valo correspondem aos esporos Verrucososporites, Microbaculis pora (?), Pustulatisporites, Brochotriletes e pólens Striatoabietites e Alisporites. Litoestratigraficamente, a assembléia caracteriza o conjunto $C$.

Microflora III. A assemblēia,estratigraficamente, mais jovem do Subgrupo Itararé, correspondente ao conjunto $D$, exibe um decréscimo acentuado da porcentagem de esporos ( < 50\%, em média) e de bissacados simples, em relação à an terior. De outro 1 ado, os bissacados estriados, aparecem com frequéncias elevadas (mēdia de cerca de $30 \%$ ). A porcentagem de monossacados baixa, ligeiramente, enquanto o contrārio sucede com os pólens monocolpados. A presença de formas atri buỉveis às Tasmanales, constitui uma feição notāvel da assem bléia, da qual podem perfazer pouco mais de $5 \%$.

Alēm de Tasmanites, esporos dos gēneros Cyclogra nusporites, Lycospora, parecem ser privativas deste interva 10, juntamente com pólens atribuĩveis a Hamiapolzenites.

No momento, pouco pode ser dito com relação às pos síveis relações entre as subdivisões propostas e as discuti das por DAEMON \& QUADROS (op. cit.), em grande parte, tendo em vista os diferentes critérios taxonōmicos utilizados no presente trabalho, do que resulta uma inconsistēncia tempo rāria na nomenclatura das formas reconhecidas e utilizadas. Somente, uma revisão direta do material manuseado por aqueles autores poderā permitir um cotejo mais pormenorizado. Assim 
mesmo, tentou-se uma correlação aproximada, conforme estā exibido nas Figuras 7 e 8 .

IDADE. 0 problema da idade da sequéncia neopaleo zóica, inclusive o Grupo Tubarão aqui tratado da Bacia do Pa rănă, em relação à escala padrão mundial constitui um proble ma ainda não solucionado a contento.

ROCHA-CAMPOS \& RÖSLER (op. cit.) revisaram, recen mente, os dados megafaunisticos e mega e microfloristicos re lativos ao problema, que consideram, como parece ser ōbvio, intimamente relacionado a questão da fixação do limite Carbo nīfero-Permiano no Hemisfério Sul, no geral, e na América do sul, em particular.

Em sintese, as conclusões atingidas por aqueles au tores podem ser assim apresentadas. No nosso caso, limitar-me-ei a discutir, somente,os dados referentes ao Subgrupo Itararé, jā que nenhuma nova ocorrēncia foi encontrada em rochas da Formação Tatuí:

1) os invertebrados marinhos que ocorrem no Grupo Tubarão permitem, somente, o estabelecimento de uma idade ge ral Permiana para parte do Subgrupo Itararé (abrangendo,pelo menos, a sequéncia acima da assembléia de Capivari), sendo o limite superios fixado pela idade eopermiana (artinskiana) atribuīda à assemblēia marinha de Taiō, na parte média da Formação Bonito, em Santa Catarina (ROCHA-CAMPOS, 1970; RUN NEGAR, 1972). Com relação ao limite inferior a ünica infor mação disponível refere-se à assemblēia de Araçoiaba, para a qual LIMA et al. (op.cit.) sugeriram uma idade neocarbonife ra.

A correlação proposta entre as assemblēias de Cap $\underline{i}$ vari e Hortolāndia sugere uma "transgressão" temporal da ba se do Subgrupo Itararē em direção NE, no Estado de São Paulo, onde estaria representado, somente, a parte superior do sub 
grupo.

2) Quanto à megaflora, tem sido convenção geralmen te aceita no Hemisfério Sul, considerar-se o início do Per miano, coincidente com o aparecimento das primeiras Glossop terídeas, ou do ponto de vista prātico, a primeira ocorrên cia de Gangamopteris (ARCHANGELSKY, 1971; RÖSLER, 1972,1973).

Na Argentina, assemblēias com Glossopterídeas são precedidas, estratigraficamente, por megafloras contendo Pseudorhacopteris ovata (assemblëia Tupense) e Botrychiopsis plantiana (assemblēia Trampeaderense), que ARCHANGELSKY (1971) conșidera de idade neocarbonĩfera. A ūitima espécie coexis te, em parte, com as primeiras ocorrēncias de Glossopterídeas (ARCHANGELSKY, 1971).

Na Bacia do Paranā, MILLAN (1975) identificou Pse u dorhacopteris cf. ovata e Rhacopteris cf. chubutianal=Pseu dorhacopteris ?), na assemblëia de Monte Mōr, portanto, den tro da ārea em estudo. Como jā comentei, esse autor não re conheceu a ocorrēncia de impressões de Glossopteris nessa flora, anteriormente mencionada por RIGBY (1970), consideran do-a como prē Glossopteris, e nesse caso, de idade Carbonífe ra (vestfaliana). As primeiras ocorrēncias de Glossopterídeas no Grupo Tubarão foram registradas na Assemblëia de Cerqui 1ho, na parte superior do Subgrupo Itararē, o que, de acordo com o ponto de vista tradicional, coincidiria com o inicio do Permiano (RŐSLER, 1973).

RIGBY (1973), contudo, descreve a sucessão de mega floras neopaleozóicas de Queensland, Austrālia, em que assem blëias com Pseudorhacopteris e Botrychiopsis são sucedidas por floras eogondvânicas típicas com Glossopterideas no in tervalo Namuriano-Eopermiano.

3) Microflora. De acordo com a interpretação de DAEMON \& QUADROS (op. cit.) os intervalos bioestratigrāfi $\cos$ G a L, que corresponderiam à sequência Tubarão, no Está 
do de São Paulo, seriam equivalentes cronologicamente ao Es tefaniano C - Kazaniano, isto è, neocarbonífero-neopermiano. Tal interpretação, evidentemente, colide, em parte, com a an teriormente discutida referente aos dados baseados nos inver tebrados marinhos jā que a idade artinskiana atribuīda à as semblēia de Taiō, estabeleceria, aproximadamente, esse limi te superior (eopermiano) para a idade do Subgrupo Itararé.

os dados palinológicos obtidos durante o decorrer do presente trabalho, referentes, somente, ao Subgrupo Itara ré, foram comparados com outras sequências de microfloras neo paleozöicas conhecidas no Gondvana, particularmente, da Aus trália, onde se associam à ocorrēncia de fósseis marinhos diagnōsticos, o que permitiu a fixação de suas idades aproxi madas, em termos da coluna padrão mundial.

0 confronto com as assemblēias ("Andares") de EVANS (1969) e de SEGROVES (1970) forneceu resultados aproximada mente iguais, isto $\bar{e}$, as Microfloras I, II e III, reconheci das no Subgrupo Itararē, são comparāveis, quantitativa e qua 1 itiativamente, comas microfloras 2-3 de EVANS (1969) e comas assemblëias de Microbaculispora a Haphocystia de SEGROVES (1970), correspondente ao intervalo neocarbonifero-eopermiano (a neopermiano ?). KEMP (1973) processou, tambēm, seis amostras de diamictitos, ritmitos e siltitos do subgrupo Ita raré, da ārea paulista, obtendo assemblēias palinolögicas que considerou comparāveis às microfloras 2-3 de EVANS ( op. cit.), o que coincide com as conclusões aqui atingidas.

Um comentário, poderia ainda ser feito, com rela ção à idade dos sedimentos do Subgrupo Itararē, da região nor deste do Estado de São Paulo, denominados por alguns autores Formação Aquidauana (ALMEIDA, 1954, 1956; LANDIM, 1970, SOARES, 1972; SOARES \& LANDIM, 1973; FIORI, 1977), em relação aos se dimentos glaciais da parte central e sul do Estado. ALMEIDA (1954) considerou-os mais novos do que o Itararē, correla 
cionando-os com a sequência pös-glacial (Formação Itapetinin ga). LANDIM (op. cit.) e SOARES \& LANDIM (op. cit.) concor daram com ALMEIDA (1956), quanto à correlação das rochas exis tentes em Aguas da Prata, Poços de Caldas e sul de Minas Ge rais e as da Formação Aquidauana, de Mato Grosso e Goiās.Con tudo, admitiram que os sedimentos da borda leste devessem ter a mesma amplitude de idade que a Formação Itararē, em razão do seu interdigitamento, tanto na base como no topo. Segundo esses autores, tais relações podem ser observadas na região de Leme, em direção a Conchal e Mogi-Guaçu. Entretanto, geō logos da Petrobrās, baseados em dados palinolōgicos, são a favor de uma idade mais velha para o Aquidauana, da borda oeste, em relação ao Subgrupo Itararē, do Estado de São Pau 10 (NORTHFLEET, MEDEIROS \& MÜHLMANN, 1969; DAEMON \& QUADROS, $1970)$.

Do exame das Figuras 6 e 7, trēs hipōteses parecem ser possĩveis quanto as relações estratigrāficas entre o sub grupo Itararē nas regiões nordeste e central do Estado. Tais formulações baseiam-se, fundamentalmente, em evidências lito estratigrāficas, dada a ausência de controle paleontolögico dispo nível. A primeira seria de que, tanto os sedimentos da base do topo do Subgrupo Itararé, da parte nordeste, como os da re gião central e sul, ter-se-iam depositados contemporaneamente e que a posição dos primeiros, exibida nos gráficos menciona dos, decorreu de basculamento tectōnico do embasamento da re gião nordeste, conforme comentarei adiante. A segunda, se ria de que os sedimentos a nordeste, corresponderiam aos da parte basal do subgrupo, nas regiões centro-leste e centro-sul. De maneira similar, estariam em posição topogräfica alta, devido ao levantamento ocorrido na parte marginal da Bacia, ao tempo da deposição do conjunto C. A terceira pos sibilidade, que prefiro, admite que os sedimentos a nordeste seriam equivalentes, somente, aos da parte superior do sub grupo Itararē (conjuntos C e D). Esta hipōtese fundamenta- 
-se na ocorrência de fácies avermelhadas ("Formação Aquidaua na"), em posição estratigräfica superior à da intercalação má rinha de Hortolândia, Capivari (e tambēm superior ao conjun to B), em Leme (LANDIM, op. cit.; SOARES \& LANDIM, op. cit.), e, portanto, correspondendo, cronologicamente, a idade da Microflora III.

Recentemente, PASCHOLATI \& PACCA (no prelo) suge riram, atravēs de estudos paleomagnéticos de rochas do sub grupo Itararé de Mococa, Casa Branca e Araçoiaba, serem as sequências a nordeste mais jovens do que as basais da região centro-sul do Estado, o que corroboraria a interpretação ado tada. 


\section{6 - HISTÓRIA TECTO-SEDIMENTAR}

0 desvendamento da histōria tecto-sedimentar de uma unidade complexa como o Grupo Tubarão, particularmente, a do Subgrupo Itararēè, como se pode perceber pela descrição que precedeu, dificil, dada a complexidade do arranjo espacial das suas litologias, tanto na vertical, quanto na horizontal e o ainda precārio controle bioestratigräfico disponỉvel.

Assim mesmo, creio ser possivel atingir-se algumas inferências gerais quanto à histōria sedimentar e os fatores tectônicos principais que a controlaram.

A natureza continental da glaciação que afetou a Ba cia do Paranā, jā adequadamente comprovada (LEINZ, 1937; ROCHA-CAMPOS, 1967; MARTIN, 1961, LANDIM, 1970), em particular, na ārea em estudo, implica, segundo o ponto de vista atualîs tico, ao meu ver, na possibilidade de atuação de fatores tec tônicos anālogos aos que condicionaram a sedimentação dos de pósitos da glaciação pleistocênica. Esta, como é do conhecimento geral, tem carāter cíclico, envolvendo episódios de avanço e recuo do gelo, que são acompanhados, respectivamente, pelo maior e menor acümulo de gelo sobre a crosta da Ter ra, e de ajustes isostāticos e eustáticos negativos e positi vos, na ārea afetada pela glaciação.

Ao mesmo tempo, é bastante provāvel que a sedimenta ção do Grupo Tubarão tenha estado tambēm condicionada por fá tores tectônicos regionais, que acompanham o desenvolvimento de uma bacia intracratônica, como é o caso da Bacia do Paranā.

A medida que a atual pesquisa desenvolveu-se tornou-se, mais ou menos claro, que a elaboração de um "modelo" tecto-sedimentar para o Grupo, envolvia, pelo menos, os dois conjuntos de fatores, acima apontados, cujos efeitos se in- 
terpenetram, não sendo sempre possĩvel de discernimento. Não constitui objetivo desta dissertação elaborar, pormenorizada mente, este ponto, porém creio que devo dedicar algumas 1inhas à discussão de conceitos tectônicos gerais que nortearam a tentativa de anālise que se segue.

Tendo em conta que o painel estratigräfico obtido representa, ainda que grosseiramente, um panorama da sedimen tação da unidade tratada ao longo da direção deposicional, a anălise intentada fundamenta-se na possibilidade de se reconhecer os traços principais da histōria tecto-sedimentar, através do exame das variações laterais das características litológicas e texturais da sequencia em estudo. Essas variações de carāter regional, no meu entender, refletem condições tectônicas também regionais e de carāter cratônico.

Internamente, a sequência examinada encerra outras evidências litológicas e estratigräficas, que parecem refletir a ação de fatores mais locais e de expressão lateral variāvel. Encaixam-se aqui, as sequências particulares de lito logias que podem repetir-se na vertical, simulando ciclos (LEINZ, 1937; FRAKES \& FIGUEIREDO, 1967; LANDIM, 1971; SANTOS et al., 1973). Estes, ao meu ver, constituem reflexo de fenômenos epirogenéticos, de carāter isostático,ligados à evolução da glaciação.

Na atual discussão, reportar-me-ei, somente,aos fenômenos tectônicos sedimentares de magnitude maior, jā que os do segundo grupo deverão ser tratados, com mais pormenores, por SANTOS (op. cit.) ).

Do exame do painel estratigräfico, levando-se em conta as características litológicas e texturais gerais dos conjuntos litológicos reconhecidos (Figuras 6 e 7 ), parece evidente que a histōria tecto-sedimentar do Grupo Tubarão,no Estado de São Paulo, envolveu, pelo menos, quatro fases dis- 
tintas.

A primeira, abrange desde a ēpoca prēvia à deposição do conjunto $A$, até o final da deposição do conjunto $B$. Caracteriza-se, inicialmente, por um periodo de intensa atividade tectōnica, principalmente, na região centro-sul (SANFORD \& LANGE, 1960; PETRI \& FULFARO, 1967; LANDIM,1970,1972; FULFARO, 1971, 1974).

De fato, a ausēncia de camadas devonianas ao norte de Itapeva e as evidēncias de retrabalhamento dos arenitos da Formação Furnas, desde essa localidade, em direção à parte sul do Estado, sugerem a existēncia de um embasamento prē - Tubarão constituĩdo de āreas elevadas, na região das cidades de Capão Bonito e Sorocaba e deprimidas em direção à região de Itararē. 0 levantamento dessa ārea, segundo PETRI \& FULFARO (1967) e FULFARO (1971), esteve associada a uma fase de falhamentos normais, que corresponderia a um ciclo tectónico de idade pōs-devoniana e prē-neocarbonífera. Posteriormente, FULFARO (1974) reconheceu evidéncias de uma intensa atividade tectōnica ao longo do que denominou alinhamento es trutural do Paranapanema, orientada segundo,ESE - 0 NO, na época de sedimentação do Subgrupo Itararē. Ainda, segundo este autor, tal feição estrutural dividiu a Bacia do Paranā em duas sub-bacias das quais, a setentrional, teria tido carāter mais subsidente. Anteriormente, SANFORD \& LANGE(op. cit.) jā haviam reconhecido o Arco de Ponta Grossa como elemento estrutural responsāvel por uma compartimentação longitudinal da Bacia ao tempo Tubarão. LANDIM(op. cit.), atravēs de uso de tēcnicas de anālise de tendēncias de superfīcie aplicada a dados de espessura do Grupo,verificou, ainda, a existência de altos regionais intrabassinais nas regiões de Apucarana e 01 impia, que teriam influenciado a sedimentação neopaleozōica.

A partir desses dados e levando-se em conta o apa- 
rente comportamento do embasamento revelado pelo exame da Fi gura 6 , pode-se imaginar que o inĩcio da sedimentação do Grü po Tubarão na ārea (conjunto A) ocorreu, provavelmente,sobre um embasamento de topografia irregular, com regiões intrabas sinais deprimidas de orientação geral SE-NO(vale do Rio Tietê, região de Itararé e, localmente, a região de Sorocaba) e elevadas (região de Capão Bonito e Sorocaba e ao norte de Campinas), que se estendiam, ao que parece, até a região mar ginal atual da Bacia. Tais feições foram responsāveis, em par te, pela variação lateral de fācies verificadas no conjunto inferior, ao longo da direção deposicional, e sua distribuição e carāter ao longo da margem leste, poderiam ser responsāveis pelo padrão de distribuição dos diamictitos, abrangen do maior incidência, tanto em número, quanto em espessura, associadamente, às āreas de maior espessura e mais subsidentes do Grupo Tubarão, contrapondo-se as espessuras menores e menor nūmero de corpos, correspondentemente as āreas de menor espessura e subsidência.

Na Figura 10, estão representados, esquematicamente, os principais elementos tectônicos que, no meu entender,condicionaram a sedimentação do Grupo Tubarão.

Apōs a deposição do conjunto $A$, a sub-bacia norte parece ter alcançado um período de relativa calma tectônica, fazendo com que, fenômenos isostāticos, relacionados ao meca nismo de avanço e recuo das geleiras, presentes desde o inicio da sedimentação, tornem-se, relativamente,predominantes. Isto pode ser evidenciado pelas caracterĩsticas texturais do conjunto B (porcentagem maior de clásticos finos) e pelo registro de intercalações marinhas.

A segunda fase, abrangendo parte do conjunto $C$, caracteriza-se, principalmente, pelo recrudescimento de condições tectônicas. Nesta época, provavelmente, teve inỉcio um levantamento gradual da borda nordeste da Bacia, que se man- 


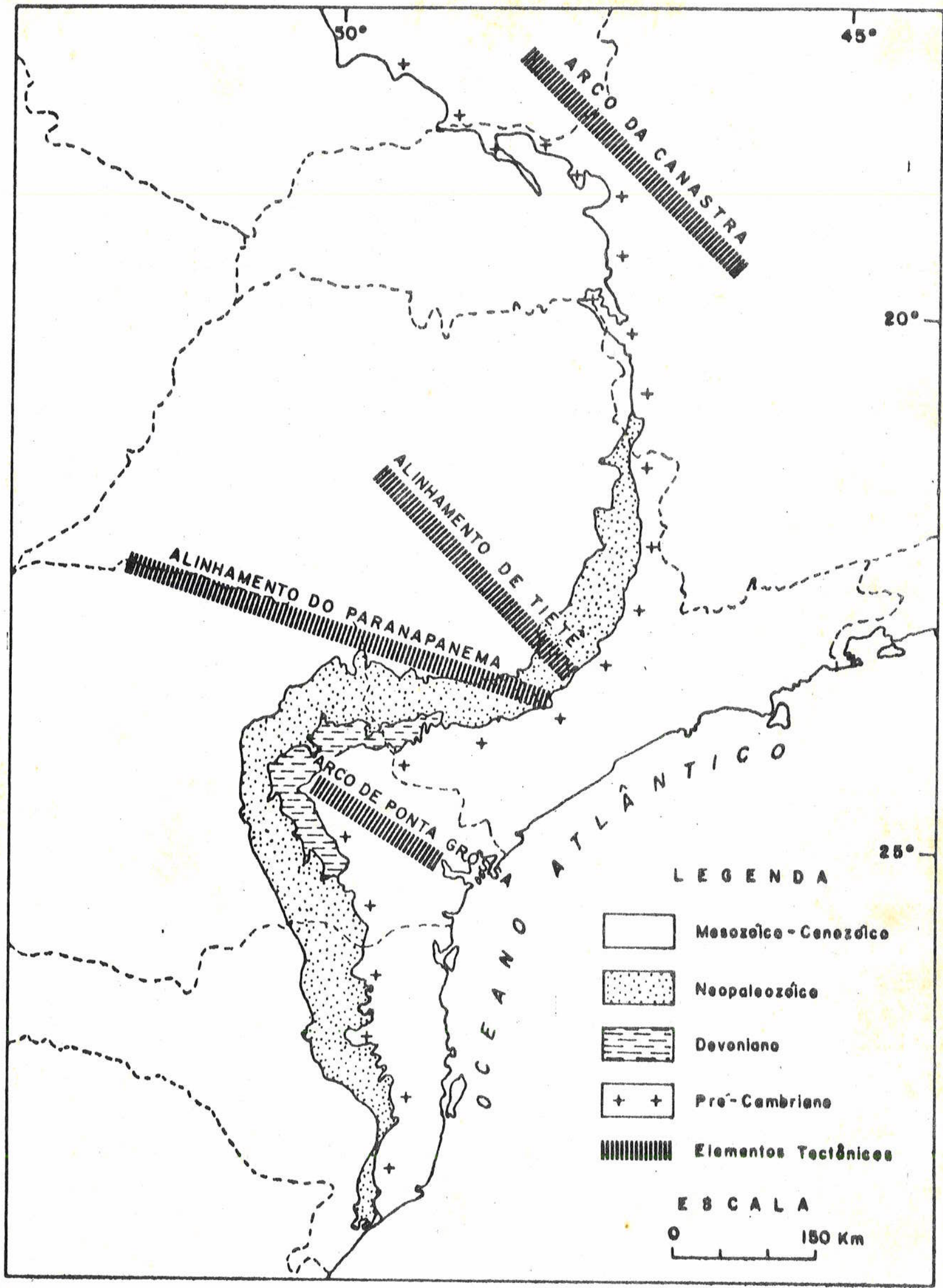

Figura 10 - Principals elementos tectônicos da Bacia do Paranā, durante o Neopaleozöico, na ärea de estudo. 
teve atē o final da deposição do Subgrupo. No geral, predomi nam os clāsticos grossos e diamictitos, notadamente, nas regiões centro-sul e nordeste, enquanto que, na região centro- leste os clāsticos grossos e diamictitos associam-se aos clāsticos finos.

$\mathrm{Na}$ terceira fase, verifica-se a deposição da parte superior da sequēncia Itararē (conjunto D),predominando, na região nordeste, sedimentação nitidamente continental,gradan do, em direção ao sul, para condições de maior influência ma rinha. Texturalmente, os sedimentos a nordeste são grossos, enquanto que, nas regiões centro-leste e centro-sul são, pre dominantemente, constituĩdos de clàsticos finos.

Finalmente, a quarta e ūitima fase representada, es tratigraficamente, pela Formação Tatuĩ, corresponde a um perỉodo tectonicamente calmo, haja vista a sedimentação extremamente fina e homogênea dessa sequēncia. 0 inīcio do ciclo pös-glacial pode ter sido erosional (SOARES, 1972), com retrabalhamento do material depositado no ciclo anterior. 


\section{7 - Elementos de paleogeografia}

Com base nos elementos discutidos anteriormente, e em outros dados pröprios e da literatura, apresentarei, a se guir, uma discussão sucinta dos principais traços da geografia glacial neopaleozóica, na parte norte da Bacia do Paraná, abrangida pelo presente estudo.

As reconstituições disponiveis da paleogeografia dos depōsitos glaciais do Subgrupo Itararē, fundamentam-se, principalmente, em dois tipos de evidencias: a) dados relati vos à direção do movimento do gelo, determinados a partir de elementos direcionais verificados nas rochas ou no seu embasamento; e b) natureza das fácies sedimentares e sua distribuição.

ROCHA-CAMPOS (1967) compilou dados da literatura a respeito das feições direcionais associadas aos sedimentos glaciais, mostrando que o sentido principal de transporte foi de sudeste para noroeste, na parte norte borda da Bacia do Paranā. Com base nesses dados e associando-os à distribui ção de fäcies então reconhecidas ao Subgrupo Itararē, ROCHACAMPOS, FARJALLAT \& YOSHIDA (1969b) delimitaram uma ārea de sedimentação, predominantemente terrestre, a leste, que passaria, em direção oeste, para uma região onde teria predominado deposição subaquosa (FARJALLAT, 1970).

Atravēs da medição de paleocorrentes e estrias sobre o embasamento Pré-Cambriano na borda leste da Bacia,FRAKES \& CROWELL (1969) puseram em evidência, novamente, que o sentido principal de deslocamento das geleiras neopaleozōicas e de transporte dos sedimentos do Subgrupo Itararē teria sido de SE-NO, na ārea paulista da Bacia do Paranā. Reconheceram, ainda, que a deposição de morenas basais e atividades fluviais constituiram processos dominantes em três centros 
principais: a) Estado de São Paulo; b) Estado do Paranā, ao sul do arco de Ponta Grossa, e ao Norte de Santa Catarina; c) ao redor do escudo Uruguaio-Rio Grandense.

LANDIM (1970;1972) e FULFARO (1971) chegaram a resultados semelhantes, ao tratarem o ciclo glacial através de tēcnicas de anālises de tendência de superfície. Particularmente, para o Estado de São Paulo, LANDIM (op.cit.) deduziu a presença de uma região tectonicamente negativa,de orientação NO-SE, situada entre duas outras de caráter tectonicamente positivo, denominadas altos de São Jerōnimo da Serra (Parană) e 0limpia, Estado de São Paulo. Tais elementos foram interpretados como centros, a partir dos quais teria havido irradiação glacial.

FRAKES \& CROWELL (1972), com base na coíncidência geral de direção de transporte e contiguidade geográfica pré -deriva,especularam que os lobos glaciais que atingiram a Ba cia do Paranā, Kaokeveld, Paranā e Uruguai, no seu flanco leste, tiveram o seu centro principal de glaciação na região da Zâmbia-Rodēsia-Botswana, na Africa (FRAKES \& CROWELL, 1970 e CROWELL \& FRAKES, 1970, In FRAKES \& CROWELL,op.cit.). Sugeriram, tambēm, que esses lobos situavam-se ao longo dos eixos das depressões mostradas pelos mapas de isoespessura e anälises de tendências de superfĩcie. Assim, o lobo Kaokeveld estendeu-se em direção noroeste no Estado de São Paulo, para lelamente às estrias verificadas no escudo brasileiro.

As intercalações de fōsseis marinhos nos sedimentos do Grupo Tubarão, jā reconhecidas hā muito tempo, constituem outro elemento importante para a interpretação da geografia neopaleozóica da ārea. ROCHA-CAMPOS (1967, 1970) reconheceu a afinidade entre os invertebrados marinhos do Grupo Tubarão e os de faunas neopaleozócas da Argentina, de onde, provave 1 mente, ter-se-iam dispersado em direção norte, para a Bacia do Paranā. Em consonāncia com essa interpretação, FRAKES \& 
CROWELL (1969, 1972) postularam que a conexão marinha da Ba cia do Paranā ter-se-ia situado, provavelmente, em direção sul, entre duas āreas positivas representadas pelo escudo Uruguaio-Rio Grandense e o arco Martin Garcia. (PADULA \& MIN GRAM, 1967.)

Tal interpretação difere da de LANDIM (1970) que, tendo em vista o comportamento tectonicamente negativo, da ärea central do Estado de São Paulo,durante a deposição do Subgrupo Itararē, admitiu que a entrada do mar deveria ter sido de sudeste, na parte norte da Bacia. Tal conclusão foi tambēm adotada por FULFARO (1971), baseado nos resultados de anālises de tendências de superfície aplicada a dados de espessura do Grupo Tubarão.

A integração dos dados disponĩveis na literatura e seu exame à luz das novas informações obtidas, permite a ela boração de um esboço paleogeogräfico de carāter preliminar, para parte norte da Bacia do Paranā, que esclarece alguns dos pontos principais acima tratados. As bases utilizadas pa ra a elaboração desse quadro foram as seguintes:

1) Com relação à direção principal de transporte dos sedimentos durante a glaciação neopaleozóica, os dados fornecidos atravēs de evidências, tais como, superfīcies estriadas, "roches moutonēes", pavimento de clastos, alongamen to de vales glaciais, etc, indicam, sistematicamente, uma direção de transporte de sudeste para noroeste (ROCHA-CAMPOS, 1967 ; FRAKES \& CROWELL, 1969; ROCHA-CAMPOS, FARJALLAT \& YOSHIDA, 1968, 1969a; ROCHA-CAMPOS et al., 1976). Embora,os dados direcionais de estruturas sedimentares observäveis nas rochas do subgrupo Itararé como, por exemplo,estratificações cruzadas, sejam de interpretação complexa (LANDIM,1970; BOUL TON, 1972), as primeiras constituem elementos valiosos para anālise paleogeogräfica não devendo, pois, serem desprezadas.

Neste particular, o exame dos perfis, aqui descritos, 
permitiu verificar que as direções de deslocamentos do gelo neopaleozöico, interpretadas atravēs de estruturas diretamen te relacionadas ao deslise das geleiras, mantiveram-se, aparentemente, constantes durante a deposição do Subgrupo Itara ré. Isto pode ser observado, por exemplo, atravēs das medições de estrias sobre as "roches moutonēes", na base da sequência em Salto (ALMEIDA, 1948; AMARAL, 1965), comparado com as encontradas sobre os pavimentos de clastos intratiliticos na parte mëdia e superior do subgrupo Itararē, em Capivari e Jumirim (ROCHA-CAMPOS et al.; no prelo; ROCHACAMPOS, FARJALLAT \& YOSHIDA, 1968).

2) As ingressões marinhas de Hortolāndia, Capivari, Araçoiaba da Serra e Itaporanga, presentes na sequência glacial, apresentam uma biofácies caracterīstica de mares rasos, inclusive plataforma interna (LIMA et al.; no prelo; SANTOS op.cit.). Situação similar, tambēm, é indicada pelos Tasmanites presentes nos diamictitos da parte superior do Subgrupo Itararē, junto à Gramadinho (CAREY \& AHMAD, 1961).

3) Conforme discutido no capitulo anterior(p.76), a configuração topogrāfica da margem da Bacia do Paranā, no Es tado de São Paulo, parece ter incluĩdo āreas elevadas e deprimidas. As primeiras corresponderiam ao arco de Ponta Gros sa, ao alinhamento estrutural do Paranapanema, que na ëpoca de sedimentação da sequência Itararé atuou,provavelmente, co mo um alto estrutural, e a borda nordeste da Bacia, que poderia representar o prolongamento sul do arco da Canastra. As āreas tectonicamente negativas corresponderiam, ao que pa rece, a um alinhamento de direção NO-SE, jā notada, tambēm, por FRAKES \& CROWELL (1969), LANDIM (1970) e FULFARO (1971), aqui denominada, informalmente, de alinhamento de Tietê. Uma outra área subsidente localizar-se-ia, possivelmente, entre os alinhamentos estrutural de Paranapanema e o arco de Ponta Grossa.Essa topografia deve, pois, ter influenciado o deslise 
das geleiras, que ao meu ver, tiveram o seu fluxo principal condicionado pelas āreas negativas acima mencionadas.

Outros elementos paleogeogräficos de carāter mais regional foram coletados, ainda, atravēs da confecção de mapas (Figuras 13 e 14) e anālise de outros, da literatura, re ferentes à distribuição de espessura e de litofācies do Subgrupo Itararē INORTHFLEET, MEDEIROS \& MUHLMANN, 1969, Figuras 8, 9 e 10; FULFAR0, 1971, Figura 14.) (Figuras 11, 12, 15 e 16).

Comparando-se os mapas de isōpacas do Subgrupo Itararē mais Formação Aquidauana (NORTHFLEET, MEDEIROS \& MÜHLMANN,op.cit.) (Figura 11) e de desvios da superfície de tendência de 30 grau do Subgrupo Itararē (FULFARO, op cit.)(Figura 12), com os de porcentagem de diamictitos em relação à espessura total da sequência Itararē e o seu respectivo mapa residual (Figuras 13 e 14), verifica-se que as maiores porcentagens de diamictitos estão associados com as āreas tectonicamente negativas, como apontei acima.

Por sua vez, o exame dos mapas de isoporcentagem de areia e de folhelho, do Subgrupo Itararē mais Formação Aquidauana (NORTHFLEET, MEDEIROS \& MUHLMANN, op.cit.)(Figuras 15 e 16), permite constatar o aumento da porcentagem de areias em direção às margens leste, norte e nordeste da Bacia do Pa ranā. Tal situação parece indicar, portanto, que nessas diré ções situavam-se as āreas de proveniēncia principal desses clāsticos. Em contraposição, para sudoeste, hā um predomínio dos folhelhos, sugerindo um eixo principal de acumulação NESo, conforme jā havia sido constatado por FULFARO (1971).

0 quadro paleogeogräfico imaginado, com base nos elementos acima, assemelha-se, atē certo ponto, ao apresenta do por ROCHA-CAMPOS, FARJALLAT \& YOSHIDA (1969b) e FRAKES \& CROWELL (1969, 1972). O centro glacial situava-se a leste da atual borda da Bacia do Paranā e um dos seus lobos, passando 
por uma região de topografia variada, condicionada por depressões do embasamento (vales glaciais?), atingiu o Estado de São Paulo, localizando-se, principalmente, nas āreas mais deprimidas, depositando-se, por vezes, em regiões de influēn cia marinha. A disposição da antiga linha de costa deve ter variado no sentido geral leste-oeste, havendo alguns dados indicativos de sua localização, aproximada, a leste de Araçoiaba da Serra, no tempo correspondente ao limite entre as Microfloras I-II e, pröximo a Gramadinho, no intervalo correspondente à Microflora III (SANTOS, op.cit.).

Pode-se especular, com relação à disposição da fren te glacial, com base na presença do pavimento de clastos, em Jumirim, a $50 \mathrm{~km}$ a $\mathrm{NO}$ da margem atual da Bacia, que o lobo glacial ultrapassou, no seu deslocamento, a citada localidade, podendo ter atingido partes mais interiores da Bacia.

Com relação às ingressões marinhas, a anālise integrada dos mapas das Figuras 15 e 16, sugere que o mar,que in gressou, esporadicamente, na parte marginal do norte da Bacia do Paranā, esteve sempre presente na região sudoeste. Sua conexão com o oceano "aberto" poderia ter sido pela região sugerida por FRAKES \& CROWELL (1969) ou, então, entre o escu do Uruguaiano e o sul do arco de Ponta Grossa, haja vista a alta porcentagem de folhelhos nesta região, mostrada pelo mapa de NORTHFLEET, MEDEIROS \& MÜHLMANN (op. cit.), alguns contendo tambēm Tasmanites (DAEMON \& QUADROS, op. cit.). Ambas as possibilidades encontram fundamento,pois MARTIN, WALLISER \& WILCZEWSKI (1970), jā mencionam a possibilidade de existir, durante o Permo-Carbonifero, um proto-oceano Atlāntico, ao sul da Bacia do Paranā. 


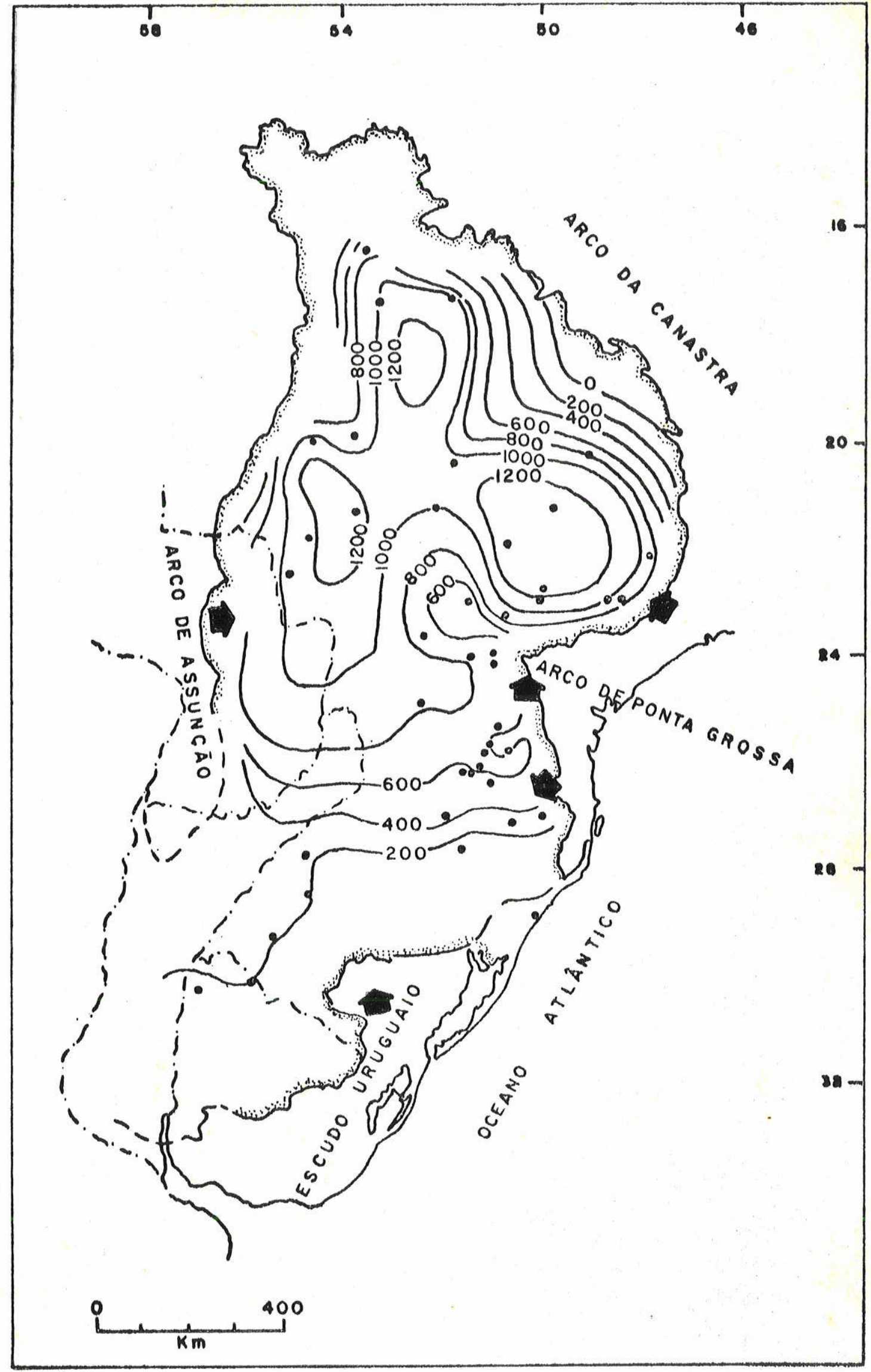

Figura 11 - Mapa de isöpacas da Formação Itararē e Aquidauana (seg. NORTHFLeEt, MEdeiros \& MUHLMANN, 1969). Explicação: intervalo: 200m; pontilhado: limite de afloramento; setas: direções gerais de movimento das geleiras. 


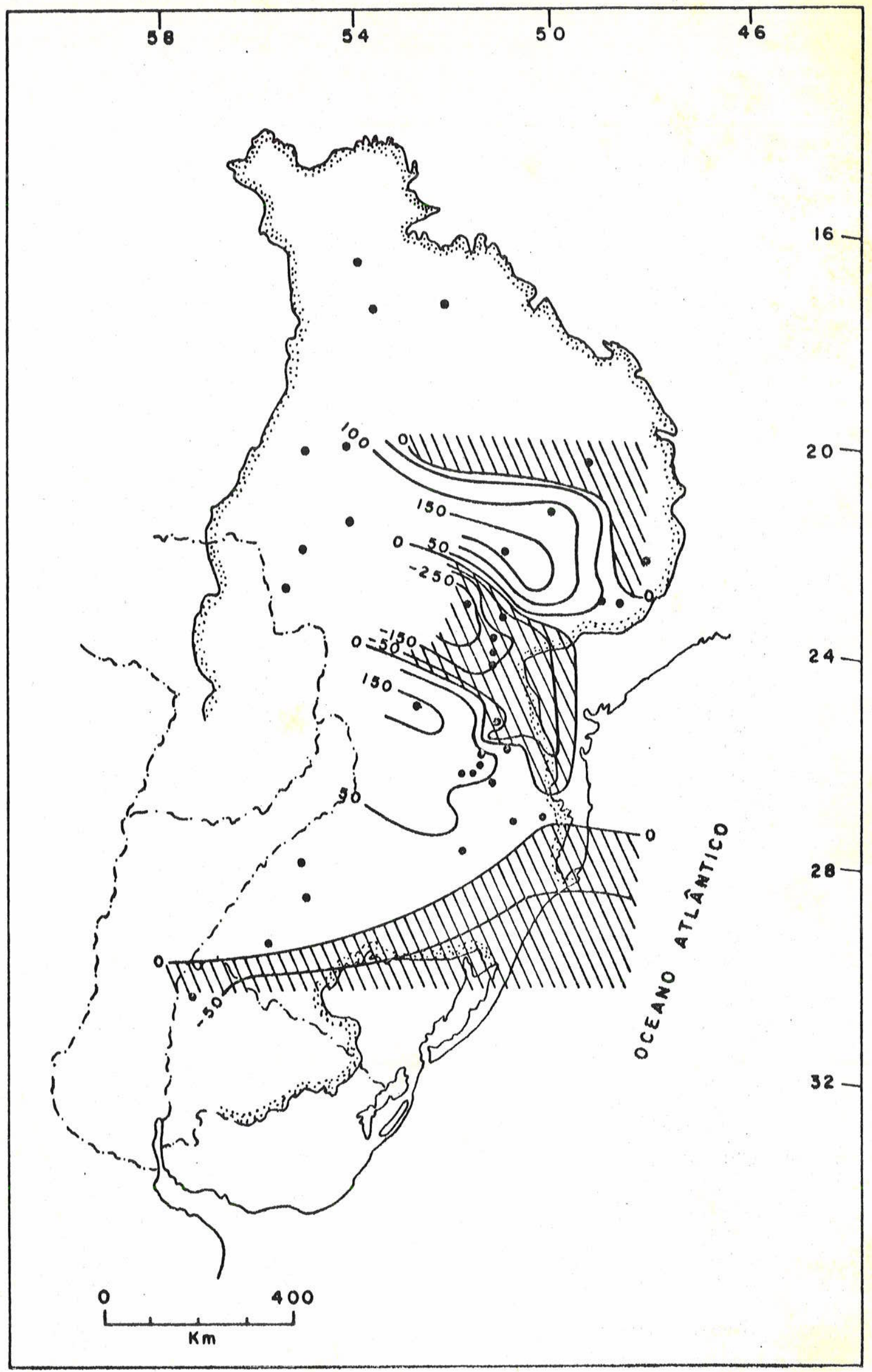

Figura 12 - Mapa de desvios da superfícíe de tendência de 39 grau do subgrupo Itararë (seg. FULFARO, 1971). 


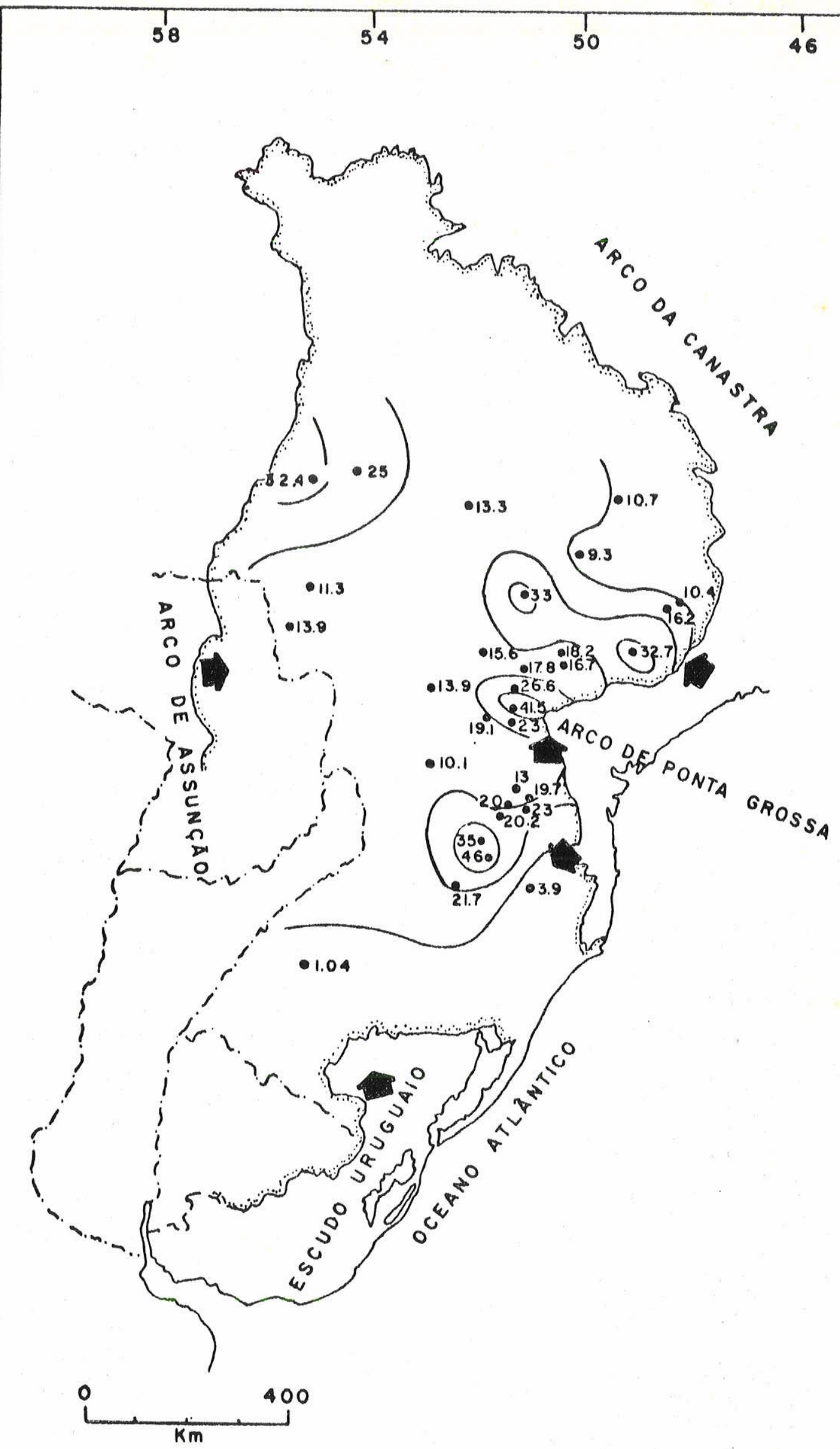

Figura 13 - Mapa de porcentagem de diamictito em relação à espessura total do Subgrupo Itararë, em subsuperficie.Expli caça: intervalo: 10\%; pontilhado: limite de afloramento; setas: direcões gerais de movimento das geleiras. 


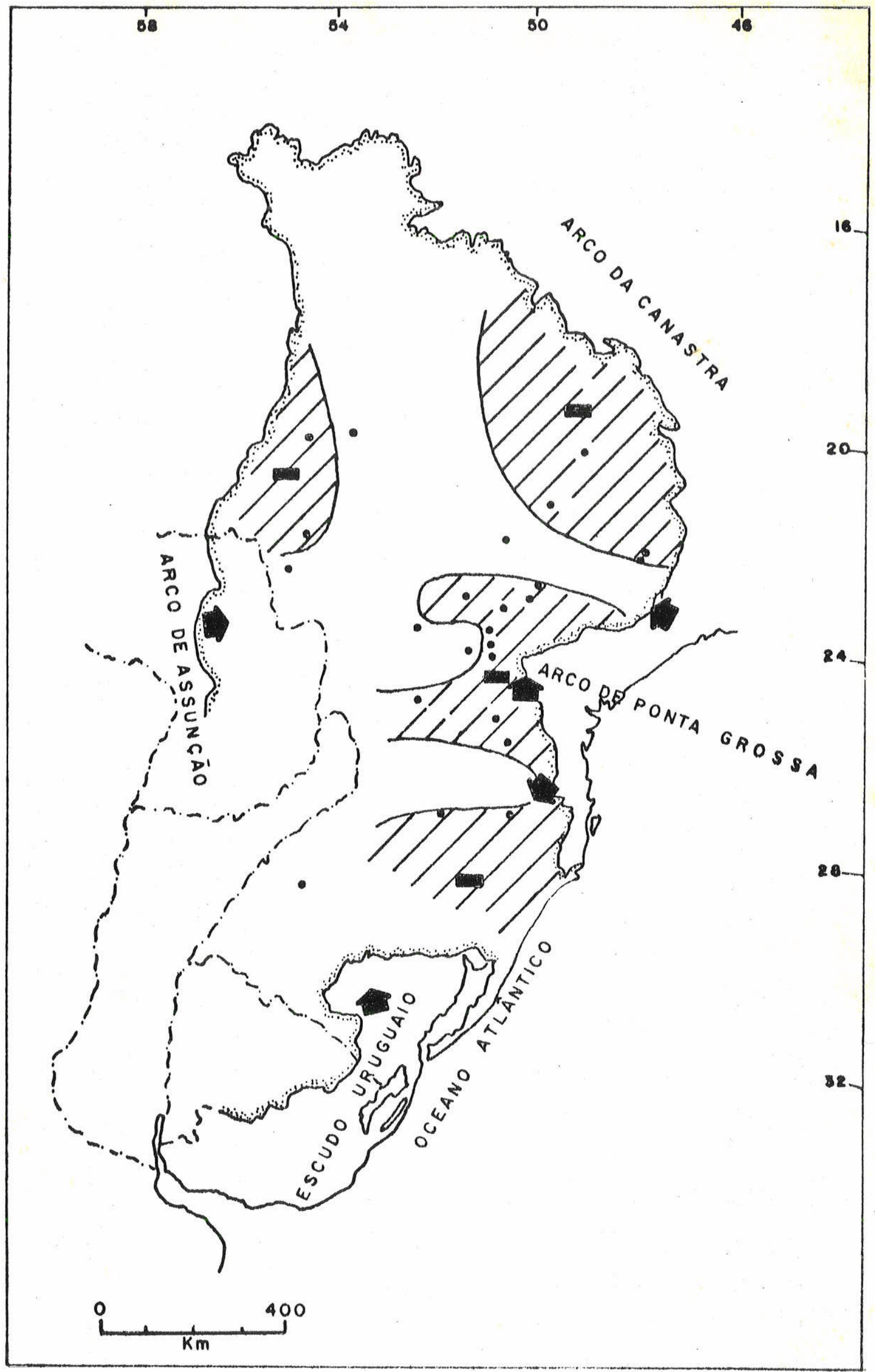

Figura 14 - Mapa de resĩduo da porcentagem de diamictito em relaçāo ä espessura total do Subgrupo Itararē, em subsuper fïcie. Explicação: em branco: äreas tectônicamente mais negativas (desvios positivos); hachurado:äreas tec tōnicamente mais positivas (desvios negativos); pontilhado: limite de afloramento; setas: direções gerais de movimento das geleiras. 


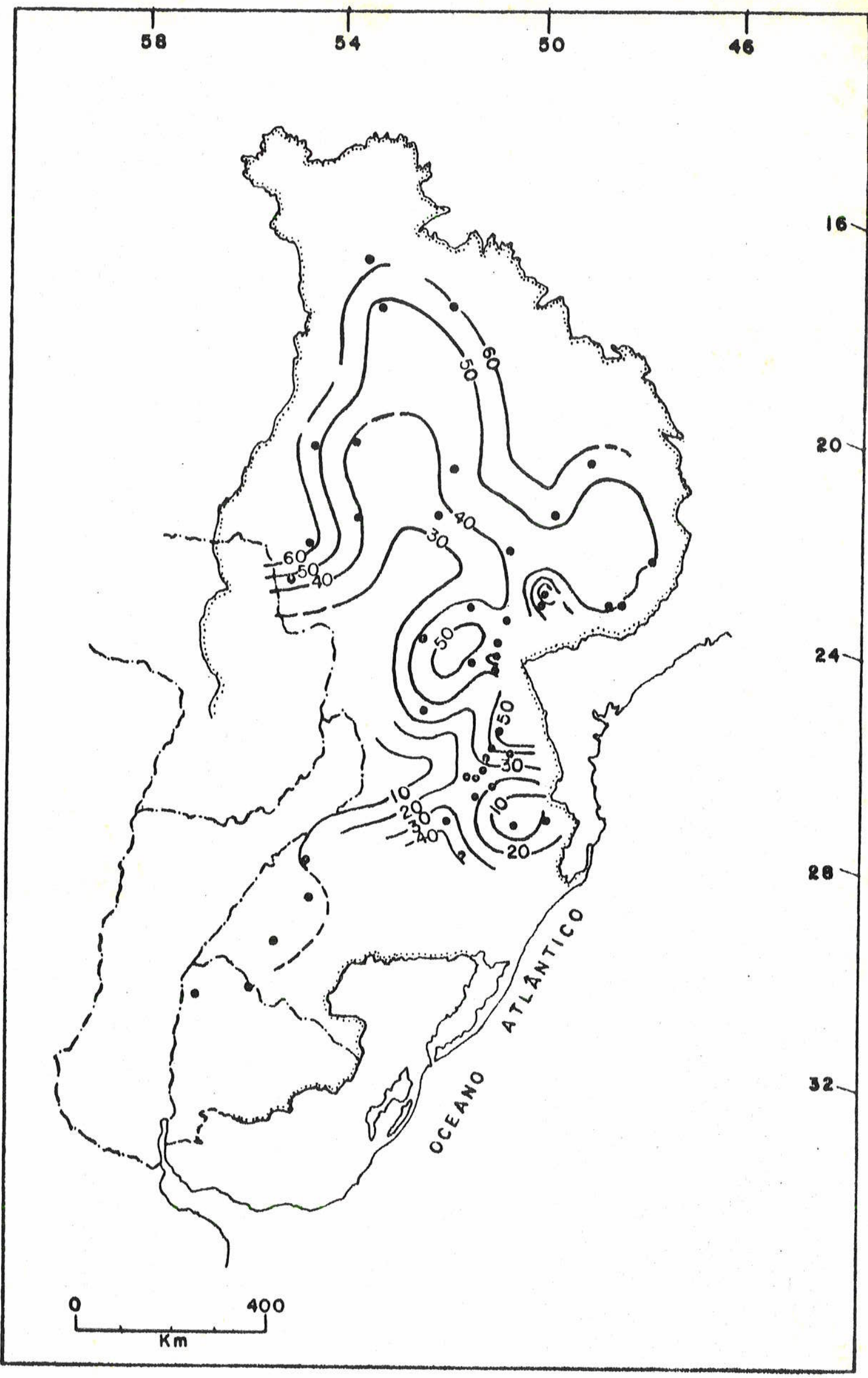
Figura 15 - Mapa de porcentagem de areía na formaçäo Itararé e Aquidauana (seg. NORTHFLEET, MEDEIROS \& MUHLMANN,1969).
ExDlicacão: intervalo: 10\%: pontilhado: limite de afloramento. 


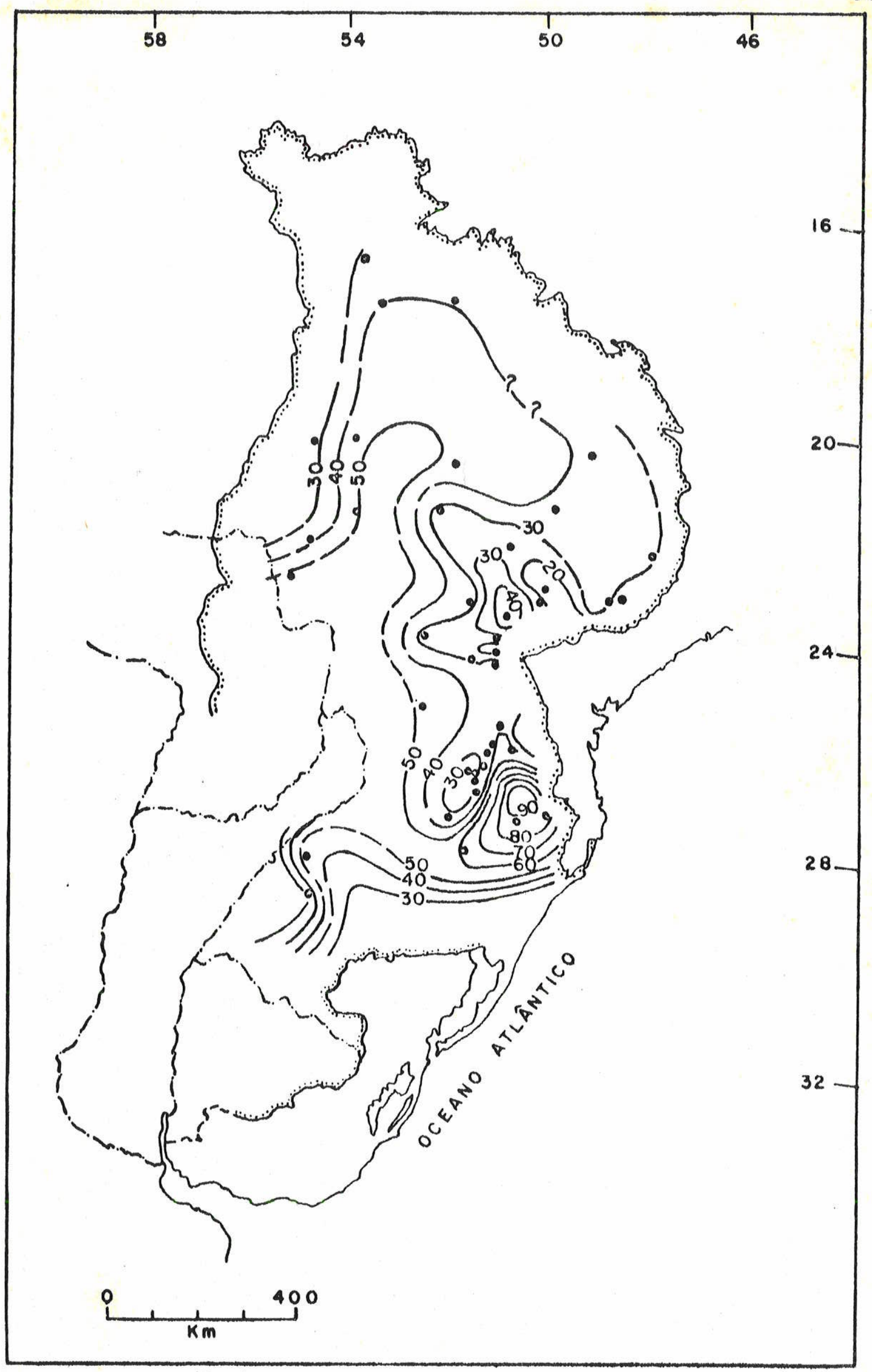

Fijura 16 - Mapa de porcentagem de folhelho na Formação Itararē e Aquidauana (seg. NORTHFLEET, MEDEIROS \& MUHLMANN, 1969). Explicaçäo: intervalo: 10\%; pontilhado: limite de afloramento. 


\section{8 - RESUMO}

A presente dissertação conta os resultados preli minares de um projeto global, que visa o estudo da estrati grafia da faixa oriental de afloramento do Grupo Tubarão em especial do Subgrupo Itararé, tendo por base o levantamento sistemātico de perfis estratigrāficos, aproximadamente, per pendiculares à faixa de afloramentos, ao longo de todas as estradas disponíveis que cruzam a extensa faixa sedimentar.

As āreas inicialmente estudadas referem-se às par tes centro e sul do Estado de São Paulo, por constituirem as regiões clássicas e mais significativas de ocorrência do Subgrupo Itararé, tanto em termos de espessura como, no que tange, a complexidade de sua histōria sedimentar.

Os perfis examinados, em nümero de oito, foram,pos teriormente, transformados em seções colunares, sendo corre lacionados entre si tanto litologicamente, como bioestrati graficamente. 0 datum utilizado, para a correlação, o ūni co disponível no àmbito da pesquisa realizada, foi a base da Formação Tatuỉ.

0 exame do painel litoestratigrāfico, resultante, permitiu reconhecer a existēncia de cinco conjuntos de 1 ito logias no Grupo Tubarão. Esta subdivisão derivou da anāi $\underline{i}$ se da distribuição, tanto na vertical como na horizontal, das litologias clāsticas finas (arenitos finos, siltitos, ritmi tos, argilitos e folhelhos) em relação às clāsticas grossas (arenitos médios a conglomerados) e diamictitos. Sua cate goria litoestratigräfica não estā, ainda, perfeitamente cla ra, podendo, até, corresponder a formações (ou membros), de pendente, obviamente, de trabalhos cartográficos futuros.

Dessa forma, optei por um tratamento informal para designar as associações litolögicas verificadas, denominando-os de 
conjunto.

A partir do inferior, caracterizam-se por:

Conjunto A: clāsticos finos associados a diamictitos e clās ticos grossos, na região centro-leste do Estado. Em direção ao sul predominam diamictitos e clāsticos grossos em relação aos finos;

Conjunto B: maior incidēncia de clásticos finos, ocorrendo, subsidiariamente, diamictitos e clāsticos grossos. Tal ca racterística persiste ao longo de toda a faixa deposicional:

Conjunto C: grande quantidade de clásticos finos associados a diamictitos e clásticos grossos na parte centro-leste, en quanto que em direção ao sul e a nordeste, voltam a predomi nar clásticos grossos e diamictitos, em relação aos termos mais finos;

Conjunto D: mesma situação verificada no conjunto B. Tanto na região centro-leste, como na centro-sul, hā maior incidên cia de clāsticos finos, em relação aos grossos e diamictitos. $\mathrm{Na}$ região nordeste predominam os clásticos grossos sobre os demais termos 1 itolōgicos;

Conjunto E: constituídos de siltitos variegados (principal mente, avermelhados e esverdeados) e arenitos finos.

Do ponto de vista estratigräfico, os quatro conjun tos inferiores correspondem ao subgrupo Itararē, enquanto que o mais superior representa a Formação Tatuí.

0 presente trabalho oferece, ainda, a oportunidade de visualizar a distribuição estratigrāfica das diversas as semblēias fossilifferas conhecidas, das litofäcies a elas as sociadas e das biofácies que thes correspondem. Quanto $\overline{\bar{a}}$ composição das assemblēias faunīsticas e florísticas a dis cussão foi baseada, fundamentalmente, no trabalho de ROCHA-CAMPOS \& RÖSLER (no prelo), variando, somente, o contexto estratigrāfico utilizado. 
Das assembléias faunisticas reconhecidas atē o pre sente no Subgrupo Itararé (Hortolândia, Capivari, Araçoiaba e Itaporanga), três delas associam-se aos conjuntos litológi $\cos B-C$ (Araçoiaba, Hortolândia e Capivari) e uma ao conjun to D (Itaporanga). As informações bioestratigräficas pali nológicas indicam que se tratam de intercalações marinhas, de três idades distintas, associadas, às Microfloras I, II, III. 0 poder de resolução da anālise palinológica, não permite, ainda, entender a correlação entre as ocorréncias fossilífe ras associadas à Microflora II (Hortolândia e Capivari), ten do em vista o grau de pormenores atingido atē o presente na identificação das formas encontradas. Dada a pequena distān cia estratigráfica e geogräfica foram elas consideradas como representando a mesma assemblēia.

Do ponto de vista paleoecológico, os fósseis conhe cidos caracterizam uma biofácies de āguas ražs, ou de platá forma interna (SANTOS, op. cit.). As litofácies associadas são, via de regra, constituídas de siltitos ou lamito sîlti co mal estratificado ou mesmo maciço, que podem estar asso ciados, direta ou indiretamente, a sedimentos de origem gla cial. Estas relações estratigráficas fazem notar que os or ganismos originais viviam, provavelmente, sob condições de águas frias, glaciais, possivelmente, nas proximidades de ca lotas flutuantes (ANDERSON, 1972).

Com relação às assembléias de megafloras, somente, duas são conhecidas, a té o momento, no Subgrupo Itararé, na ārea em estudo. A primeira, em Monte Mōr, associa-se ao con junto litológico $C$, enquanto que a segunda, de Cerquilho, a $\underline{s}$ socia-se ao conjunto D. Em ambos os casos, estão associadas a sedimentos carbonosos, ou mesmo, a camadas finas de carvão.

Para o estudo da microflora, cerca de 200 amostras de litologias diversas foram coletadas ao longo dos perfis examinados. Destas, somente, 70 mostraram-se férteis. 
formas isoladas foram identificadas, preliminarmente, ao ni vel de gēnero, e sua distribuição vertical e geográfica de terminada. A distribuição das formas mais comuns e de am plitude restrita serviu de base para o reconhecimento da constituição das principais microfloras do Subgrupo Itararé, em termos qualitativos e quantitativos.

Três microfloras foram reconhecidas no subgrupo Itararé, a saber:

Microflora I. A microflora mais antiga identificada no Sub grupo Itararē corresponde, litoestratigraficamente, aos con juntos $A-B$.

Caracteriza-se ela, por uma predominância de espo ros, que podem atingir atē $80 \%$ (em média), acompanhados por quantidades subsidiārias de pōlens dos tipos monossacados (atē cerca de 20\%), monocolpados (atē 2-3\%) e bissacados simples e estriados (até cerca de $3 \%$ ).

Microflora II. A Microflora I é sucedida por uma outra as semblēia de carāter transicional, mais diversificada, onde se nota jā um decrēscimo da frequência de esporos, cuja por centagem mēdia baixa até cerca de 5\%\%. Acompanham-nos pōlens monossacados e monocolpados, cuja frequência total è equi valente ao da Microflora I, e bissacados simples e estria dos cujas porcentagens mēdias jā ultrapassam 10\%. Gēneros caracterīsticos e, aparentemente, limitados a este interva 10 correspondem aos esporos Verrucososporites, Microbaculis pora (?), Pustulatisporites, Brochotriletes e pōlens Striatoabietites e Alisporites. Litoestratigraficamente, a assembléia caracteriza o conjunto $C$.

Microflora III. A assemblēia, estratigraficamente, mais jovem do Subgrupo Itararé, correspondente ao conjunto D, exi be um decréscimo acentuado da porcentagem de esporos $<<50 \%$, em média) e de bissacados simples, em relação à anterior. De outro lado, os bissacados estriados, aparecem com frequén 
cia elevadas (mēdia de cerca de $30 \%$ ). A porcentagem de mo nossacados baixa, ligeiramente, enquanto o contrārio sucede com os pōlens monocolpados. A presença de formas atribuĩ veis às Tasmanales, constitui uma feição notāvel da assem bléia, da qual podem perfazer pouco mais de $5 \%$.

Alēm de Tasmanites, esporos dos gēneros Cyclogra nusporites, Lycospora, parecem ser privativas deste interva 10, juntamente com pölens atribuíveis a Hamiapolzenites.

Com relação à idade do Subgrupo Itararē, os dados bioestratigráficos disponīveis, especialmente os palinolōgi cos, indicam que esta situa-se no intervalo neocarboníferoeo (meso) permiano. Os dados bioestratigräficos indicam, tam bēm, que, pelo menos, em um caso (entre os conjuntos B-C), o limite entre os conjuntos litológicos reconhecidos coincide, aproximadamente, com o limite bioestratigräfico entre as mi crofloras neles contidos, o que constitui evidência em apoio à utilidade prática do seu reconhecimento.

Apesar da complexidade do arranjo espacial das $1 \underline{i}$ tologias do Grupo Tubarão, particularmente a do Subgrupo I ta raré, e o ainda precārio controle bioestratigrāfico disponī vel, foi possivel atingir-se algumas inferéncias gerais quan to à histōria tecto-sedimentar e paleogeogrāfica do Grupo, na parte norte da Bacia do Paranā.

Levando-se em conta as características litológicas e texturais gerais dos conjuntos litolögicos reconhecidos,pa rece evidente que a histōria tecto-sedimentar do Grupo Tuba rão, no Estado de São Paulo, envolveu, pelo menos, quatro fá ses distintas.

A primeira abrange desde a época prēvia à deposi ção do conjunto $A$, atē o final da deposição do conjunto B.C racteriza-se, inicialmente, por um período de intensa ati vidade tectōnica, principalmente, na região centro-sul. Ao que tudo indica, o inīcio da sedimentação do Grupo Tubarão 
ocorreu sobre um embasamento de topografia irregular, com re giões intrabassinais deprimidas de orientação geral SE-NO (vale do rio Tietē, região de Itararé e, localmente, a re gião de Sorocaba) e elevadas (região de Capão Bonito e Soro caba e ao norte de Campinas), que se estendiam, ao que pare ce, até a região marginal atual da Bacia. Tais feições fo ram responsāveis, em parte, pela variação lateral de fācies verificada no conjunto inferior, ao longo da direção depos $\underline{i}$ cional.

Apōs a deposição do conjunto A, a sub-bacia norte parece ter alcançado um período de relativa calma tectônica, fazendo com que, fenōmenos isostāticos, relacionados ao meca nismo de avanço e recuo das geleiras, presentes desde o iní cio da sedimentação, tornem-se, relativamente, predominantes. Is to pode ser evidenciado pelas características texturais do conjunto $B$ e pelo registro de algumas intercalações marinhas.

A segunda fase, abrangendo parte do conjunto C, ca racteriza-se pelo recrudescimento de condições tectōnicas. Nesta época, provavelmente, teve início um levantamento gra dual da borda nordeste da Bacia, que se manteve até o final da deposição do Subgrupo. No geral, a sedimentação é consti tuĩda de clásticos grossos e diamictitos, notadamente, nas regiões centro-sul e nordeste.

$\mathrm{Na}$ terceira fase, verifica-se a deposição da parte superior da sequéncia Itararé (conjunto D), predominando, na região nordeste, sedimentação nitidamente continental, gra dando, em direção ao sul, para condições de maior afluência marinha. Texturalmente, os sedimentos a nordeste são gros sos, enquanto que, nas regiões centro-leste e centro-sul,são, predominantemente, constituídos de clásticos finos.

Finalmente, a quarta e ūitima fase representada, estratigraficamente, pela Formação Tatuỉ, corresponde a um pe rīodo tectonicamente calmo, haja vista a sedimentação extremą 
mente fina e homogênea dessa sequéncia. 0 início do ciclo pós-glacial pode ter sido erosional (SOARES, 1972), com re trabalhamento do material depositado no ciclo anterior.

No que tange $\bar{a}$ paleogeografia, as reconstitui ções disponīveis dos depōsitos glaciais do Subgrupo Itararé, fundamentaram-se, principalmente, em dois tipos de evidēn cias: a) dados relativos à direção do movimento do gelo, de terminados a partir de elementos direcionais verificados nas rochas ou no seu embasamento; e b) natureza das fácies sedi mentares e sua distribuição.

0 quadro paleogeográfico imaginado, com base nos elementos acima, assemelha-se, até certo ponto, ao apresenta do por ROCHA-CAMPOS, FARJALLAT \& YOSHIDA (1969b) e FRAKES \& CROWELL (1969, 1972). O centro glacial sịtuava-se a leste da atual borda da Bacia do Paranā e um dos seus lobos

(Kaokeveld), passando por uma região montanhosa, atingiu o Estado de São Paulo, localizando-se, principalmente, nas āreas mais deprimidas, depositando-se, por vezes, em regiões marinhas, conforme ē atestado pela ocorrēncia de Tasmanites, em diamictitos, da localidade de Gramadinho.

Pode-se especular, com relação à disposição da frente glacial, com base na presença do pavimento de clastos, em Jumirim, a $50 \mathrm{~km}$ a $N 0$ da margem atual da Bacia, que o 10 bo glacial ultrapassou, no seu deslocamento, a citada locali dade, podendo ter atingido partes mais interiores da Bacia.

Com relação às ingressões marinhas, a anālise in tegrada dos mapas de isoporcentagem de areia e folhelho, da Formação Itararē mais Formação Aquidauana (NORTHFLEET, MEDEI ROS \& MUHLMANN, 1969), sugere que o mar que ingressou, espó radicamente, na parte marginal do norte da Bacia do Paranā esteve sempre presente na região sudoeste. Sua conexão com - oceano "aberto" poderia ter sido atravēs das regiões en tre o escudo Uruguaio-Rio Grandense e o arco Martin Garcia 
(FRAKES \& CROWELL, 1969), ou entre o escudo Uruguaiano e o sul do arco de Ponta Grossa, tendo em vista a alta porcenta gem de follhelhos nesta região, mostrada pelo mapa de NORTHFLEET, MEDEIROS \& MUHLMANN (op. cit.), alguns contendo, tambēm, Tas manites (DAEMON \& QUADROS, 1970). Ambas as possibilidades encontram fundamento, pois MARTIN, WALLISER \& WILCZEWSKI (1970) jā mencionam a possibilidade de existir, durante o Permo-Carbonīfero, um proto-oceano Atlāntico, ao sul da Ba cia do Paranā. 


\section{BIBLIOGRAFIA}

ALMEIDA, F.F.M. de - 1948 - A "Roche Moutonnēe" de Salto,E tado de São Paulo. Geol. e Metal.,Bol.nọ 5,pp.112118.

ALMEIDA, F.F.M. de - 1954 - Geologia do Centro-Leste Matogrossense: Brasil. Div.Geol.Miner., Bol. nọ 150.

ALMEIDA, F.F.M. de - 1956 - In "Relatōrio Anual do Diretor, Ano de 1956". Div.Geol.Miner., pp.87-92.

AMARAL, S.E. do - 1965 - Nova ocorrência de "Roche Moutonnēe" em Salto, São Paulo. Bol.Soc.Bras.Geol., vol. 14, nos 1-2, pp.71-82.

ANDERSON, J.B. - 1972 - The marine geology of the Wedde11 Sea. Tese de doutoramento, Florida State University, Tallahassee, Florida (inédita).

ANDRADE, S.M. \& SOARES, P.C. - 1970 - Geologia de semi-deta The do Centro-Leste do Paranā. Petrobrās, Desul, Re1.nQ400 (inēdito).

ANDRADE, S.M. \& SOARES, P.C. - 1971 - Geologia do CentroLeste do Estado de São Paulo. Petrobrās,Desul, Rel. nọ 407 (inēdito).

ARCHANGELSKY, S. - 1971 - Las tafofloras del Sistema Paganzo en la Republica Argentina. An.Acad.Bras. Ciēn., vol. 43, Suplemento, pp.67-88.

BARBOSA, 0. \& ALMEIDA, F.F.M.de - 1949a - A Sērie Tubarão na Bacia do Rio Tietê, Estado de São Paulo. Div. Geol.Miner., Notas Prels.Est., nọ 48.

BARBOSA, 0. \& ALMEIDA, F.F.M.de - 1949b - Nota sobre a es tratigrafia da Série Tubarão, no Estado de São Pau 10. An.Acad.Bras.Ciên., vo1.21, nọ 1, pp.65-68.

BARBOSA, 0. \& GOMES, F.de A. - 1958 - Pesquisa de petróleo na Bacia do Rio Corumbataí, Estado de São Paulo. Div.Geol.Miner., Bol. nọ 171. 
BOLLTON, G.S. - 1972 - Modern Artic glaciers as depositional models for former ice sheets. Jl.Geol.Soc. Lond., vol. 128, pp. 361-393.

BJYRNBERG, A.J.S.; LANDIM, P.M.B. \& GANDOLFI, N. - 1965 - In dĩcios de contribuição eōlica nos sedimentos do Grü po Tubarão, em Limeira e Casa Branca, São Paulo. Bol.Esc.Eng.São Carlos, USP, Geologia nọ 13.

CAREY, S.W. \& AHMAD, N. - 1961 - Glacial marine sedimentation. In G.0.Ransch (Ed.), Geology of the Artic,vol. 2, pp. 805-897, Univ. Toronto Press.

DAEMON, R.F. \& QUADROS, L.P. - 1970 - Bioestratigrafia do Neopaleozóico da Bacia do Paranā. An. XxIV Congr. Bras.Geol., pp. 359-412.

DAMASCENO, E.C. - 1973 - Pesquisa de algumas matērias primas para agregados leves. Tese de Livre Docência, Esc. Politēcnica, USP (inēdita).

DAVINo, A. - 1975 - Geologia da Serra de Araçoiaba,Estado de São Paulo. Bol. IG, USP, vol. 6, pp. 129-144.

DOLIANITI, E. \& MILLAN, J.H. - 1972 - Novo afloramento de ve getais gondwânicos no Estado de São Paulo. An.Acad. Bras.Ciên., vol. 45, pp. 653-654.

EVANS, P.R. - 1969 - Upper Carboniferous and Permian palynological stages and their distribution in eastern Australia. Gondwana Stratigraphy, vol. 2, UNESCO, Pa ris, pp. 41-54.

FAEGRI, K. \& IVERSEN, J. - 1966 - Textbook of pollen analysis. Hafner Publishing Co., New York, 237 p.

FARJALLAT, J.E.S. - 1970 - Diamictitos Neopaleozóicos e sedi mentos associados do sul de Mato Grosso. Div. Geol. Miner., Bol. no 250.

FIORI, A.P. - 1977 - Estratigrafia do Grupo Tubarão (Formação Aquidauana) na região sudoeste do Estado de Minas Gerais. Dissertação de Mestrado, Inst. de Geociências, USP (inédita). 
FLINT, R.F.; SANDERS, J.E. \& RODGERS, J. - 1960 - Diamictite a substitute term for symmictite. Bull. Geol. Soc. America, vol. 71, no 12, p. 1809.

FRAKES, L.A. \& FIGUEIREDO FILHO, P.M. de - 1967 - Glacial ro cks of the Paranā Basin exposed along the SorocabaItapetininga road. In J.J.Bigarella, R.D. Becker e I.D.Pinto (Eds.), Problems in Brazilian Gondwana Geology, pp. 103-106, Curitiba.

FRAKES, L.A.; FIGUEIREDO FILHO, P.M. de \& FULFARO, V.J.-1968Possible fossil eskers and associated features of the Paranā Basin, Brazil. Jour.Sed.Petrol., vol.38, no 1, pp. 5-12.

FRAKES, L.A. \& CROWELL, J.C. - 1969 - Late Paleozoic glaciation: I South America. Bull. Geol. Soc.America,vol. 80, no 6, pp. 1007-1042.

FRAKES, L.A. \& CROWELL, J.C. - 1972 - Late Paleozoic glacial geography between the Paraná Basin and the Andean Geosyncline. An. Acad.Bras.Ciēnc.,vol. 44, Suplemento, pp. 139-145.

FULFARO, V.J. - 1971 - A evolução tectônica e paleogeogrāfica da Bacia Sedimentar do Paranā pelo "Trend Surface Analysis". Bol.Esc.Eng.São Carlos, USP, Geologia nọ 14 .

FULFAR0, V.J. - 1974 - Tectônica do alinhamento estrutural do Paranapanema. Bol. IG, USP, vol. 5, pp. 129-138.

FULFARO, V.J. \& LANDIM, P.M.B. - 1976 - Stratigraphic Sequen ces of the intracratonic Paranā Basin. News1.Stratigr., vol. 4, no 3, pp. 150-168.

KEMP, E.M. - 1973 - The palynology of Late Paleozoic glacial deposits of gondwanaland.In Campbell K.S.W. (Ed.), Gondwana Geology, Austr. Nat. Univ. Press, Canberra, pp. 397-413.

LANDIM, P.M.B. - 1970 - Contribuição ao estudo dos mistitos do Grupo Tubarão no Estado de São Paulo. Tese de Li vre-Docência, Fac.Fil.Ciênc.Letr.Rio Claro(inēdita). 
LANDIM, P.M.B. - 1971 - Aplicações de matrizes de probabilidade de transição litológica a seções estratigrāfi cas do Grupo Tubarão. An.do XXV Congr.Bras. Geol., pp. 281-293.

LANDIM, P.M.B. - 1972 - Upper Paleozoic glaciation in the Northeastern Paranā Basin, Brazil (Tubarão Group). $24^{\text {th }}$ Int.Geol.Congress., Montreal, Section 6, pp. 406-414.

LANDIM, P.M.B. \& BARROS, M.B.R. - 1972 - Distinção de tilitos dentre os mistitos do Subgrupo Itararé.Rev. da Soc.Bras.Geol., vol. 2, no 4, pp. 270-274.

LEINZ, V. - 1937 - Estudos sobre a glaciação permo-carbonífera do sul do Brasil. Dep.Nac.Prod.Miner.,Div.Fom. Prod. Miner., Bol. no 21.

LEINZ, V. - 1940 - Petrologia das jazidas de apatita de Ipanema (Estado de São Paulo). Dep.Nac.Prod.Minr.,Div. Fom.Prod.Miner., Bol. no 40.

LIMA, M.R. de; SAAD, A.R.; CARVALHO, R.G. de \& SANTOS, P. R. dos - no prelo - Foraminíferos arenáceos e outros fósseis do Subgrupo Itararé (Neopaleozōico) da Bacia do Paranā. Brasil. An.XXIX Congr.Bras.Geol.,Be10 Horizonte.

MARTIN, H. - 1961 - The hypothesis of continental drift in the light of recent advances of geological knowledge in Brazil and in South West Africa. Geol.Soc. South Africa, 64 (Annex), pp. 1-47.

MARTIN, H.; WALLISER, 0.H. \& WILCZEWSKI, N. - 1970 - A Gonia tite from the glacio-marine Dwyka beds near Schlip, South West Africa.Proc. and Papers, $2 \frac{\text { nd }}{\text { Int. Gondwa- }}$ na Symposium, South Africa, 1970,pp.621-626.

MEdEIROS, R.A. \& TOMAZ FILHO, A. - 1973 - Fäcies e ambientes deposicionais da Formação Rio Bonito. An. XXVII Congr. Bras. Geol., vol. 3, pp. 3-12.

MENDES, J.C. - 1952 - Fāunula permo-carbonīfera marinha de Capivari. Bol.Fac.Fil.Ciēnc.Letr., USP, nọ 134, Geologia no 7. 
MEZZALIRA, S. - 1956 - Novas ocorrēncias de camadas marinhas permo-carboniferas no Estado de São Paulo. Bol.Soc. Bras. Geo1., vol. 5, no 1, pp. 61-67.

MILLAN, J.H. - 1972 - Macrofiōrula carbonīfera de Monte Mor, Estado de São Paulo. Tese de Doutoramento do IG,USP ( inēdita).

MILLAN, J.H. - 1974 - Sobre as coniferopsida da flōrula gond wānica de Monte Mor, Estado de São Paulo, Brasil. Ameghiniana, vo1. 11, no 2, pp. 124-134.

MILLAN, J.H. - 1975 - Tafoflörula Monte Mor do Estado de São Paulo: seus elementos e seu significado no Gondwana Inferior do Brasil. Rev.Soc.Bras.Geociēnc., vol. 5, n! 1, pp. 1-14.

NORTHFLEET, A.A.; MEDEIROS, R.A. \& MUlHMANN, H. - 1969 - Rea valiação dos dados geológicos da Bacia do Paranā. Bol. Tecn. Petrobrās, vol. 12, nọ 3, pp. 291-346.

PACHECO, J.C. - 1927 - Relatōrio elucidativo do esbôço geolō gico da região compreendida entre o meridiano $4^{\circ}$, rio Itararé e os paralelos $23^{\circ} 24^{\prime}$ e $24^{\circ} 38^{\prime}$. Rel.Com. Geogr. Geo1., pp. 9-12.

PADULA, E. \& MINGRAM, A. - 1967 - Subsurface Carboniferous beds of the Chaco-Mesopotamian region, Argentina and their relatives in Uruguay, Paraguay and Brazil. Gondwana Stratigraphy, IUGS Symposium, Buenos Aires, pp. 1025-1040.

PASCHOLATI, E.M. \& PACCA, I.G. - no prelo - Estudo paleomagnētico de secções do Subgrupo Itararē. An. XXIX Congr. Bras. Geol., Belo Horizonte.

PETRI, S. - 1964 - Grupo Tubarão. In Geologia do Estado de São Paulo. Bol. Inst.Geogr.Geol., nọ 41, pp. 56-63.

PETRI, S. \& FULFARO, V.J. - 1967 - Considerações geolōgicas sōbre a região de Itapeva, São Paulo.Bol.Soc. Bras. Geo1., vol. 16, nọ 1, pp. 25-40.

PETTIJOHN, F.J. - 1957 - Sedimentary rocks(2 - Ed.), Harpers and Bros, New York, $690 \mathrm{p}$. 
POTTER, P.E. \& PETTIJOHN, F.J. - 1963 - Paleocurrents and Ba sin Analysis. Springer-Verlag, Berlim, $296 \mathrm{p}$.

RIGBY, J.F. - 1970 - The distribution of Lower Gondwana plan ts in the Paraná Basin of Brazil. Proc.and Papers, 2 nd Int. Gondwana Symposium, South Africa, 1970,pp. $575-584$.

RIGBY, J.F. - 1973 - Gondwanidium and other similar Upper Pa leozoic genera and their stratigraphic significance. Geol. Surv. Q1d. Públ., no 350, Palaeont. Papers, no 24.

REINECK, H.E. \& SINGH, J.B. - 1973 -Depositional Sedimentary Environments. Springer-Verlag, Berlin, $412 \mathrm{p}$.

ROCHA-CAMPOS, A.C. - 1963 - Deformações penecontemporâneas em sedimentos glácio-1acustres do Grupo Tubarão.Bol. Soc. Bras. Geol., vol.12, nos. 1-2, pp.49-56.

ROCHA-CAMPOS, A.C. - 1966 - Novas ocorrências de fósseis marinhos no Grupo Tubarão em São Paulo e Santa Catari na. Bol.Soc.Bras.Geol., vol. 15, nọ 4, pp. 5-12.

ROCHA-CAMPOS, A.C. - 1967 - The Tubarão Group in the Brazilian portion of the Paranā Basin. In J.J.Bigarella, R.D.Becker e I.D.Pinto (Eds.), Problems in Brazilian Gondwana Geology, pp. 27-109, Curitiba.

ROCHA-CAMPOS, A.C. - 1970 - Upper Paleozoic bivalves and gas tropods of Brazil and Argentina, a review.Proc. and Papers, $2 \stackrel{\text { nd }}{ }$ Gondwana Symposium, South Africa, pp. 605-612.

ROCHA-CAMPOS, A.C. - 1974 - Carvão de pedra no Estado de São Paulo: Situação atual e perspectivas. Rel. Secret. Planej. do Estado de São Paulo (inēdito).

ROCHA-CAMPOS, A.C.; FARJALLAT, J.E.S. \& YOSHIDA, R. - 1968 New glacial features of the Upper Paleozoic Itarare Subgroup in the State of São Paulo, Brazil.Bol.Soc. Bras.Geo1., vo1.17, no 1, pp. 47-57.

ROCHA-CAMPOS, A.C.; FARJALLAT, J.E.S. \& YOSHIDA, R. - 1969aCrescentic marks on a Late Paleozoic glacial pavement in Southeastern Brazil.Bull.Geol.Soc. America, vol. 80, no $6, p p .1123-1126$. 
ROCHA-CAMPOS, A.C.; FARJALLAT, J.E.S. \& YOSHIDA, R. - 1969bFācies e paleogeografia do Subgrupo Itararē na Bacia do Paranā. An.Acad.Bras.Ciênc., vol.4, nọ 2,pp. 211-213.

ROCHA-CAMPOS, A.C.; SANTOS, P.R. dos \& SAAD, A.R. - 1972 Roadlog São Paulo to Sorocaba. In Excursion GuideBook, Int.Symp. Carboniferous and Permian Systems in South America, São Paulo, pp. 20-29.

ROCHA-CAMPOS, A.C.; OLIVEIRA, M.E.C.B. de; SANTOS, P.R. dos \& SAAD, A.R. - 1976 - Boulder pavements and the sen se of movement of Late Paleozoic glaciers in central eastern São Paulo State, Paranā Basin, Brazil. Bol.IG, USP, vol. 7, pp. 149-160.

ROCHA-CAMPOS, A.C. \& ROSLER, 0. - no prelo - Late Paleozoic faunal and floral sucessions in the Paraná Basin, Southeastern Brazil. Proceedings, VIII Int. Congr. Carboniferous Geo1. \& Strat., Moscou, 1975. ROCHA-CAMPOS, A.C.; SAAD, A.R.; SANTOS, P.R. dOS \& OLIVEIRA, M.E.C.B.de -no prelo- Algumas feições periglaciais do Subgrupo Itararé no Estado de São Paulo. Bol.IG, USP.

ROSLER, 0. - 1972 - Flora da Formação Rio Bonito do Estado do Paranā. Tese de Doutoramento, IG, USP, (inēdita). ROSLER, 0. - 1973 - Tafofloras Neopaleozöicas da Bacia do Pa ranā. 20 Congr. Latinoamericano Geo1., Caracas, Res. Com., p. 32 .

RÖSLER, 0. - no prelo - Fossil plants and the problem of the Carboniferous-Permian boundary in the Brasilian Eogondwanic sequence. Bol. IG, USP.

RUNNEGAR, B. - 1972 - Late Paleozoic Bivalvia from South Ame rica: provincial affinites and age. An. Acad. Bras. Ciēnc., vol.44, Suplemento, pp. 259-312.

SANFORD, R.M. \& LANGE, F.W. - 1960 - Basin study approach to oil evaculation of Paranā miogeosyncline South Brazi1. Amer.Assoc.Petro1.Geo1.,Bu11.44, nọ8,pp.13161370 . 
SANTOS, P.R. dos - em preparação - Distribuição, caracterís ticas e fācies de diamictitos do Subgrupo Itararé, no centro e sul do Estado de São Paulo. Dissertação de Mestrado, IG, USP.

SANTOS, P.R. dos; SAAD, A.R.; CARVALHO, R.G. do \& LIMA,M.R. de - 1973 - Intercalações marinhas na sequência glacial neopaleozöica (Subgrupo Itararé), da parte norte da Bacia do Paranā, Brasil. 20 Congr. Latino americano Geol., Caracas, Res. Com., pp. 219-220.

SCHNEIDER, R.L.; MÜLHMANN, H.; TOMMASI, E.; MEDEIROS, R.A.; DAEMON, R.F. \& NOGUEIRA, A.A. - 1974 - Revisão estratigrāfica da Bacia do Paranā. An.XXVIII Congr. Bras.Geo1., vol. 1, pp. 41-65.

SEGROVES, K.L. - 1970 - The sequence of palynological assem blages in the Permian of the Perth Basin, Western Australia. Proc.and Papers, 2 nd Gondwana Symposium, South Africa, pp. 511-529.

SMITH, W.S.T. - 1925 - An Apparent - Dip.Protractor. Econ. Geol., vol. 20, pp. 181-184.

SOARES, P.C. - 1972 - 0 limite glacial/pōs-glacial do Grupo Tubarão no Estado de São Paulo. An.Acad.Bras.Ciēnc., vol. 44, Suplemento, pp. 333-342.

SOARES, P.C. \& LANDIM, P.M.B. - 1973 - Aspectos regionais da estratigrafia da Bacia do Paranā no seu flanco nordeste. An.XXVII Congr.Bras.Geol., vol. 1,pp.243256.

SOARES, P.C.; SINELLI, 0.; PENALVA, F.; WERNICK, E.; SOUZA, A. \& CASTRO, P.R.M. - 1973 - Geologia do nordeste do Estado de São Paulo. An. XXVII Congr. Bras. Geol., vol. 1, pp. 209-228.

SOARES, P.C.; LANDIM, P.M.B.; SINELLI, 0.; WERNICK, E.; WU, FU-TAI \& FIORI, A.P. - no prelo - Associações lito lögicas do Subgrupo Itararē e sua interpretação ambiental. Bol.Soc.Bras.de Geol. 
SUGUI0, K. - 1973 - Introdução à Sedimentologia. Edit. Blücher, Ed. da USP, $317 \mathrm{p}$.

TOMMASI, E. - 1973 - Geologia do flanco sudeste da Bacia do Paranā, Rio Grande do Sul, Santa Catarina e Paranā. An. XXVII Congr. Bras.Geol., vol.3, pp.179-188.

VIEIRA, A.J. - 1973 - Geologia do centro e nordeste do Para nā e centro-sul de São Paulo. An. XXVII Congr.Bras. Geol., vol. 3, pp. 259-278.

WASHBURNE, C.W. - 1930 - Petroleum geology of the State of São Paulo. Bol. Com. Geogr. Geol., no 22.

WENTWORTH, C.K. - 1922 - A scale of grade and class terms for clastic sediments. Jour. of Geology, vol.30,n? 2, pp. 377-392.

WENTWORTH, C.K. - 1936 - An analysis of the shapes of glacial cobbles. Jour.Sed.Petr., vol.6, no 2,pp.85-96. 




